\title{
COMPETITIVIDADE DO SISTEMA AGROINDUSTRIAL SUINÍCOLA BRASILEIRO
}

\section{RICARDO COTTA FERREIRA}

Economista

Orientador: Prof. Dr. PEDRO VALENTIM MARQUES

Dissertação apresentada à Escola Superior de Agricultura "Luiz de Queiroz", Universidade de São Paulo, para obtenção do título de Mestre em Ciências, Área de Concentração: Economia Aplicada.

P I R A C I C A B A

Estado de São Paulo - Brasil

Julho de 1998 
Dados Internacionais de Catalogação na Publicação (CIP) DIVISÃO DE BIBLIOTECA E DOCUMENTAÇÃO - Campus "Luiz de Queiroz"/USP

Ferreira, Ricardo Cotta Competitividade do sistema agroindustrial suinicola brasileiro / Ricardo Cotta Ferreira. - - Piracicaba, 1998. 109 p.

Dissertação (mestrado) - E Escola Superior de Agricultura Luiz de Queiroz, 1998. Bibliografia.

1. Agribusiness 2. Carne suina 3. Comercialização agricola 4. Indústria agricola 5. Suinocultura I. Titulo

CDD 338.1 


\section{Dedicatória}

Seria uma grande injustiça de minha parte se não fizesse esta dedicação às pessoas que mais me apoiaram não somente neste trabalho, mas em tudo que faço na vida.

Meus pais, João Ribeiro e Maria Carmen. 


\section{Agradecimentos}

Ao Prof. Pedro Valentim Marques, não somente pela orientação, mas pela paciência e amizade, não medindo trabalho nem esforço para que pudesse contribuir com mais esta realização da minha vida.

Aos professores Marcos Jank e Paulo Furquim por contribuírem com comentários e sugestões às quais foram essenciais para a elaboração desta dissertação e que tenho orgulho de terem aceito o convite de participação nesta banca.

Aos demais professores do Departamento de Economia e Sociologia Rural da ESALQ, representado pela pessoa do Prof. Geraldo Barros. Devo a estes mestres grande admiração e agradeço por terem contribuído para a minha formação técnica e profissional.

À CAPES, CNPq e FAPESP, esperando que este trabalho possa, de alguma maneira, retribuir ao apoio financeiro que estas instituições me deram.

Aos primeiros e eternos amigos de Piracicaba; Murilo, Sérgio, Luiz Cláudio e Bia, Leonardo, Maurício, Estevão, Valter, Paulo e ao responsável por toda esta façanha, Leandro.

Aos funcionários do DESR e à paciência da Maielle, Lu e Cris.

Finalmente, aos grandes amigos:

Em especial, ao Caio, pela experiência e acolhida em sua residência durante o período de cursos na FEA, a quem sou muito grato. Ao Márcio pelo apoio em informática e ao Pedro pelo auxílio no AutoCAD. 


\section{SUMÁRIO}

Página

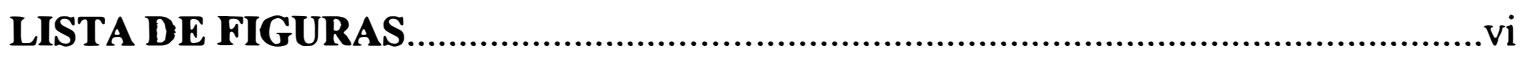

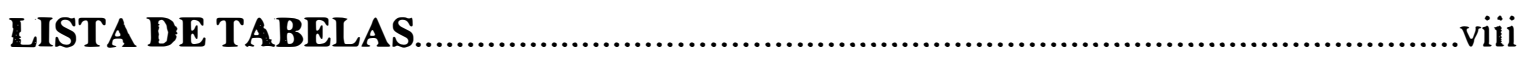

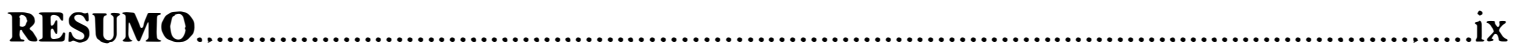

SUMMARY

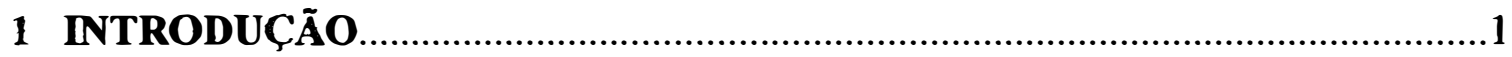

1.1 Importância e problemática.................................................................................

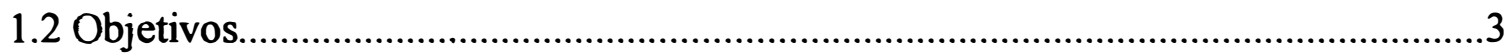

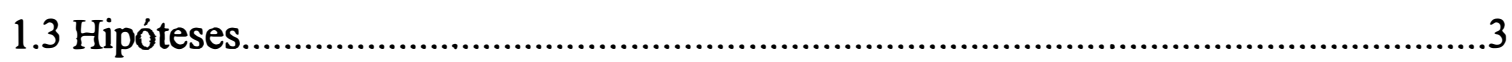

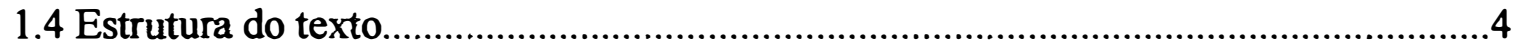

2 PANORAMA MUNDIAL DA SUINOCULTURA.......................................6

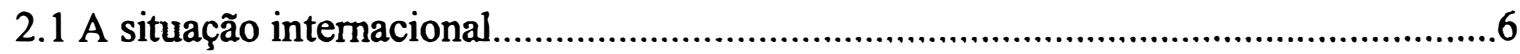

2.2 Inserção brasileira no contexto mundial ........................................................... 16

3 SISTEMA AGROINDUSTRIAL SUINÍCOLA BRASILEIRO ..........................20

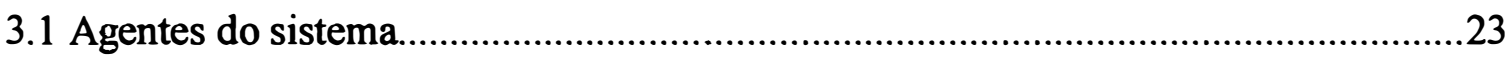

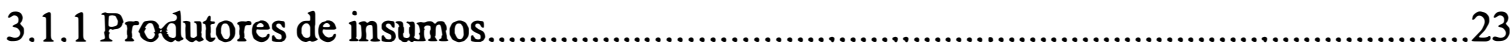

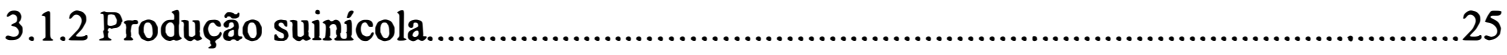

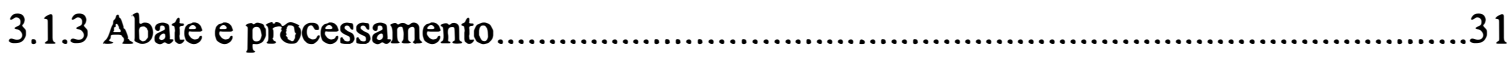

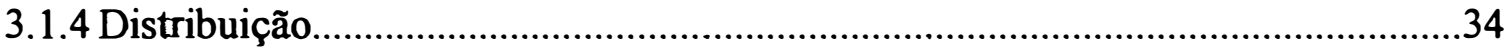

4 REFERENCIAL TEÓRICO

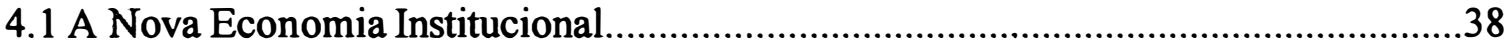

4.1.1 Competitividade na visão da Nova Economia Institucional..............................48

4.2 Margens de comercialização.........................................................................52

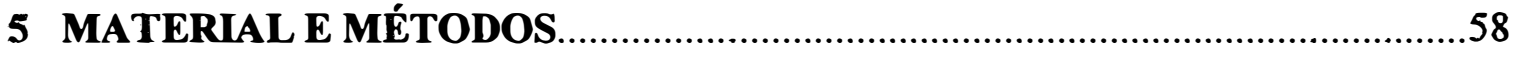

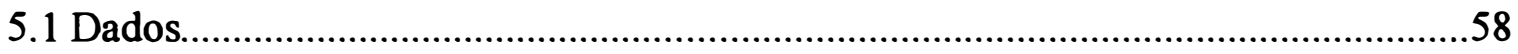

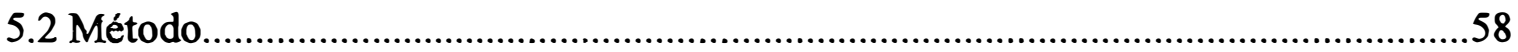

5.2.1 Metodologia de pesquisa para o enfoque da NEI...........................................58 
5.2.2 Metodologia utilizada na determinação das margens de comercialização.............60

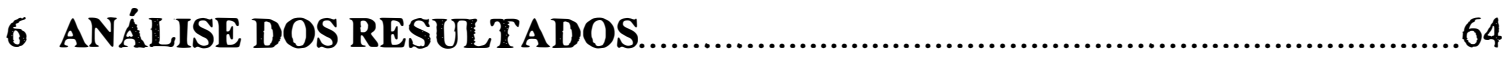

6.1 Referente à hipótese da Nova Economia Institucional......................................64

6.1.1 Aplicação do modelo proposto......................................................................68

6.2 Referente à hipótese de margens de comercialização..............................................78

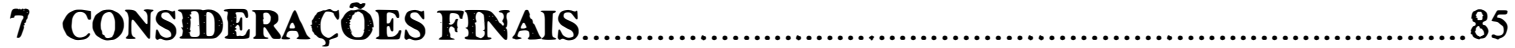

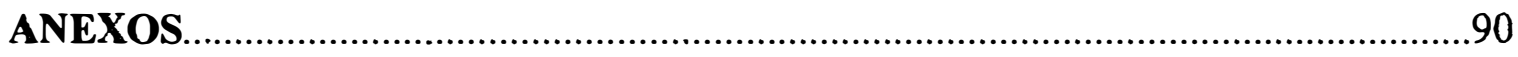

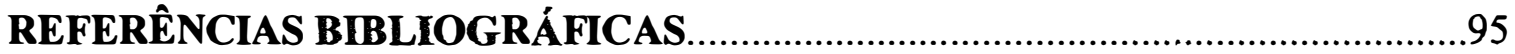

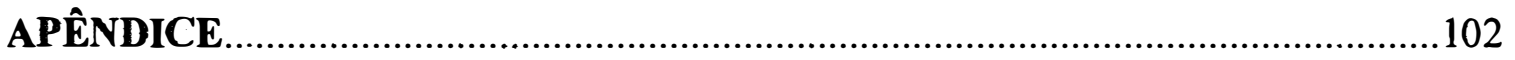




\section{LISTA DE FIGURAS}

Página

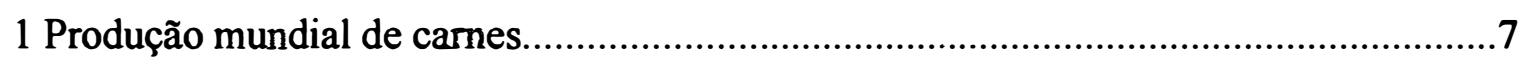

2 Demanda por cereais de acordo com a renda populacional............................................

3 Produção de cames no Brasil..................................................................................17

4 Consumo per capita de cames no mundo em 1996....................................................18

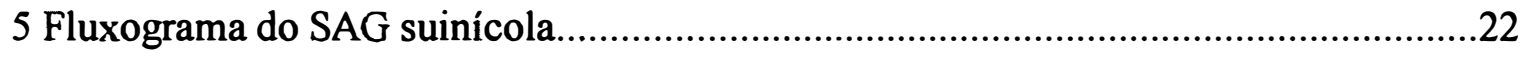

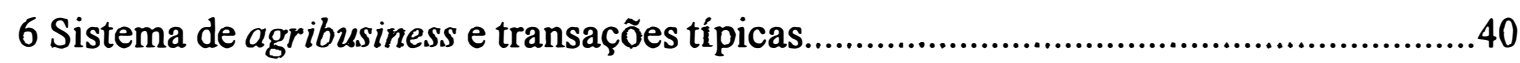

7 Especificidade dos ativos e mecanismos de govemança................................................47

8 A estrutura conceitual de competitividade

9 Margens de comercialização e preços.......................................................................5

10 Estruturas de govemança observadas no Brasil.........................................................74

11 Especificidade dos ativos e estruturas de govemança...................................................77

12 Especificidade dos ativos e estruturas de govemança com a indicação dos ajustes sugeridos.

13 Preços médios em reais dos cortes das carnes no varejo da Cidade de São Paulo.....82 
14 Relação de troca dos cortes das carnes no varejo da Cidade de São Paulo.................82

15 Margens de comercialização do varejo para as carnes em porcentagem......................83

16 Margens totais de comercialização das carnes em porcentagem...................................83 


\section{LISTA DE TABELAS}

Página

1 Participação percentual no custo de produção do suíno no Brasil .25

2 Abatedouros de suínos e suas participações no mercado nacional em 1994.

3 Diferenciados grupos de abatedouros no Brasil .34

4 Média das margens de comercialização em porcentagem das carnes no Brasil entre janeiro de 1989 e julho de 1996 e da carne suína nos EUA entre 1970 e $1995 . . . .80$ 


\title{
COMPETITIVIDADE DO SISTEMA AGROINDUSTRIAL SUINÍCOLA BRASILEIRO
}

\author{
Autor: RICARDO COTTA FERREIRA \\ Orientador: Prof. Dr. PEDRO VALENTIM MARQUES
}

\section{RESUMO}

Apesar da came suína ser a proteína animal mais consumida mundialmente, no Brasil, a história é um pouco diferente. Mesmo apresentando aparentes vantagens comparativas em nível internacional, a produção e o consumo nacional permanecem estagnados há vários anos. A partir desta problemática de visível falta de competitividade, tentou-se identificar os gargalos econômicos no sistema e sugerir mudanças a fim de reverter esta situação.

Identificou-se que é na comercialização que se centralizam os influenciadores negativos do sistema, podendo estes serem subdivididos em relação ao preço-ou não-da carne suína. Para justificar a hipótese referente à questão não-preço, buscou-se, na Nova Economia Institucional, o respaldo teórico de análise das relações contratuais entre produtores e indústrias. Já com referência à questão preço, a teoria de margens de comercialização conseguiu suprir com eficiência os questionamentos.

Chegou-se à conclusão de que alguns ajustes deveriam ser feitos nos arranjos contratuais entre produtores e indústrias a fim de melhorar a coordenação do sistema, minimizando custos de transação e ganhando competitividade. Provou-se que, devido à 
diversificação dos modos de criação e perfil dos produtores nas diversas regiões brasileiras, o ativo suíno apresenta-se mais específico em determinadas localidades do que em outras. Com a carência de abatedouros de suínos no Estado do Mato Grosso, a solução encontrada para aqueles produtores foi integrarem-se verticalmente, unindo-se e fazendo seus próprios frigoríficos. Para os atuais praticantes do livre mercado, concentrados na Região Sudeste, algum tipo de contrato de longo prazo de fornecimento de cevados terminados seria justificável para minimizar as oscilações mercadológicas. Por outro lado, observou-se que o sistema de "quase-integração" praticado no sul do país deveria perder um pouco sua rigidez por ser de elevado custo para as empresas e de pouca autonomia para os produtores.

No que tange à questão relativa aos preços, verificou-se que estes são sempre mais elevados para a came suína se comparada com suas duas concorrentes mais próximas (bovina e de frango). Quando feitos os cálculos das margens de comercialização, observou-se que o problema encontra-se no setor varejista. Mesmo sabendo que a maior parte das margens é determinada nesta fase, verificou-se que comparativamente esta se apresenta em um patamar bastante superior ao das outras cames, assim contribuindo para justificar a referida estagnação de consumo.

Outros problemas no sistema foram identificados e citados no texto, mas acredita-se que, em se tratando de questões econômicas, as duas hipóteses destacadas são as mais relevantes. Espera-se ainda que esta dissertação possa contribuir para uma melhor compreensão destes entraves, além de auxiliar os agentes atuantes no setor a encontrarem altemativas para melhorar a competitividade do sistema agroindustrial suinícola nacional. 


\title{
COMPETITIVENESS IN THE SWINE AGROINDUSTRIAL SYSTEM IN BRAZIL
}

\author{
Author: RICARDO COTTA FERREIRA \\ Adviser: Prof. Dr. PEDRO VALENTIM MARQUES
}

\section{SUMMARY}

Although pork is the most consumed animal protein source around the globe, in Brazil things are different. Even bearing clear comparative advantages at international level; national production and consumption rates have remained stalled for many years. In addressing this problem of lack of competition, we tried to identify the bottlenecks in the system and suggest changes in order to overtum this picture.

The system is being negatively influenced by both the price and the non-price issues related to this type of meat. In the part of New Economic Institution called Transaction Cost Economic we gathered enough theoretical backing from the analysis of contract relationships between producers and the industry to explain the hypothesis regarding the non-price issue. Now, regarding the price issue, the theory of Marketing Margins was fully capable of providing answers to our questions.

We then concluded that the contracts between producers and industry should be trimmed in order to improve the system coordination, thus reducing the transaction cost and gaining competition advantages. It has been proved that due to the wide diversity in breeding modes and producer's profiles in the many brazilian regions, the swine asset 
can be more specific for some areas than in others. Due to the lack of pig slaughterhouses in the State of Mato Grosso, the producers there have gathered themselves vertically integrated. For the current players in the free market, clustered in the southeastern region of the country, some kind of long-term supply contract of finished barley would be accepted in order to minimize the market variances. From the other hand, we have observed that the "almost integration" system used in the south of Brazil may lose its obduracy for accruing high cost to the companies and reducing the autonomy of the producers.

In regards of the price issue, we have ascertained that marketing margins is always higher for pork when compared to the two closest competitors (beef and poultry). When we calculated the marketing margins, we have noticed that the problem lies more in the retail business. Even knowing that the large majority of the margins are set at this stage, we have seen that, comparatively, it is kept in a much higher ground than the others are, thus contributing to explain the aforementioned stagnation in its consumption.

Other problems in the system were diagnosed and mentioned throughout the text. However, we believe that regarding economic issues the two highlighted aforementioned hypothesis are of the utmost importance. We also hope that this paper may contribute somehow to fulfilling its aim in improving the competition capability of the national swine system. 


\section{1- INTRODUÇÃO}

\subsection{Importância e problemática}

Segundo Gomes et al. (1992) a criação de suínos encontra-se presente em 46,5\% dos 5,8 milhões de propriedades rurais existentes no Brasil. Nesta contabilidade, estão consideradas conjuntamente as criações de subsistência, com a utilização predominante do "porco tipo banha", detentoras de baixos índices zootécnicos, e também as criações tecnificadas que adotam as mais modernas técnicas de manejo, nutrição e genética, podendo ser facilmente comparadas com as melhores granjas do mundo.

A suinocultura é bastante representativa no agribusiness brasileiro por ser uma atividade correlacionada com uma variada gama de setores que a complementam. $\mathrm{O}$ principal deles é o complexo grãos, uma vez que provêm deste os insumos básicos à produção suinícola.

Atualmente, com a difusão do consumo de óleos vegetais e da utilização de refrigeradores nas residências para a conservação dos alimentos, o "porco banha" cede cada vez mais espaço para os criados em granjas tecnificadas, ficando seu consumo praticamente restrito à subsistência de famílias rurais de menor poder aquisitivo. Isto porque, há até vinte anos, tanto conservação quanto frituras eram feitas, em grande parte, com a utilização de banha suína. No entanto, o suíno proveniente de granjas modernas têm como função apenas a transformação de ração em carne magra, valorizando as partes nobres como pernil e lombo. 
Mesmo possuindo o quarto maior rebanho mundial de suínos, com aproximadamente 30 milhões de cabeças, o Brasil ocupa apenas a décima quarta posição no ranking produtivo mundial, com 1,5 milhão de toneladas equivalente-carcaça produzido em 1995, de acordo com a Associação Brasileira dos Criadores de SuínosABCS. A principal justificativa para esta visivel baixa produtividade deve-se à grande variabilidade dos sistemas de produção no território nacional, demonstrando ineficiência produtiva e consequente perda de competitividade.

A carne suína é a proteína animal mais consumida mundialmente, mas, no Brasil, a situação é bem diferente. Sua produção e seu consumo em território nacional permanecem praticamente inalteradas há quase dez anos, mesmo possuindo determinantes de aparente vantagem comparativa intemacional, tais como clima favorável, reduzidos preços de instalações, mão-de-obra abundante e baixos custos de produção, devido principalmente aos competitivos preços dos grãos. Então, por que esta estagnação? Quais seriam os pontos de estrangulamento? Poderia estar na ineficiência das relações contratuais entre produtores e indústrias? Estaria nos preços relativos do produto final devido a suas margens elevadas? Restringir-se-ia à má imagem da carne suína na opinião pública nacional? Estaria na incapacidade de abertura de mercados externos mais expressivos? Ou na frágil organização das representações políticas das associações e federações que pouco influenciam o setor?

As afirmações e os questionamentos anteriores levam a crer na falta de competitividade da suinocultura brasileira, resultante de uma coordenação ineficiente de elos da cadeia. Os motivos que prejudicam a coordenação necessitam ser diagnosticados e combatidos o mais rapidamente possivel, podendo trazer consequências favoráveis a todos os agentes envolvidos e, principalmente, ao consumidor final, cujas necessidades poderiam ser supridas com um produto de melhor qualidade e menor preço. Uma maior eficiência no sistema elevaria sua competitividade, proporcionando facilidade na tentativa de uma expansão mais agressiva do mercado externo. Como consequência, 
representaria um desenvolvimento para o setor suinícola nacional, gerando divisas, impostos e empregos que formam os objetivos básicos de toda atividade produtiva. É por estas razões que se optou por estudar a suinocultura através de uma visão sistêmica, analisando sua coordenação como fator de competitividade.

\subsection{Objetivos}

O referido trabalho tem como objetivo central estudar o atual Sistema Agroindustrial (SAG) Suinícola brasileiro, detectando gargalos na comercialização da came suína, e, assim, poder contribuir para o aumento de sua competitividade.

Pretende-se, especificamente:

a) Analisar e justificar as formas alternativas de organização comercial entre produtores e indústrias prevalecentes na suinocultura nacional, além de identificar as que melhor se adequariam às condições locais.

b) Elaborar um estudo de margens de comercialização da carne suína para os últimos oito anos, individualizando-as para os setores de produção, atacado e varejo e as comparando com as carnes concorrentes.

\subsection{Hipóteses}

Existe uma visivel falta de competitividade na suinocutura brasileira. Diante desta hipótese aparentemente óbvia, tentar-se-á testá-la desmembrando-a em duas:

a) Os modos alternativos das relações comerciais entre produtores de suínos e frigoríficos observadas no Brasil não estão se mostrando suficientemente eficientes. 
Estas referem-se tanto ao modelo "quase-integracionista" do sul do país quanto ao sistema "independente" das outras regiões.

b) Quando um setor se apropria de maior margem de comercialização em detrimento de outro, há perda de competitividade sistêmica. Para a carne suína, o setor varejista age desta maneira, fazendo com que o elevado preço final desta em relação às concorrentes (bovina e frango) contribua para inibir seu consumo.

\subsection{Estrutura do texto}

No Capítulo II - Panorama Mundial da Suinocultura - a idéia será apresentar sumariamente o que está acontecendo no mundo em termos de suinocultura para posterior apresentação do Brasil diante deste contexto. O primeiro subitem contém algumas observações sobre como é organizado o setor nos diversos continentes, mostrando o desenvolvimento e as tendências de atuação dos países com significativa participação. $O$ fato de apresentar o potencial brasileiro logo em seguida é proposital, a fim de contrastar as tendências e demonstrar os pontos fracos que impedem um maior crescimento produtivo.

O terceiro capítulo, Sistema Agroindustrial Suinícola Brasileiro, procura descrever cada fase do sistema enfatizando as relações contratuais estabelecidas, além de destacar os tipos de criação e como o setor de produção se inter-relaciona com os demais elos, seja "para trás", com fornecedores de insumos, ou "para frente", com os setores de abate e distribuição.

No Capítulo IV - Referencial Teórico - far-se-á uma revisão bibliográfica sobre o tema proposto. No primeiro subitem, será descrita de forma sucinta a Nova Economia Institucional (NEI), não entrando no mérito histórico, pois vários trabalhos foram recentemente publicados buscando descrever e desenvolver esta teoria. A idéia aqui 
será, meramente, aplicá-la em um setor produtivo carente de estudos relacionados a este tema. O capítulo busca enfatizar, porém, somente as principais variáveis necessárias à aplicação do modelo proposto, isto é, especificidade dos ativos e estruturas de governança.

O segundo subitem refere-se a outra questão também identificada como importante gargalo do setor, as margens de comercialização. Uma revisão bibliográfica será feita buscando subsídios para aplicação deste método à came suína.

No Capítulo V - Material e Métodos - será apresentada a metodologia utilizada para o desenvolvimento e a comprovação das hipóteses sugeridas. Cada uma terá sua base metodológica apresentada separadamente. Será descrito, também, onde foram conseguidos os dados e como foram feitas as entrevistas.

No Capítulo VI são analisados os Resultados obtidos na pesquisa. No primeiro subitem, os resultados referentes à Nova Economia Institucional demonstram que, com pequenos ajustes nos sistemas de comercialização, todo o sistema poderia tornar-se mais eficiente. Já a segunda parte prende-se aos resultados provenientes da análise numérica e gráfica das margens de comercialização. Nesta, detectou-se que as margens de comercialização da carne suína são superiores às das carnes concorrentes, fator este registrado principalmente no mercado varejista.

O último capítulo restringe-se às Considerações Finais, demonstrando que a comercialização do suíno é o grande gargalo da cadeia e comprovando as hipóteses sugeridas inicialmente. Ainda neste capítulo, são sugeridas novas mudanças e idéias de trabalhos a serem desenvolvidos a posteriori. 


\section{PANORAMA DA SUINOCULTURA MUNDIAL}

Este capitulo tem como princípio descrever o que vem acontecendo em termos de suinocultura em alguns dos principais paises atuantes neste setor, sejam eles produtores, exportadores ou importadores. Sua análise é de extrema relevância para a posterior inserção da posição brasileira, demonstrando a possibilidade de, eventualmente, este tornar-se um grande exportador desta proteína, gerando mais emprego, renda e divisas.

\subsection{A situação internacional}

A carne suína vem, há algum tempo, liderando o ranking no consumo mundial de proteína animal. Por apresentar características que facilitam sua transformação, pode ser ofertada sob diversas opcões de consumo, levando à ampliação de sua participação em uma época na qual são marcantes as modificações nos hábitos alimentares. A praticidade é cada vez mais almejada pelos consumidores, juntamente com uma demanda maior por lanches rápidos.

A carne de frango, por também possuir estas peculiaridades, vem aumentando proporcionalmente sua participação mundial, mas ainda encontra-se muito aquém da hegemonia suína, podendo, em um futuro próximo, alcançar a segunda colocação, hoje ocupada pela came bovina (Figura 1). Sua principal vantagem está relacionada ao seu preço relativo, o que vem contribuindo para uma expansão no consumo, principalmente nos países em desenvolvimento. 
A produção mundial de proteína animal, segundo estimativas da FAO citado em WTO (1995) situa-se no patamar de 175 milhões de toneladas equivalente-carcaça (t.e.c.). Deste total produzido em 1994, 76,5 milhões ou 43,7\% são de origem suína. Nos últimos seis anos, ocorreu um crescimento de aproximadamente $13 \%$ na produção desta carne, enquanto a de aves apresentou um acréscimo de $28 \%$ e a bovina demonstrou ligeiro declínio. O maior crescimento da produção suinícola foi observado nos países de economia emergente, particularmente a China, e na América do Norte. Uma melhora qualitativa genética e nutricional, juntamente com um manejo mais adequado, vem colaborando para o incremento destas cifras, resultado de uma maior taxa de desfrute. $\mathrm{Na}$ Europa, presencia-se uma estagnação da produção, enquanto, nos países da Europa Oriental, Rússia e Japão, a redução é marcante.

Mesmo sendo a China a grande responsável pela maior parte da produção mundial de carne suína, não se pode afirmar que seu consumo restringe-se ao continente asiático. Países europeus e norte-americanos também são significativos produtores e consumidores. Não se observa, porém, nenhuma existência de concentração de produção ou consumo mundial.

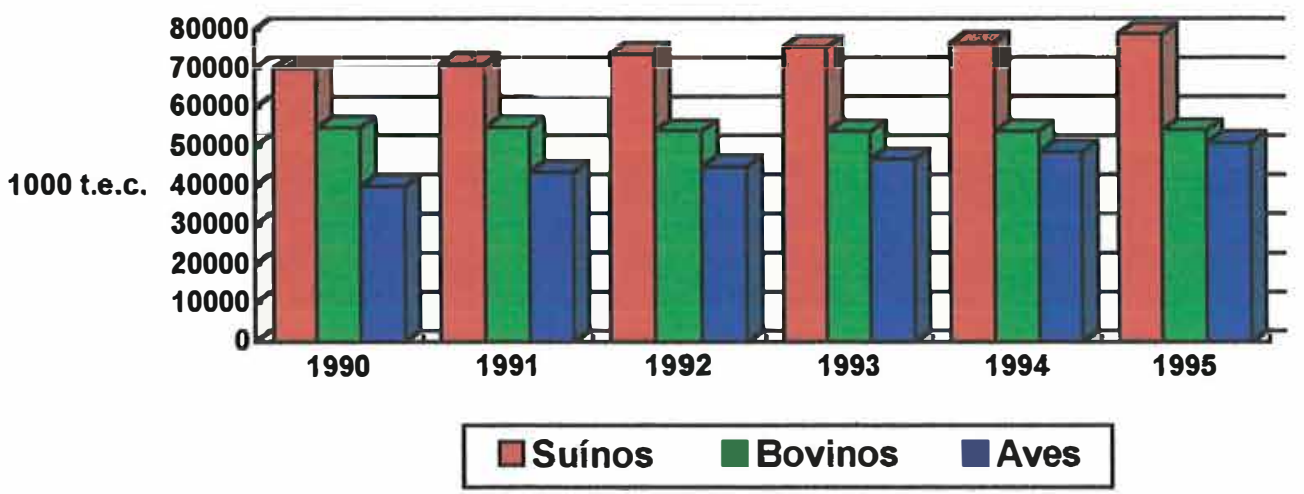

Fonte: FAO

Nota: Os dados referentes aos anos de 1994 e 1995 são estimados

Figura 1 - Produção mundial de carnes 
Apesar do elevado volume de produção, o comércio internacional de carne suína é bastante reduzido, não ultrapassando o 1,8 milhão de toneladas em 1994 estimado pelo WTO (1995), representando $2,35 \%$ do total produzido mundialmente e um volume monetário de mais de US\$ 10 bilhões anuais (Rabobank, 1993). Deste total, quase a metade é comercializada dentro da Comunidade Européia. O baixo volume é justificado pelo alto grau de protecionismo deste mercado, mas movimentos para torná-lo mais livre e concorrencial são cada vez maiores. As exportações são condicionadas à imposição de barreiras não-tarifárias, relacionadas principalmente às questões sanitárias.

Exportações subsidiadas, frequentes nesta atividade, também estão sofrendo pressões de redução. Como resultado da Rodada Uruguai do GATT, a Comunidade Européia será obrigada a reduzir as exportações que estiverem neste contexto de $491 \mathrm{mil}$ toneladas em 1995 para 402 mil toneladas até o ano 2000 (WTO, 1995). Esta é uma redução bastante tímida, mas, em um setor até então considerado intocável para os europeus é entendida desde já como um grande avanço.

\section{$\underline{\text { Ásia }}$}

Mudanças na suinocultura mundial são esperadas para um futuro próximo. $O$ "boom" de crescimento econômico vivido pelos países asiáticos, principalmente a China, elevando o poder aquisitivo da população, tende a transformar estes países de exportadores em eventuais importadores de alimentos.

A crise financeira em alguns destes países, no segundo semestre de 1997, não deve influenciar muito as questões referentes à produção suína, pois esta concentra-se na China, país não afetado diretamente.

Quedas nas exportações de produtos agrícolas nos países asiáticos já podem ser observadas e, devido à restrição de área cultivável e à baixa produtividade provocada principalmente pela estrutura fundiária formada por minifúndios que dificultam a 
economia de escala, poderão levar, brevemente, a uma insuficiência de oferta de matéria-prima nacional para suprir a demanda na fabricação de rações.

Cereais são a maior fonte de calorias para as classes populacionais de menor renda. Nas classes de renda mais elevada, estes também têm sua importância. A única diferença é que são consumidos indiretamente sob a forma de proteína animal. A mudança do consumo de cereais de direto para indireto, à medida que a renda evolui, representa uma mudança na composição da cesta de consumo, do grão para a came. Como a conversão alimentar do animal varia entre aproximadamente $2: 1^{1}$ para aves, 3:1 para suínos e até 7:1 no caso dos bovinos, a demanda por grãos de uma população de renda ascendente tende a crescer geometricamente. Yotopoulos (1985) explica estas mudanças através da "plotagem" de um gráfico de demanda por cereais sob forma direta $(f \circ o d)$, indireta $(f e e d)$ e total em relação à renda (Figura 2). Esta mudança de estágios é denominada efeito-graduação e tem em seu ponto mais avançado a utilização sob forma de combustível renovável, completando assim a evolução “food-feed-fuel".

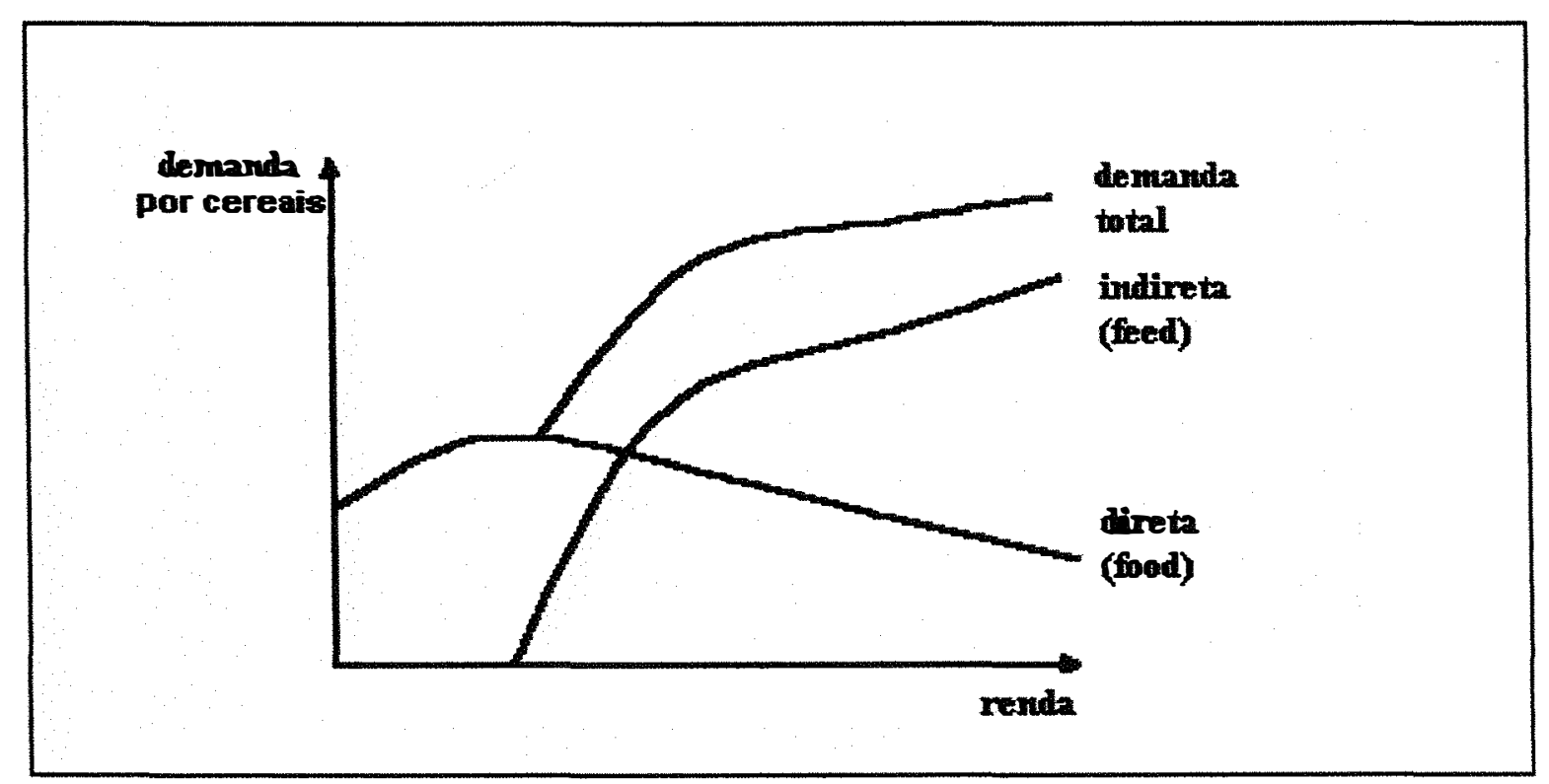

Fonte: Yotopoulus (1985, p. 467).

Figura 2 - Demanda por cereais de acordo com a renda populacional 
Pode-se então observar que, à medida que a renda se eleva, a demanda por cereais sob a forma indireta, apresentando alta elasticidade-renda ${ }^{2}$, cresce rapidamente. Já a elasticidade-renda da demanda na forma direta declina com o aumento da renda.

A carne suína, por ser a mais difundida nos países asiáticos ${ }^{3}$, tende a sofrer uma impulsão de produção à medida que o desenvolvimento econômico se efetive. Diante deste quadro, a China deve continuar sendo, de longe, o maior produtor mundial de carne suína, representando atualmente quase $40 \%$ da produção mundial. Em 1994, segundo WTO (1995), esta produção alcançou a marca dos 31,2 milhões de toneladas, apresentando um crescimento de $8 \%$ em relação ao ano anterior. Existem dois sistemas produtivos básicos nesse país. Os mais de 12 milhões de pequenos produtores que, juntos, contribuem com $84 \%$ da produção total e o limitado número de grandes granjas estatais que produzem $11 \%$ segundo o relatório do Rabobank (1993, p.31).

É importante também destacar o Japão, pois, mesmo não detendo condições naturais favoráveis para a criação de suínos, é o sexto maior produtor mundial. Com a elevação dos custos de produção, o auto-abastecimento deste mercado reduziu-se de $77 \%$ em 1989 para 69\% em 1993, ainda segundo WTO (1995). Esta característica vem levando o Japão a tornar-se um promissor importador do ocidente, pois os atuais supridores desse mercado, os vizinhos asiáticos, estão tendo sua demanda interna aumentada e, consequentemente, reduzindo os excedentes exportáveis.

Supridor de $40 \%$ das importações japonesas de carne suína, Taiwan vem passando, desde a segunda metade de 1996, por uma séria crise no setor devido a problemas sanitários que vêm obrigando a execução de boa parte do rebanho encontrado sob suspeita. Como consequência, o mercado externo reduziu-se drasticamente.

\footnotetext{
${ }^{1}$ Taxa de conversão alimentar de 2:1 significa que são necessários 2 quilogramas de ração para produzir 1 quilograma de came.

${ }^{2}$ Os conceitos de elasticidade-renda podem ser vistos detalhadamente na maioria dos livros de microeconomia.
} 
Hong Kong, apesar de não constar na lista de significativos produtores, destacase como grande importador, não somente para seu consumo interno, mas também servindo como triangulador da mercadoria a outros países asiáticos. Com a recente reincorporação desse pequeno país à República Popular da China, abre-se uma possibilidade de facilidade de colocação do produto no imenso mercado chinês.

\section{Europa}

A atividade suinícola européia é de extrema relevância. Com uma produção de 14,38 milhões de toneladas em 1992 (ITP, 1993) e utilizadora de alta tecnologia, detém um importante valor econômico e social (Anexo 1, Tabela de Produção Européia). Em países como a Dinamarca, acredita-se que esta cadeia chegue a representar uma marca próxima a $20 \%$ do PIB nacional ${ }^{4}$. Este possui um excedente exportável de mais de três vezes o seu consumo nacional e praticamente toda a produção é comercializada através de contratos com as cooperativas ${ }^{5}$. Suas exportações são principalmente para os mercados britânico e alemão. $O$ preço é único e estipulado nacionalmente pela organização dos abatedouros cooperados (Danske Slagterier). Por esta razão, seu sistema é organizado e simplificado em comparação a outros países.

Dos principais países produtores, o líder é a Alemanha, com 9,53 mil toneladas equivalente-carcaça. Mas, desde a reunificação, vem baixando seu efetivo, sobretudo na região da ex-RDA, onde a atual produção representa apenas $25 \%$ do que existia antes da reunificação. Problemas de ordem sanitária como a peste suína, que reapareceu há dois anos, também vêm colaborando com esta redução. Nesse país, a comercialização é feita diretamente com seus mais de 400 frigoríficos dos quais $29 \%$ pertencem a cooperativas.

\footnotetext{
${ }^{3}$ Segundo o GATT (1994), em 1992, 78\% do total de carne consumida na China foram de carne suina.

${ }^{4}$ Porc Magazine no. 268 de junho de 1994, p.9.

${ }^{5}$ Existem cinco grandes cooperativas na Dinarnarca e a maior delas, Danish Crown, abate quase a metade da produção nacional, sendo a maior empresa abatedoura em toda a Europa.
} 
A bolsa de mercadorias efetiva aproximadamente 3\% dos negócios de acordo com o relatório do Rabobank (1993, p.39).

A maior parte da produção é consumida intra-CE mesmo, tendo um excedente de apenas 3,9\% em 1992 (ITP, 1993). A maior parte dos estabelecimentos produtivos situase no litoral, próximo a alguma infra-estrutura portuária de grande porte. A explicação estaria relacionada à obtenção de menores custos de produção, devido à facilidade de suprimento de matérias-primas para a elaboração de ração, normalmente importadas. Esta concentração regional gera grandes problemas ambientais. Controles cada vez mais rigorosos de poluição dos mananciais de água e saturação do solo por dejetos estão exigindo investimentos cada vez mais elevados, com a finalidade de tratá-los, o que, muitas vezes, inviabiliza economicamente novos projetos.

Em praticamente todo o continente europeu, prevalecem as granjas de pequeno porte, mas, recentemente, observa-se uma tendência generalizada de redução do número de granjas em detrimento do aumento de animais nestas, isto é, maior concentração da produção. Com a redução das margens, a escala produtiva tem enorme importância na baixa dos custos.

O consumo europeu é bastante elevado, apresentando uma média de aproximadamente 40 quilos per capita anuais, sendo que, em alguns paises, este número ultrapassa os 60 quilos por habitante por ano (ITP, 1993). O clima propício e o alto poder aquisitivo, aliados aos tradicionais hábitos culinários, contribuem para esta elevada cifra.

A grande maioria dos produtores é filiada a algum tipo de associação ou cooperativa, que a auxilia na comercialização das matérias-primas e do produto final. $\mathrm{Na}$ França, por exemplo, 88\% dos suinocultores são cooperados (ITP, 1993). Algumas cooperativas possuem suas próprias indústrias abatedouras e processadoras, caso da 
Cana e Olymel; outras preferem deter alguma participação acionária a fim de garantir a colocação de sua produção, como a ARCO. Empresas que praticam algum tipo de integração com produtores existem, mas não são significativas no caso dos suínos. Em praticamente todos os países europeus, a força política dos sindicatos e das federações de produtores é muito ativa, o que leva a uma proteção constante dos produtores locais, defendendo seus interesses e facilitando a comercialização.

A Europa constitui um imenso mercado, muito remunerador, mas inacessível ao exterior graças a um protecionismo atuante que age sob dois mecanismos básicos da Política Agrícola Comum (PAC): o preço de eclusa e as restituições às exportações. $\mathrm{O}$ preço de eclusa consiste em um valor mínimo, impedindo que o preço do quilo de carcaça se situe abaixo dele. A justificativa para sua aplicação é a política antidumping baseada nos custos de produção mundial. A este valor é acrescido outro montante destinado à compensação da diferença de preços dos cereais dentro e fora da Comunidade Européia. Assim, o preço mínimo que um quilo de carcaça poderia atingir seria próximo de US\$2.30, o que seria totalmente inviável se comparado aos preços locais. Já a restituição tem um papel inverso. Nada mais é que um subsídio às exportações quando a conjuntura apresenta-se favorável.

Com o acordo do GATT, toda esta sistemática deve ser substituída por uma tarifa aduaneira fixa chamada de equivalente tarifário. O fim da Rodada Uruguai implicou que tanto os subsídios dados à equiparação do preço dos cereais quanto as restituições às exportações deverão ser reduzidos em $36 \%$ em orçamento e $21 \%$ em volume até 1999 . Embora pequenas, estas medidas já indicam certa força contrária às subvenções agrícolas européias.

Pressões mundiais, no sentido de forçar a queda das exportações subsidiadas e de reduzir as barreiras tarifárias e não-tarifárias, podem influenciar negativamente a produção desses países, uma vez que não somente a suinocultura, mas praticamente toda 
a agricultura européia são dependentes destes mecanismos protecionistas. Por outro lado, externalidades como a doença da "vaca louca" ou EEB (Encefalopatia Espongiforme Bovina) contribuem para um aumento no consumo da came suína em detrimento da bovina, e problemas como a peste suína clássica incentivam a produção nos países não afetados, devido à alta dos preços.

\section{Europa Oriental e Rússia}

O tradicional hábito de alimentar-se de came suína levou a uma importante produção nos países da Europa do Leste, mas, com o declínio do regime socialista, a economia dos países que se submetiam a este sistema entrou em colapso. Para o setor suinícola, não poderia ser diferente. Enquanto a produção mundial apresenta-se em ascensão, uma redução nesses países é marcante.

Como significante produtor e exportador para a CE nos anos 80, a Polônia começa a apresentar pequeno sinal de recuperação após o péssimo ano de 1993, quando teve seu rebanho reduzido em $17 \%$ segundo o WTO (1995). No mesmo sentido, a Hungria teve seu plantel reduzido a 5,3 milhões de cabeças, diminuindo-o em cerca de 2,5 milhões entre 1990 e 1992 segundo Rabobank (1993, p. 32), mas ainda continua auto-suficiente, devido à redução também no consumo. A Rússia, por sua vez, vem-se mostrando incapaz de reorganizar-se na economia de mercado até então, e a produção de suínos reflete esta situação. Embora a produção privada, que representa um terço do total, tenha aumentado nos últimos quatro anos, em detrimento das grandes fazendas "kolkhoz" e "sovkhoz", esta elevação não foi suficiente para reverter o resultado geral. Somente entre 1992 e 1991, segundo WTO (1995), a variação da produção foi negativa em $10 \%$, passando de 3,19 para 2,86 milhões de toneladas, levando o país a tomar-se um grande importador. 


\section{América do Norte}

Atraída por um elevado consumo interno e reduzidos custos de produção devido a abundância e baixos preços dos cereais, a produção norte-americana de suínos tem-se desenvolvido bastante.

O Canadá, com uma produção de 1,2 milhão de toneladas, é um dos principais paises atuantes no desenvolvimento de genética avançada, atividade que tem colaboração conjunta da iniciativa privada e do governo através das federações. Possui excedente exportável de aproximadamente $30 \%$, destinado principalmente aos Estados Unidos. Por este motivo, o preço é baseado no mercado intemacional. A comercialização é feita também pela federação que possui este monopólio. Apenas $20 \%$ da produção são transacionados via mercado livre. Existem algumas integrações verticais, principalmente de fábricas de rações em busca de ampliação de mercado, que partem para a área de produção de carnes.

Os Estados Unidos, por sua vez, já é o segundo maior produtor mundial e, de acordo com a OCDE, há expectativa de crescimento para os próximos anos. Esta tendência pode retirar os Estados Unidos do ranking de maior importador mundial, transformando-o em um potencial exportador. Nesse país, existe uma clara opção por estabelecimentos produtivos de grandes porte, com mais de 500 matrizes, buscando economias de escala e maior competitividade internacional. Estas granjas, $4 \%$ do total, produzem mais de 40\% de toda came suína dos Estados Unidos (Rabobank, 1993, p.43). Existem também as megagranjas, com mais de 5.000 matrizes, em que prevalece a integração vertical. Consequentemente, os tradicionais sistemas de criações familiares cedem espaço com extrema rapidez.

Em 1994, foi criado um fundo financeiro, administrado pelo National Pork Producers Council - NPPC, a fim de desenvolver uma campanha de marketing, intitulada "A outra came branca", demonstrando ser esta uma saudável alternativa à 
carne bovina e à de frango. Seu sucesso vem fazendo com que o consumo por habitante se amplie, ultrapassando os 30 quilos anuais.

\section{América Latina}

No México, a produção e o consumo estimados pelo GATT em 1993 foram de 870 mil toneladas, cifra esta aproximadamente 600 mil toneladas inferior à do principio dos anos 80. A explicação está relacionada ao fator preço, que vem levando a população a optar pela carne de aves por ser mais barata. A concorrência direta com os parceiros do NAFTA também é um empecilho, uma vez que os outros paises integrantes deste bloco possuem seu sistema mais bem estruturado.

Os parceiros do Brasil no Mercosul não apresentam produção significativa. Os três países em conjunto não produzem mais que 300 mil toneladas anuais. A concorrência no consumo, neste caso, não é com o frango, como no Brasil, e sim com a came bovina, tradicionalmente barata e de boa qualidade.

A Argentina vem se destacando como eminente importador brasileiro de carne suína, podendo vir a aumentar o volume de compras a cada ano. No restante da América Latina, ainda predomina a criação extensiva. É diante deste cenário mundial que o Brasil surge como um país de excepcional potencial produtivo.

\subsection{Inserçāo brasileira no contexto mundial}

A produção de cames no Brasil vem passando por um processo de crescimento desde o início da década de 80, puxada principalmente pela avicultura. Segundo o Centro de Informações da Gazeta Mercantil, o aumento acumulado de 1986 a 1995 chegou a 49,1\% e, deste total, 10,4\% foram conseguidos só em 1995. A elevação do poder aquisitivo, proveniente do controle inflacionário pós-Plano Real pode ser observada como uma guinada no consumo de cames nos anos pós-1994, como mostra a 
Figura 3. A elevação dos preços trouxe consigo um incentivo ao aumento produtivo da atividade. O setor avícola, porém, obteve um aumento superior aos outros devido a um conjunto de fatores que vão desde um bom marketing interno até a busca alternativa do mercado externo. Mas o fator preço é, sem dúvida, o maior responsável por esta ascensão. É dada como certa a primeira colocação desta carne em um futuro próximo, ultrapassando a bovina. Uma perda de fôlego no ritmo de crescimento já pode ser observada após 1995, mas está sendo suprida pelo aumento das exportações.

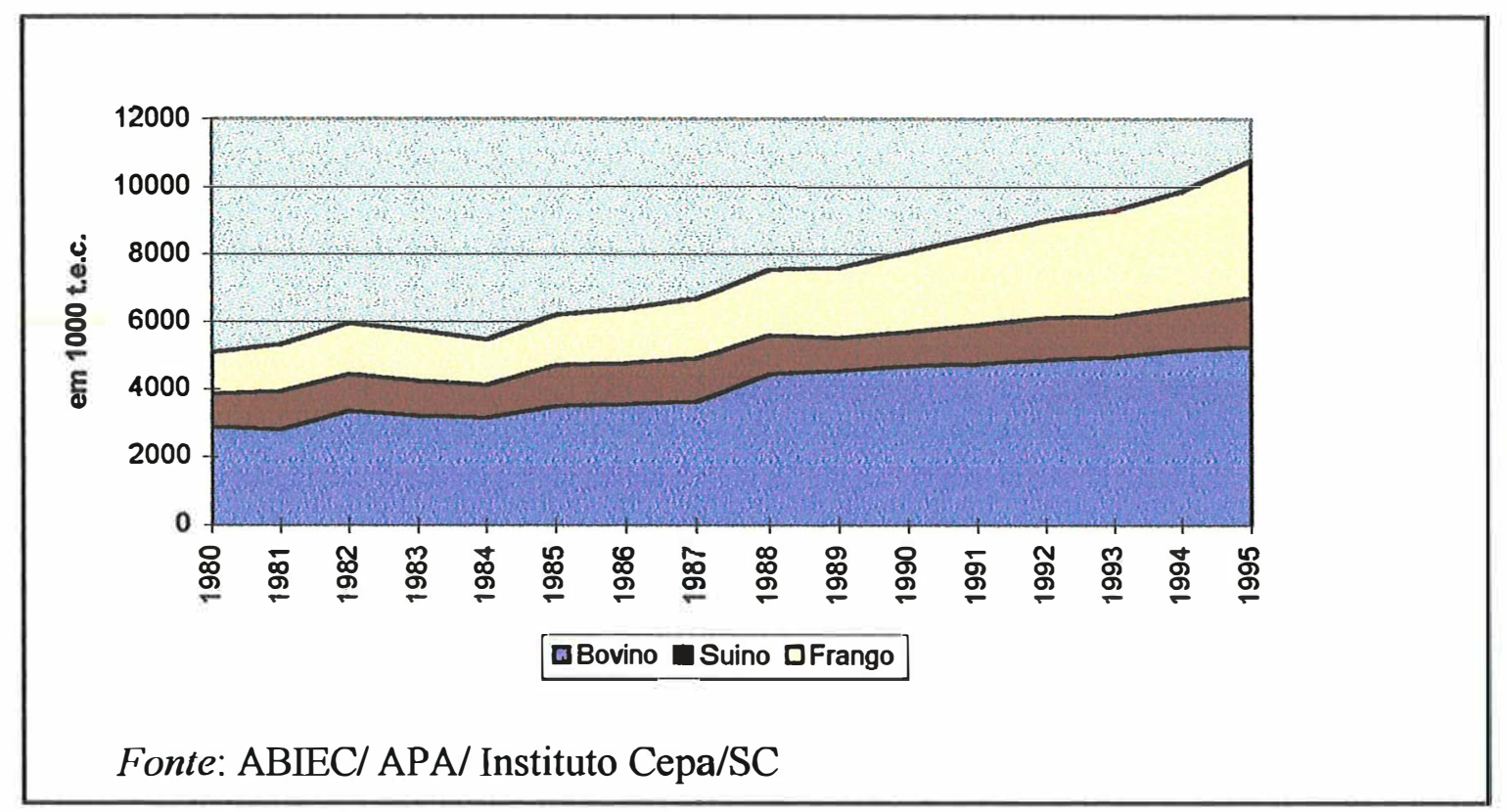

Figura 3 - Produção de carnes no Brasil

Já a carne suína participou com uma produção de 1,4 milhão de toneladas equivalente-carcaça em 1995, mantendo-se estável em quase toda a década anterior. Após a euforia causada pela estabilidade inflacionária de 1994, o setor mostrou pequeno sinal de aquecimento, passando por bons momentos até 1996, quando a produção teve um aumento relativamente superior à demanda. Este foi o fator causador de uma crise momentânea, envolvendo todos os agentes do setor, aprofundada pelas repentinas altas nos preços dos grãos tanto no mercado interno quanto no internacional. 
Apesar de ser considerado um país em desenvolvimento, o consumo de carnes no Brasil situa-se nos patamares das nações mais ricas, chegando próximo da cifra de 70 quilos por habitante por ano, como demonstrado na Figura 4. A carne suína não representa mais que 10 quilogramas anuais desse consumo, enquanto as outras duas carnes principais dividem o restante em proporções semelhantes. Como a participação relativa da carne suína perante suas concorrentes situa-se em níveis bastante inferiores aos de outros países, acredita-se poder haver espaço para expansão, seja ganhando participação internamente, seja abrindo novos mercados externos.

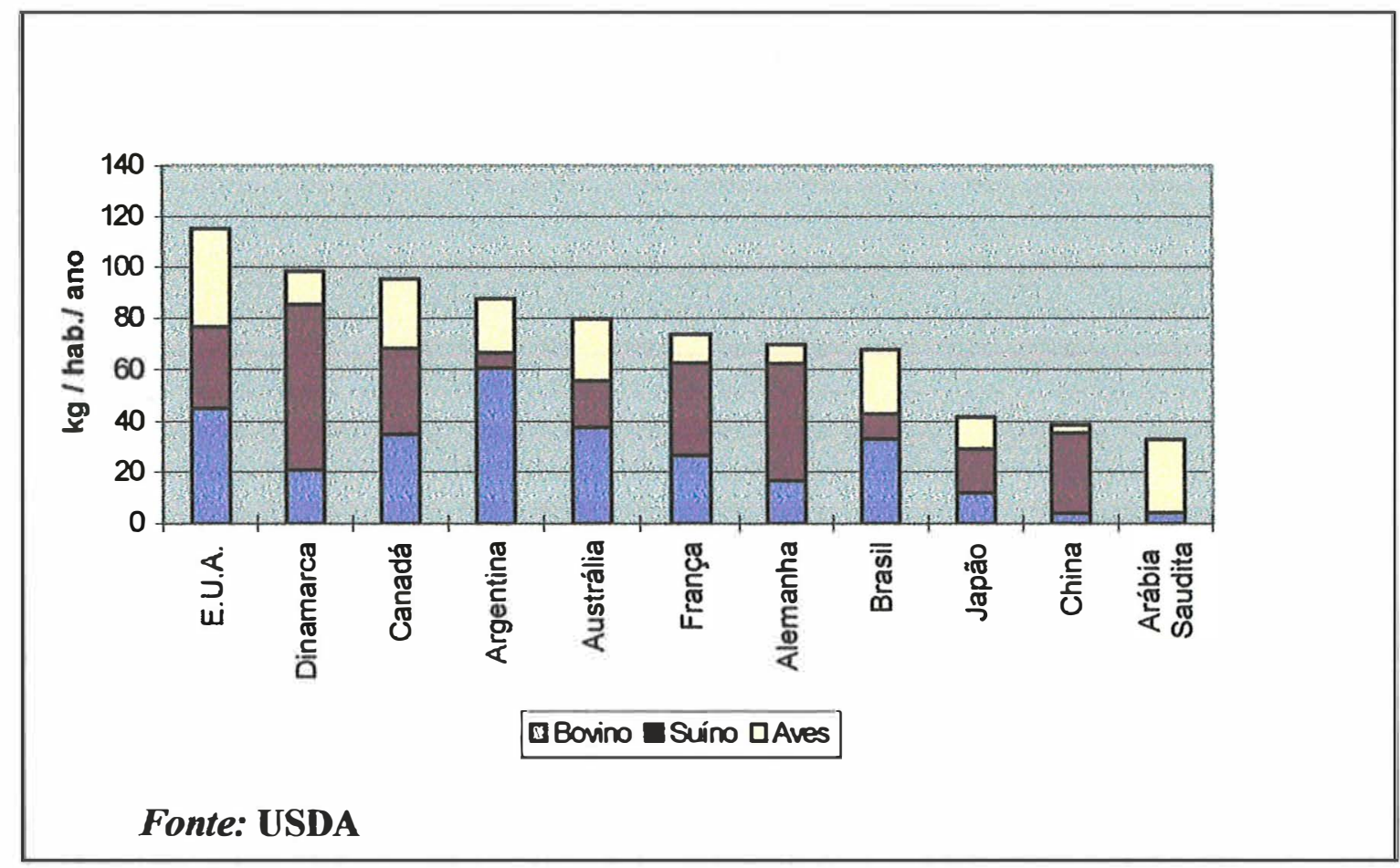

Figura 4 - Consurno per capita de carnes no mundo em 1996

Em sua história, o Brasil nunca chegou a ser grande exportador de carne suína. Em meados dos anos 70, com o dito surto de peste suína, o restrito mercado externo fechou totalmente suas portas ao produto nacional. Mais de una década se passou até se decidir fazer um programa a fim de controlar esta doença, o Programa Nacional de Controle e Erradicação da Peste Suína Clássica. Foram criadas três áreas regionais. Na terceira, seria feita a vacinação, mas somente na área II esta seria obrigatória e administrada. Após 180 dias sem nenhum foco identificado, regiões da área II poderiam 
requerer seu ingresso na última fase ou área I, na qual não seria mais permitida a vacinação, provando, assim, a erradicação da doença. Para melhor controle, o trânsito de animais vivos para essa delimitação, provenientes de outras áreas, seria proibido, evitando possiveis contaminações. Foi criado um fundo monetário de reserva para ser usado no caso de eventual surgimento de algum foco. Se isto ocorrer, os animais serão totalmente eliminados e o produtor será indenizado.

Santa Catarina e Rio Grande do Sul, que já eram estados considerados área livre de peste suína clássica, passaram também a deter este status para a febre aftosa. Estas duas doenças formavam o grande pretexto prejudicial às exportações brasileiras, através da imposição de barreiras não-tarifárias pelos importadores. Com o recém obtido aval da $\mathrm{OIE}^{6}$, comprovando a ausência destas moléstias, mercados até então inteiramente fechados ao produto nacional, como o europeu e o japonês, poderão rever suas posições.

A partir da segunda metade dos anos 80 , porém, tímidas exportações começaram a efetivar-se. Segundo o Instituto Cepa de Santa Catarina, em 1986, o Brasil vendeu ao exterior 8 mil toneladas equivalente-carcaça de suínos. Este valor foi subindo paulatinamente até atingir o volume recorde de aproximadamente $65 \mathrm{mil} \mathrm{em} \mathrm{1996,} \mathrm{e}$ com estimativas de crescimento de pelo menos 20\% em 1997 de acordo com a Associação Brasileira de Exportadores de Came Suína-ABECS, podendo gerar assim uma receita cambial de aproximadamente US\$180 milhões. Apesar deste significativo crescimento das exportações nos últimos anos, estas não representam mais de $5 \%$ da produção nacional. Atualmente, têm como destino final basicamente dois países: Argentina, representando $48 \%$ e, Hong Kong, com $41 \%$.

Podendo oferecer um produto de alta qualidade a reduzido custo, estes números referentes às exportações são irrisórios em vista do potencial produtivo nacional.

\footnotetext{
${ }^{6}$ OIE - Organiząão Internacional de Epizootias, órgão intemacional, sediado na França, que fomece certificados de comprovação de doenças animais.
} 


\section{SISTEMA AGROINDUSTRIAL SUINICCOLA BRASILEIRO}

Este capitulo inicia-se com uma descrição conceitual do que vem a ser um sistema agroindustrial, passando posteriormente para o caso específico do sistema suinícola brasileiro. Para efeito organizacional, optou-se por analisar cada agente do sistema em uma subseção separada, mesmo lembrando que a idéia central é avaliar a competitividade de maneira sistêmica, tendo a coordenação desses agentes como seu principal indicador.

Adota-se aqui o conceito de sistema agroindustrial, utilizado por Goldberg (1968) como CSA (Commodity System Approach), significando uma análise por produto englobando todo seu fluxo, da pesquisa ao consumidor final.

Uma associação de diversos sistemas agroindustriais é o que comumente se denomina agribusiness, cuja metodologia se pretende utilizar neste trabalho.

O CSA dá importância especial ao crescente poder do consumidor como elemento coordenador do sistema de produção e distribuição de alimentos. É esta coordenação um dos elementos fundamentais na determinação da competitividade. Entre as firmas que compõem um determinado sistema agroindustrial, há um interrelacionamento visando garantir seu processo de acumulação. Estas existem sob a forma de relações contratuais que podem ser executadas através do mercado, de contratos ou via integração (Farina \& Zylbersztajn, 1994).

Para que haja maior satisfação do consumidor, é necessáriar uma interação entre os elos da cadeia produtiva, pois somente assim poderá haver comunicação e 
atendimento das necessidades. Deste modo, os distribuidores que estão em contato direto com o consumidor poderão passar e exigir das indústrias processadoras o perfil de produto desejado. As indústrias, por sua vez, tentarão transmitir para seus fornecedores, produtores rurais neste caso, o tipo de matéria-prima que melhor lhes convém para a elaboração do referido produto. Por último, os produtores rurais poderão demandar, de seus supridores de insumos, qualidade e especificidade.

Com preocupações cada vez maiores sobre questões relacionadas à saúde, mudanças nos hábitos alimentares foram marcantes nas últimas duas décadas em todo $\mathrm{o}$ mundo. No complexo carnes, especificamente no sistema suinícola, estas representaram uma grande transformação mundial. Os consumidores passaram a exigir cortes de melhor aparência (textura e coloração), mais higiênicos e, principalmente, mais magros. Os estabelecimentos varejistas voltaram-se para os abatedouros, passando a exigir uma carcaça que pudesse oferecer esses tipos específicos de cortes. Como não era fácil adquirir animais com estas características no mercado, os produtores tiveram de modernizar-se. Inicialmente modificaram o manejo, construindo instalações fechadas em que os animais permanecem totalmente confinados; depois, tiveram de buscar melhorias nas áreas de genética e nutrição. Com todos estes elementos atuando complementarmente, os produtores, então chamados de suinocultores tecnificados, passaram a atender as necessidades exigidas inicialmente pelos consumidores. Devido à assimetria de informações, os produtores que não se adaptassem a essas mudanças exigidas pelos consumidores acabariam saindo do mercado. Esta é a comprovação do ponto central da dissertação em que se adota a coordenação da cadeia como fator de competitividade.

Para o caso especifico da suinocultura, pode-se dividir o sistema em quatro grandes fases, vistos na Figura 5: insumos, produção propriamente dita, abate e distribuição. 


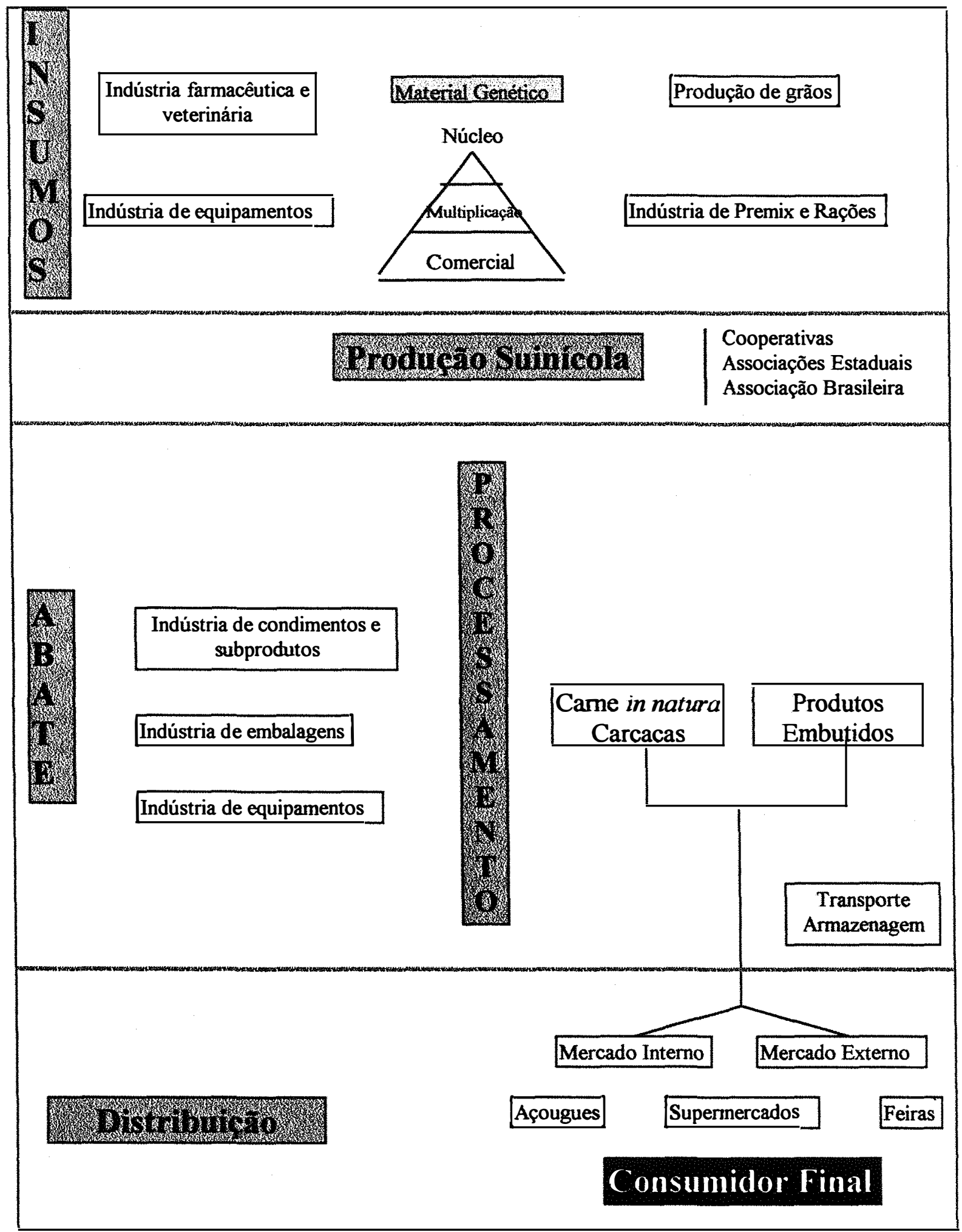

Fonte : Elaboração do autor

Figura 5 - Fluxograma do SAG Suinícola 


\subsection{Agentes do sistema}

\subsubsection{Produtores de insumos}

$\mathrm{Na}$ fase referente a insumos, encontra-se toda gama de indústrias relacionadas à produção de medicamentos, material genético, complexo mineral e vitamínico contido no premix ou na ração, além das fábricas de equipamentos específicos e, obviamente, toda a parte referente à constituição das matérias-primas essenciais para a produção suina, os grãos.

A relação produtor-indústria na comercialização de insumos dá-se basicamente via mercado para medicamentos e materiais de construção e manutenção.

$\mathrm{Na}$ parte relativa à genética pode existir alguma relação contratual. Sua organização processa-se através de uma esquematização piramidal em que, no seu pico, situam-se as granjas-núcleo, normalmente controladas por joint ventures entre grupos nacionais e estrangeiros. Nelas são criados os animais de linhas puras, chamados de bisavós. Existe, neste setor, um constante trabalho de melhoramento, buscando atender às reivindicações dos elos posteriores da cadeia, sejam estas relativas à quantidade de gordura ou espessura de toucinho ou ainda relacionadas à porcentagem de came nobre na carcaça. Após anos de hegemonia de uma única empresa nessa atividade, um grande número de outras companhias instalou-se recentemente no Brasil, buscando conseguir parte desse mercado.

Os filhos selecionados dessas granjas são transferidos para os multiplicadores. Estes são produtores tecnificados responsáveis por produzir as F1, fềmeas ideais para as granjas comerciais devido ao melhor vigor híbrido. Entre as empresas-núcleo e as multiplicadoras, existe um contrato de parceria que normalmente garante à núcleo o 
poder de administrar as vendas de F1 a terceiros, retribuindo ao multiplicador um percentual ou prêmio por matriz selecionada para reprodução.

Por fim encontram-se as granjas comerciais que formam a base da pirâmide. Sua finalidade é apenas produzir cevados para abate. Para produzir 100.000 cevados terminados anuais, são necessárias 4.000 matrizes comerciais F1. Há a necessidade de aproximadamente 220 matrizes avós em multiplicação e 70 bisavós na núcleo.

As fábricas de complexo vitamínico e mineral ou premix normalmente procuram associar-se a alguma empresa de genética ou vice-versa, visando uma maior garantia de mercado. Fábricas de rações prontas vêm reduzindo bastante suas vendas para a suinocultura, pois praticamente todas as médias e grandes granjas preferem fazer sua ração na própria fazenda, seja por questão econômica, seja para poder controlar melhor a qualidade das matérias-primas utilizadas. Algumas destas fábricas, a fim de manter certo volume de venda, integram-se verticalmente na produção animal, mas em números ainda não muito significativos. Granjas de menor porte optam normalmente por comprar ração pronta ou concentrado (núcleo), adicionando somente o milho na própria fazenda.

A maior influência "para trás" da produção suína ocorre mesmo com relação ao complexo grãos. Este é responsável por aproximadamente $55 \%$ dos custos totais de produção, incluídos no percentual de $64,1 \%$ do item ração da Tabela 1 , detalhada no Anexo B. Mesmo sendo este o setor de maior influência na produção de suínos, praticamente inexiste qualquer tipo de parceria entre os produtores de cada atividade, a não ser que alguns suinocultores sejam também produtores de grãos ou o contrário. Esta integração vertical vem aumentando principalmente por parte dos produtores de cereais em busca de maior agregação de valor ao seu produto, transformando-o em carne. 
Tabela 1: Participação percentual no custo de produção do suíno no Brasil

\begin{tabular}{|l|c|}
\hline Fatores & $\%$ \\
\hline Ração & 64,1 \\
Mão-de-obra & 11,4 \\
Energia & 2,5 \\
Despesa administrativas & 1,5 \\
Medicamentos & 3,7 \\
Veículos (manut. e combustível) & 1,4 \\
Manutenção das instalações & 1,3 \\
Impostos & 7,4 \\
Depreciações & 6,8 \\
\hline
\end{tabular}

Fonte: Elaboração do Autor

Nota: Planilha detalhada no Anexo B

\subsubsection{Produção suinícola}

A fase "dentro da porteira" distingue-se de acordo com a tecnologia utilizada. A produção extensiva cede cada vez mais espaço para a intensificação, gerando, consequentemente, um aumento de produtividade. Na suinocultura, esta produtividade é medida principalmente pelo número de leitões produzidos por matriz anualmente. Considera-se granja de boa produtividade aquela que obtém produção superior a 20 cevados por matriz ao ano.

De acordo com a ABCS (1995), o sul é a região de maior concentração do rebanho suíno nacional, com $36 \%$ do total e 36 milhões de cabeças. Em seguida, vem o sudeste, com $20 \%$. O centro-oeste vem se destacando como o local mais promissor para o desenvolvimento da suinocultura, em vista dos baixos custos de produção, dada a grande oferta de grãos, mas esta atividade é ainda incipiente por lá, representando apenas $12,7 \%$ do plantel brasileiro. O principal motivo para o não desenvolvimento 
maior dessa região está na dificuldade de obtenção de financiamentos bancários, devido ao alto investimento e à não tradição dos empresários rurais daquele local em criar suínos. De acordo com o BNDES, as taxas de juros disponíveis para empréstimos destinados a investimentos na atividade suinícola são de 4 a $6 \%$ ao ano mais a TЛP (taxa de juros de longo prazo), esta considerada muito elevada para o risco que a atividade oferece. Para a região centro-oeste, existe algum tipo de abatimento de até $45 \%$ sobre a TJLP, utilizando recursos do FCO-fundo do centro-oeste.

No Brasil, existem diferentes tipos de criação. O sistema mais comum é o ciclo completo em que todas as fases da produção suinícola se passa na mesma propriedade. Estas são: cobertura, gestação, maternidade, creche, recria e terminação.

A gestação é de 115 dias e, para explorações de alto nível técnico, a desmama é feita em torno 21 dias de idade, quando a leitegada é transferida para a creche. Lá permanece até atingir peso entre 25 e 30 quilos, quando então passa para a fase de engorda (recria e terminação). Os animais ficam nesta fase até alcançarem o peso ideal para abate, em torno de 100 quilos, com aproximadamente 155 dias de idade. Aconselha-se, para novos empreendimentos de maior porte, a utilização de diferentes sítios de criação. Isto é, no primeiro sítio situaria as partes de cobertura e gestação; no segundo, as fases maternidade e creche; e finalmente no terceiro, podendo ser subdividido em múltiplos, a fase final. Este novo processo melhora enormemente o controle sanitário do plantel, fazendo com que sejam obtidos índices técnicos superiores aos sistemas tradicionais, mesmo incorrendo em maiores custos e dificultando um pouco o controle administrativo. Este sistema de múltiplos sítios pode ser feito também com diferentes produtores, havendo especialização por parte de uns com a finalidade específica de produzir leitões e de outros encarregados apenas da fase de engorda.

Outro sistema é o condomínio que surgiu no Estado de Santa Catarina por incentivo da Secretaria da Agricultura, através da ACARESC, nos anos 80. É uma 
sociedade de produtores de determinada região que compram uma propriedade em conjunto e fazem lá as instalações de gestação, maternidade e creche, rateando as despesas. Os leitões são divididos proporcionalmente entre os condôminos que os terminam individualmente. Este sistema proporciona, além de economias de escala em fábrica de ração, redes de energia e água e administração, uma racionalização nas compras de insumos e maior poder de barganha na comercialização da produção. Em um período de transformação da suinocultura nacional, no qual se restringe o número de granjas e aumenta a quantidade de matrizes por criação, esta pode ser uma solução para os pequenos criadores permanecerem na atividade. Em se tratando de uma produção maior do que se executada individualmente entre os sócios, e por ter uma administração mais profissional e não puramente familiar, sua produtividade fica acima da média obtida no Estado de Santa Catarina, chegando a 19 desmamados por porca ao ano. Segundo a ACARESC, em 1993, havia 18 condomínios no estado e, em 1992, este número chegava a 132, com a atuação de 911 membros (Talamini et al., 1995). Em outros estados, como Mato Grosso, este sistema é feito através de cooperativas, sendo denominado de Unidade Produtora de Leitões (UPL) e Unidades Terminadoras (UTs).

Ainda nos estados do sul, principalmente no oeste catarinense, onde se concentram as grandes agroindústrias, os diferentes sistemas de criação normalmente são coordenados por estas empresas. Sua atuação em parceria com o produtor é erroneamente chamada de integração ${ }^{7}$. Para Gomes et al. (1992), este sistema, que teve seu início na década de 30 , é responsável por aproximadamente $40 \%$ do rebanho e por $87 \%$ do abate inspecionado nacional. É no Estado de Santa Catarina que se concentra a grande maioria das empresas que praticam este método, correspondendo a $75 \%$ da produção estadual. O perfil do produtor rural local, formado geralmente por pequenos proprietários utilizadores de mão-de-obra familiar, deu respaldo ao desenvolvimento desta técnica. Gomes et al. (1992) verificaram que esse estado detinha 28.900 “integrados", com uma média de 6,9 matrizes por produtor, número bastante reduzido 
em se tratando de suinocultura modema. A concentração de produção em determinada região, como no oeste catarinense, vem causando, pelo lado ambiental, sérios problemas e, do lado econômico, uma demanda de grãos superior à oferta local. Estas difículdades implicam elevação dos custos, seja em obras de infra-estrutura visando o controle da poluição, seja em transporte de grãos. Estes são sinais claros de saturação da região como produtora de suínos.

A integração pode ser feita de diferentes maneiras. Quando a criação é de ciclo completo é normalmente a agroindústria que fornece o plantel reprodutivo e a ração, seja ela completa ou sob a forma de concentrado caso o produtor tenha seu próprio milho. Quando há divisão entre produtores específicos de leitões e terminadores, a empresa pode até mesmo ser a proprietária dos animais, efetuando sua transferência para quem interessar, restituindo seus "parceiros" de acordo com índices técnicos como porcentagem de mortalidade e conversão alimentar. O preço do produto pago normalmente independe do preço de mercado, mas as empresas encarregam-se de financiar o capital de giro sob a forma de ração e material genético ou até mesmo de instalações físicas. Em ambos os modos de integração, a assistência técnica fica a cargo da agroindústria que, além de opinar no manejo, é responsável pela regulação da oferta da produção de acordo com o planejamento estratégico de seus departamentos de fomento.

Para as agroindústrias, as principais vantagens deste tipo de sistema de comercialização são:

a) Obtenção de matéria-prima padronizada compatível com a automação industrial. $O$ fornecimento de material genético, nutrição e assistência técnica por essas agroindústrias contribui para este fim;

\footnotetext{
${ }^{7}$ Nos capitulos subsequentes, explicitam-se os conceitos técnicos deste tema.
} 
b) Garantia de abastecimento controlando a oferta, visando otimizar as estruturas, reduzindo eventuais períodos de ociosidade;

c) Estabelecimento de preço programável, evitando oscilações bruscas do mercado e consequente descontrole financeiro. Os sistemas de remuneração aos produtores, efetuados pelas empresas, diferem entre si, mas normalmente baseiam-se em outros fatores que não somente os preços vigentes no mercado, tais como indices zootécnicos;

d) Isenção de investimentos em infra-estrutura de produção.

As desvantagens seriam:

a) Alto custo de manutenção da assistência técnica e logística de transporte para as centenas de produtores-parceiros;

b) Dificil controle do alto número de "integrados";

c) Baixa produtividade dos "integrados" de menor porte;

d) Alto custo dos eventuais financiamentos aos "integrados", seja em capital de giro ou em investimento.

Para os produtores, as principais vantagens são:

a) Garantia de venda do produto;

b) Não necessidade de comprar matérias-primas em pequenos volumes e a custos mais elevados;

c) Assistência e informaçōes técnicas e mercadológicas fornecidas pelas indústrias;

d) Financiamento de capital de giro e, às vezes, até investimento em condições favoráveis, fornecidos pelas indústrias.

E as desvantagens seriam: 
a) Reduzido poder de barganha para com as indústrias;

b) Obrigação de entrega do produto final a determinada indústria e a um preço por ela estabelecido, sendo este o principal problema do sistema;

As cooperativas têm atuação semelhante à das integrações, mas seus parceiros são sócios. Com o acirramento competitivo do setor, estão tendo de administrar profissionalmente e acabar com o patemalismo que as diferenciava das outras agroindústrias.

O outro foco de análise são as criações independentes. Este método é adotado em todo o Brasil, com menor ênfase para os estados da Região Sul, onde predominam produtores "integrados" e cooperados. O perfil destes produtores difere bastante dos citados anteriormente. Normalmente, a suinocultura é sua atividade agricola principal. Estes têm a liberdade de adquirir, nos mercados nacional e intemacional, o que de mais moderno encontra-se disponível nas áreas de genética, nutrição e assistência técnica.

Com a tendência de redução das margens para o produtor, os criadores independentes, por sofrerem mais diretamente os impactos do mercado, vêm se aprimorando freneticamente em busca de melhorias técnicas e econômicas ou estão sendo obrigados a sair do mercado.

O preço pago pelo cevado proveniente destas criações tem normalmente como referência as bolsas estaduais ou é discutido pessoalmente com os compradores de frigoríficos. Essas bolsas nada mais são que uma reunião de produtores para debater o comportamento do mercado durante a semana em curso e tentar estipular um preço de consenso e viável para ser praticado pela maioria, levando em consideração a oferta do produto por parte dos produtores e a demanda no atacado e no varejo. A grande 
dificuldade para sua afirmação está na atração da participação dos representantes dos abatedouros, agentes essenciais para a legitimação institucional da bolsa.

Um dos principais gargalos do setor encontra-se fatalmente neste tópico. $\mathrm{O}$ relacionamento produtor-indústria é quase sempre custoso e de difícil acordo. Por este motivo, pretende-se, no decorrer deste trabalho, analisar e sugerir altemativas de comercialização para o setor. Para isto, buscou-se na Nova Economia Institucional o aparato teórico que pode auxiliar na interpretação desta questão.

\subsubsection{Abate e processamento}

A comercialização de suinos é mais complexa que a da maioria dos produtos agrícolas. Por ser um animal sensivel, um manejo pré-abate adequado é essencial e inclui desde transporte em caminhões preparados, embarques e desembarques tranquilos, descanso ao chegar no pátio do abatedouro, além de corredor de linha de abate nas dimensões corretas, até anestesia e sangramento final. Feito o abate, o animal precisa ser desviscerado e sua carcaça desossada e dividida em cortes. Se estas medidas não forem tomadas corretamente, haverá certamente uma variação no $\mathrm{pH}$ da came, levando a problemas como PSE/DFD ${ }^{8}$, que prejudicam a qualidade final do produto. Seu armazenamento é custoso, pois deve ser acondicionado resfriado ou congelado o mais rapidamente possivel, devido à alta perecibilidade e à perda de peso.

A outra opção seria a venda de produtos sob a forma de embutidos. No Brasil, estes atingem aproximadamente $65 \%$ do total das vendas de carne suina segundo o Instituto CEPA/SC. Têm a vantagem de poderem ser armazenados por longos períodos, no caso dos salgados, defumados e curados, ou transformados em variada gama de produtos de baixo custo, devido à utilização complementar de condimentos, gordura $\mathrm{e}$ água. O problema é que nem sempre este reduzido valor agregado chega ao consumidor 
final. Industrializados de carne são considerados produtos de luxo no Brasil e, por isto, ainda extremamente caros em comparação a outros países mais desenvolvidos. Outros autores já observaram este problema e o descreveram da seguinte maneira:

A industrialização permite adicionar a matéria-prima carne, diferenciar mercadologicamente os produtos, ter períodos mais longos para a comercialização, aproveitar melhor as gorduras das carcaças etc.. Mas, devido ao maior preço dos produtos industrializados, apenas uma pequena proporção da população com renda alta tem acesso a estes produtos. Segundo especialistas, isto tem restringido o crescimento da produção de suínos, uma vez que não estão sendo exploradas as possibilidades de consumo da carne in natura (Talamini et al., 1995, p.8).

A qualidade da carne passa a ser cada vez mais importante com a maior exigência dos consumidores. A melhor maneira de transferir esta responsabilidade para os produtores é classificar as carcaças. Alguns abatedouros já implantaram esta técnica, que funciona de maneira eletrônica, com a utilização de uma sonda calibrada para medir a quantidade de carne magra contida em cada carcaça e de outra que mede o $\mathrm{pH}$ da mesma. O objetivo desta classificação é incentivar o aperfeiçoamento técnico de criação, estimulando melhoras genética, nutricional e de manejo. Para isto, paga-se diferenciadamente pelas carcaças de melhor qualidade, beneficiando-as e penalizando as piores. Esta atitude diminui o problema de assimetria de informações nesta transação, pois passa a haver uma comercialização mais transparente e com regras preestabelecidas.

Na Região Centro-Sul, concentram-se $91 \%$ dos frigoríficos brasileiros, ou seja, aproximadamente 270 unidades de abate e processamento com inspeção federal, segundo o Sindicato da Indústria do Frio - Sindifrio.

${ }^{8}$ PSE (pale, soft and exdrusive) pálida, mole e exsudativa e DFD (dark, flacid e dry) escura, flácida e seca. 
O setor de abate pode ser claramente dividido em três grupos. O primeiro é formado pelas poucas e grandes agroindústrias frigorificas, entre elas: Sadia, Perdigão, Ceval, Aurora e Chapecó. Estas detêm um significativo poder de mercado devido a seu volume de compra. Tomando como unidade de medida o número de suínos abatidos individualmente por estas empresas, pode-se calcular esta concentração através de valores como a razão de concentração das $r$ maiores empresas $\left(C_{r}\right)$. O $C_{4}$, isto é, a participação no abate das quatro maiores empresas é de $33,2 \%$, o que corrobora a afirmação. A Tabela 2 apresenta a divisão deste mercado por empresa.

Estas agroindústrias, praticantes do sistema de parceria, processam praticamente toda a produção abatida, só vendendo eventualmente alguns cortes especiais congelados. Possuem processos industriais modernos e automatizados e estão preparadas para colocar seus produtos em qualquer região do país e do mundo, caso revoguem-se as barreiras não-tarifárias. Passam atualmente por um processo de reestruturação nos comandos, transferindo o controle para mãos de executivos profissionais em detrimento das tradicionais administrafões familiares. Espera-se que este processo dê maior vigor competitivo a estas companhias.

Tabela 2: Abatedouros de suínos e suas participações no mercado nacional em 1994

\begin{tabular}{|l|c|c|}
\hline \multicolumn{1}{|c|}{ Empresas } & Participação no Mercado & $\begin{array}{c}\text { Suínos abatidos } \\
\text { (em mil cahecas) }\end{array}$ \\
\hline Sadia & (em \%) & 1.440 \\
Perdigão & 11,4 & 1.120 \\
Ceval & 8,9 & 845 \\
Coopercentral & 6,7 & 780 \\
$\quad$ (Aurora) & 6,2 & \\
Chapecó & 4,1 & 520 \\
Outros & 62,7 & 7.915 \\
Total & 100 & 12.620 \\
\hline
\end{tabular}

Fonte: Setor Agroindustrial do BNDES e Centro de Informações da Gazeta Mercantil 
O segundo grupo é formado por pequenos e médios frigoríficos de atuação regional (Tabela 3). Estes continuam, em sua grande maioria com administrações familiares, tentando agir aproveitando-se da assimetria de informações e utilizando "malabarismos" fiscais. Vários destes tiveram de encerrar suas atividades recentemente, mas os que passaram por este processo seletivo mostraram ser realmente competentes, independentemente dos métodos utilizados para sua sobrevivência.

Tabela 3: Diferenciados grupos de abatedouros no Brasil

\begin{tabular}{|c|c|c|c|}
\hline Grupo & Capacidade de abate & Tipos de produto & Mercado \\
\hline 1 & $>1.000$ cabeças/dia & Praticamente & Nacional e exportação \\
2 & Entre 100 e 1.000 cab./dia & Carcaças e cortes & Regional \\
3 & $<100$ cabeças/dia & Carcaças & Local \\
\hline
\end{tabular}

O terceiro tipo que é necessário destacar é o abate clandestino. Seu índice de significância varia de acordo com a região, indo de pouco mais de $15 \%$ na Região Sul à quase totalidade no norte e no nordeste. Mas, em todo o território nacional, este processo ainda tem enorme importância, mesmo não sendo suportado com estatísticas confiáveis. É um dos responsáveis pela deterioração da imagem da came suína, por frequentemente possuir instalações inadequadas de abate e refrigeração. Está incluído neste o abate para subsistência, grande responsável por fornecer proteína a boa parte da população rural do país.

\subsubsection{Distribuição}

A partir do abate, a carcaça pode ser resfriada para venda aos estabelecimentos comerciais ou desossada e preparada em cortes no próprio frigorífico, e só então ser distribuída aos varejistas. Pode ainda ser industrializada para posterior venda sob a forma de embutidos. Durante todo este processo, é demandada uma série de bens 
complementares e serviços, tais como condimentos e embalagens, além de todo o trabalho de logistica.

A came segue então seus dois destinos básicos, mercado interno ou exportação. Em ambos, o objetivo é o mesmo: atingir de maneira satisfatória o consumidor final que adquire o produto em supermercados, feiras, açougues e restaurantes.

No Brasil, ainda persiste o hábito de adquirir carne em açougues de bairro, devido ao atendimento personalizado e ao preço. Estes, de maneira geral, ainda apresentam e acondicionam muito mal o produto. Observa-se, porém, que as vendas nos super e hipermercados vêm aumentando sua participação a cada ano, principalmente nas médias e grandes cidades. A praticidade e a boa apresentação contribuem para o crescimento nestes pontos. Este processo já aconteceu nos paises desenvolvidos que também tinham tradição de vendas de carne em açougues. Na França, por exemplo, segundo o ITP (1993, p.14), em 1980, 50\% de toda a came suína eram comprados nos super e hipermercados. Este número passou para 75\% em 1992.

Segundo o Sindifrio, a rede de distribuição reúne aproximadamente $55 \mathrm{mil}$ açougues e empregam 165 mil trabalhadores, sem incluir ai os supermercadistas, que possuem mais de 35 mil pontos de venda. Acredita-se que ainda $60 \%$ das vendas de came no Brasil ainda sejam realizadas em açougues e feiras, e somente $40 \%$ nos supermercados. Observa-se que os preços, nestes estabelecimentos varejistas, ainda são bastante superiores aos dos açougues, mas esta prática pode mudar, uma vez que o poder de barganha comercial dos super e hipermercados é muito maior que o dos açougues, devido principalmente ao volume de compra e à garantia de pagamento.

Alguns supermercados começam a interessar-se em fazer algum tipo de contrato de fornecimento de came com determinados frigorificos para recebimento já desossada e embalada. As vantagens, segundo o diretor comercial de perecíveis do grupo Pão de 
Açúcar, Wilson Barquilla, são: não mais transportar carne com osso, que é antihigiênico e mais caro; gerar economia de espaço nas lojas; ter maior limpeza e melhor aproveitamento do funcionário que antes se ocupava da desossa. Estes fatores levaram grupos varejistas como o Pão de Açúcar a adotarem esta regra.

Para apressar este processo e tentar coibir o abate clandestino, a Secretaria de Defesa Agropecuária do Ministério da Agricultura publicou, em abril de 1996, a Portaria 304, que diz em seus primeiros artigos:

Artigo $1^{\circ}$ : Os estabelecimentos de abate de bovinos, bubalinos e suínos somente poderão entregar carnes e miúdos, para comercialização, com temperatura de até sete graus centígrados.

Par. $1^{\text {o. }}$ : As carnes de bovinos e bubalinos somente poderão ser distribuídas em cortes padronizados, devidamente embaladas e identificadas.

No entanto, esta portaria ainda não obriga à desossa da came. Esta idéia foi cogitada, mas, como em várias regiões do país há o hábito de consumir carne com osso, este item foi retirado. É importante destacar também que, no parágrafo primeiro, foi excluída a carne suína, mas apenas em primeira instância, para dar condições e tempo para adaptações, pois tem-se a intenção de inclui-la brevemente.

A dificuldade da prática desta portaria está na fiscalização, pois o grande número de pontos que comercializam este produto dificulta esta atuação.

Entende-se, no entanto, que esta iniciativa não deveria partir de uma arbitrariedade governamental, pois é, sem dúvida, uma tendência natural em busca da eficiência na coordenação do sistema como um todo, denominado de competitividade neste estudo. 
É no agente referente à distribuição que se encontra um importante entrave ao aumento do consumo da carne suína. Mesmo não sendo o cerne deste trabalho, é pertinente destacar a importância do marketing do produto sob a forma de consumo in natura, ficando a idéia como sugestão para futuros trabalhos nesta área de atuação.

A carne suína tem uma péssima imagem perante a opinião pública nacional. A idéia de uma carne gordurosa com altos teores de colesterol e transmissora de doenças como a cisticercose ainda persiste ${ }^{9}$. É para essa desmistificação que se deve buscar implantar, o mais rapidamente possivel, uma ampla campanha de esclarecimento. $\mathrm{O}$ desconhecimento do público consumidor dos novos tipos de criação, abate e processamento da came suína é que leva à persistência desta imagem, que não condiz com a realidade atual.

Esta publicidade deveria ser financiada proporcionalmente pelos agentes envolvidos no sistema, pois todos se beneficiariam. O problema é que sempre surge a presença do caroneiro ou “free-rider":aquele que se beneficia de uma vantagem pública, mas esquiva-se das despesas. A presença desses oportunistas dificulta o processo.

Após a descrição do setor subdividido entre os agentes atuantes do sistema, devese destacar que o período transitório por que passa a economia brasileira pode modificar rapidamente este perfil. No âmbito do agribusiness, no qual o sistema suinícola também se encontra, "toda a geografia da produção primária e locacional das plantas industriais está em xeque, assim como as relações verticais entre segmentos constituintes das cadeiras produtivas". As privatizações e concessões ao setor privado dos setores energético, de telecomunicações, e principalmente da malha de transportes contribuirão certamente para $o$ aceleramento destas mudanças.

\footnotetext{
${ }^{9}$ Existem inúmeros trabalhos com o intuito de provar que a carne suína produzida atualmente não pode ser considerada a vilã das carnes, seja em termos de gordura, nível de colesterol ou transmissão de doenças.
} 


\section{REFERENCIAL TEÓRICO}

Com a finalidade de testar as hipóteses delineadas anteriormente, buscou-se um arcabouço teórico que as justificasse. Encontrou-se o aparato necessário na teoria das margens de comercialização para provar que a questão preço ainda é significativa nas quantidades de came suína produzida e consumida no Brasil. Por outro lado, a Nova Economia Institucional, apoiada também nas questões não-preço, surge para lidar com objetos em que a análise qualitativa torna-se mais relevante, justificando a coordenação como fator de competitividade.

\subsection{A Nova Economia Institucional (NEI)}

A complexidade e os riscos de efetuar transações entre firmas, em um mundo cuja economia encontra-se cada vez mais globalizada e competitiva, geram custos crescentes de elaboração e monitoramento de contratos a fim de evitar custos de rompimentos contratuais.

Os estudos sobre o tema relacionado a questão contratual entre firmas iniciaramse com Coase (1937), que procurou dar um enfoque diferente às firmas. Estas deixariam de ser estudadas como simples unidades de transformação de bens e serviços e passariam a ter o contexto de "complexo de contratos regendo transações internas".

O autor introduz a idéia da Economia dos Custos de Transação (ECT), na qual se estuda como os agentes transacionam e se protegem dos riscos, sendo esta teoria uma importante parte da Nova Economia Institucional (NEI). Estes custos não estariam 
relacionados diretamente à produção e poderiam ser divididos em duas espécies: custos de coleta de informações e custos de negociação e estabelecimento de um contrato.

Posteriormente, Williamson (1993) definiu custos de transação como "os custos ex-ante de preparar, negociar e salvaguardar um acordo bem como os custos ex-post dos ajustamentos e adaptações resultantes quando a execução de um contrato é afetada por falhas, erros, omissões e alterações inesperadas. Em suma, são os custos de conduzir o sistema econômico".

Mas, o paradigma central sugerido por Coase ainda persiste e seria a resposta de "make-or-buy decision", isto é, o que seria mais interessante para a firma, comprar no mercado ou produzir ela mesma internamente?

Esta teoria sustenta-se sobre os alicerces do oportunismo e da racionalidade limitada. Pressupõe-se que os agentes econômicos sejam racionais, mas que esta racionalidade seja limitada, pois não é possível prever, no momento da negociação, tudo o que poderá ocorrer em um contrato de longo prazo. Assim, pode-se dizer que qualquer relação contratual é intrinsecamente incompleta. Já o oportunismo é obtido pela utilização de algum proveito da assimetria de informações para uso próprio. $\mathrm{Na}$ ausência destes pressupostos comportamentais, os problemas econômicos relativos à contratação não seriam significantes, pois toda relação comercial funcionaria perfeitamente.

Deste modo, o indicativo básico da Economia dos Custos de Transação seria a existência de custos diferentes de zero ao efetivar transações. Estes seriam influenciados de acordo com a existência de diferentes arranjos institucionais que ocorrem em um ambiente institucional ${ }^{10}$ estruturado. Pode-se dizer, então, que as instituições ${ }^{11}$ interferem nesses custos. ${ }^{10}$ Para Furubotn \& Richter (1991, apud Zylbersztajn 1995, p. 17), ambiente institucional são sistemas de
normas que afetam o processo de transferência de direitos de propriedade, exigindo recursos reais para 
No Brasil, Zylbersztajn (1995), corroborando os trabalhos de Williamson, coloca a ECT como a base analítica para o estudo de formas organizacionais de produção, buscando relacionar os atributos típicos das transações com as formas de organização mais eficientes em termos de economia de custos de transação e produção. Essas formas podem ir da produção via mercado até o extremo da integração vertical, passando intermediariamente pelas formas híbridas ou contratuais mais ou menos rígidas.

Para o mesmo autor, o objetivo fundamental da NEI ou da ECT é "estudar as transações como o indutor dos modos alternativos de organização da produção dentro de um arcabouço analítico institucional". Ele ainda propõe que a ECT possa prover importante suporte teórico para o entendimento de sistemas do agribusiness, expandindo o campo analítico tradicional. Por isso, deve-se considerar que as transações acontecem conectando os agentes envolvidos nos sistemas, partindo da indústria de insumos e chegando até o consumidor final (Figura 6).

Ambiente Institucional: Cultura, Tradições, Educação, Costumes.

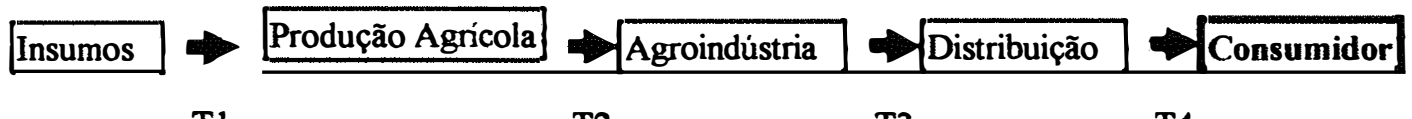

T1 $\mathrm{T} 2$ T3 $\mathrm{T} 4$

Ambiente Organizacional: Associações, Sindicatos, Firmas, Cooperativas.

Fonte: Zylbersztajn (1995, p. 173)

Figura 6 - Sistema de Agribusiness e transações típicas

Os quatro tipos de transações gerais são definidos como Ti. A primeira $\left(\mathrm{T}_{1}\right)$ é realizada entre a indústria de insumos e o produtor rural propriamente dito. Nesta,

operarem. Williamson (1993, p.6) diz que é um conjunto de regras políticas e sociais que estabelecem a base de produção, troca e distribuição.

${ }^{11}$ Segundo North (1991, p. 97), instituições são normas constituidas pelos homens. Elas consistem em restrições informais (tabus, costumes e códigos de conduta) e regras formais (leis, direitos de propriedade). 
enquadram-se as indústrias de fertilizantes, medicamentos, genética, nutrição e equipamentos, entre outras. Transações via mercado são mais frequentes na relação entre indústrias de fertilizantes e medicamentos, enquanto que na área de genética e nutrição, a relação contratual torna-se cada vez mais marcante.

A segunda $\left(T_{2}\right)$ passa-se entre produtores rurais e agroindústrias, cujo relacionamento é o principal ponto do desenvolvimento deste trabalho. Acredita-se estar contido nessa transação um dos importantes gargalos na comercialização dos produtos agrícolas. Essas transações são efetuadas no mercado caso o bem seja "commoditizado", mas, em se tratando de produtos mais específicos, isto é, caso a especificidade dos ativos $(k)$ seja elevada, esta relação tende a efetivar-se através de contratos mais ou menos rígidos ou até mesmo integrando-se verticalmente. Esta integração pode ser feita para frente, no caso do produtor atuar também como industrial, ou para trás, quando o industrial passa a deter a produção agrícola com o objetivo de fornecer matéria-prima à sua agroindústria.

Quanto ao $\left(\mathrm{T}_{3}\right)$, interface da agroindústria e da distribuição, é de extrema importância para uma boa eficiência do sistema. Existe uma tendência dos grandes distribuidores passarem a atuar mais próximos de seus fornecedores, seja integrando-se parcialmente, adquirindo participações acionárias dos dois lados ou mesmo elaborando algum tipo de contrato de fornecimento cada vez mais rígido. Esta tendência é certamente reflexo da capacidade que as redes de supermercados têm de identificar as reações dos consumidores frente a novos lançamentos, podendo posteriormente transferir essas informações para os segmentos antecedentes ao sistema. Estes, por sua vez, serão assim capazes de reformular mudanças estratégicas em seus produtos a fim de buscar a maximização da satisfação dos consumidores.

Por fim, a quarta transação $\left(\mathrm{T}_{4}\right)$ indica a relação entre distribuição e consumidor. Encontram-se, aqui, os trabalhos voltados para a área de marketing. A preferência do 
consumidor vem se alterando de maneira muito rápida quanto ao local de compra. Mudanças no padrão de renda, processos migratórios e urbanização vêm contribuindo para que isso aconteça. Existe uma clara tendência de substituição dos pequenos estabelecimentos varejistas em detrimento dos hiper e supermercados. A diferença de preço e a comodidade de encontrar maior variabilidade de produtos incentivam a essa mudança. Por outro lado, o tratamento pessoal e específico perde espaço para o impessoal dos grandes estabelecimentos.

\section{Especificidade dos Ativos}

A importância do entendimento da especificidade dos ativos $(k)$ é essencial na compreensão do estudo da ECT. Para Riordan \& Williamson (1985, p. 367), suas variações são o principal fator determinante das diferenças de custos de transação.

Ativos específicos são aqueles que somente são reempregáveis em uso alternativo com alguma perda de valor. Ativos não-específicos têm grande flexibilidade de utilização alternativa, podendo adaptar-se facilmente às eventuais externalidades. A definição utilizada por Williamson (1991, p. 281) é "o grau segundo o qual um ativo qualquer pode ser realocado para usos alternativos, por usuários alternativos, sem prejuízo do seu valor produtivo". Quanto maior a especificidade dos ativos, maiores serão os riscos e, consequentemente, os custos de transação.

Williamson (1991, p. 105) define seis tipos principais e não-únicos de especificidade dos ativos:

a) Especificidade local, pois a proximidade das firmas pode trazer economia em nível de logística ( transportes e armazenamento), partindo da análise do seu custo de remodelação e realocação; b) Especificidade física dos ativos, quando uma ou ambas as partes envolvidas na transação fazem investimentos em máquinas e equipamentos que 
envolvem características específicas e que têm valores mais baixos em usos alternativos; c) Especificidade humana, como investimentos em treinamento especifico para exercer determinada função; d) Ativos dedicados, quando se dedica determinado investimento em ativos a compradores específicos, sendo que, se o contrato for quebrado prematuramente por alguma razão, deixará o fomecedor com significativo excesso de capacidade; e) Especificidade de marca, que se refere ao capital excluindo o fisico e o humano; f) Especificidade temporal, relacionada à perecibilidade do produto, dependendo do tempo necessário à realização da transação.

Masten (1994, p. 7) destaca a importância de diferenciar ativo específico (ativo que produz o produto somente para um cliente em particular) de ativo especializado (aquele que pode produzir somente um único produto).

\section{Estrutura de Governança}

Williamson (1993) define estrutura de governança como uma matriz institucional em que é definida a integridade das transações. Existem três formas organizacionais ou estruturas de governança principais: mercado, híbrida ou integrada verticalmente.

A forma de organização via mercado é a mais simples, caracterizada por um baixo custo de monitoramento. Ocorre basicamente por meio do sistema de preços e será sempre preferida quando a especificidade dos ativos for baixa. Nesse caso, uma transação na qual a identidade das partes envolvidas é irrelevante, não havendo qualquer dependência entre os lados envolvidos. Segundo Zylbersztajn (1995, p. 78), é tipicamente determinada por elevado grau de incentivo para os agentes envolvidos na transação, entretanto, face a um ambiente conturbado, sua adaptabilidade pode ser menor, levando à busca de outras formas que melhor possam lhe convir. Os custos burocráticos, reduzidos em se utilizando o mercado como parâmetro, elevam-se à medida que se altera a direção para organizações via firma ou integração. 
A integração vertical ou forma hierárquica existe quando a firma decide internalizar o segmento de atividades que vem imediatamente a jusante ou a montante de sua atividade principal (integração para frente upstream ou para trás downstream), compreendendo a propriedade total dos ativos envolvidos. Dificuldades em redigir e monitorar um contrato de longo termo que pode responder eficientemente a mudanças de condições de mercado no tempo podem implicar custos que fariam tender a balança em direção da integração vertical.

Esta forma é considerada a mais privilegiada quanto à capacidade de adaptação. Pode ser bem sucedida quando as transações não permitem o uso do mercado, servindo de alternativa a essa forma. O problema é determinar quando a firma deve internalizar ao invés de adquirir de terceiros.

Formas extremas de organização, via mercado e interna (integração vertical), não representam todo o universo produtivo. Existem também as formas hibridas ou contratuais, que se situam entre as extremas. Aplicam-se a contratos nos quais as partes envolvidas na transação mantêm sua autonomia, mas são bilateralmente dependentes. Os custos administrativos e burocráticos são inevitáveis e se situam em um nível intermediário entre o mercado e a solução interna. Estas formas podem ser mais ou menos rígidas, dependendo do grau de arbitraniedade a que as partes envolvidas se sujeitam.

\section{Modelo}

"Com os custos referentes a quebras contratuais de longo prazo aumentando, o controle interno passa a ser mais atrativo. Isto sugere que, se nós pudermos achar uma maneira de medir variações na escolha de Estrutura de Governança e relacionando estas 
com o grau associado de especificidade dos ativos, nós estaremos no caminho de nos tornarmos capazes de testar esta teoria empiricamente" (Joskow, 1991, p. 122).

Apoiando-se no oportunismo e na racionalidade limitada como pressupostos comportamentais $^{12}$ servindo de variáveis exógenas e utilizando a especificidade dos ativos como principal instrumento no dimensionamento das transações, Williamson propõe um modelo que trata da relação de eficiência das formas organizacionais como função da especificidade dos ativos.

O modelo é montado tendo como referência a comparação entre os três mecanismos de governança, sendo as variáveis endógenas ao modelo e considerando as diversas formas organizacionais da produção de maneira contínua, partindo da pura transação spot (via mercado) até as totalmente hierarquizadas ou integradas verticalmente. Assim sendo, as condições em que a firma opera é que permitirão concluir pela melhor forma de relação entre as formas citadas.

Considerando a existência de custos de transação diferentes de zero, considerase, consequentemente, a possibilidade de obtenção de valores crescentes para especificidade dos ativos $(k)$. Deste modo, muitas transações que, com baixos valores de $k$, poderiam acontecer via mercado passariam a tender progressivamente a ser retiradas do mercado e internalizadas na firma.

Para a finalidade deste trabalho, não se pretende decifrar e desenvolver o modelo, mas apenas aplicá-lo no contexto do tema proposto. Será utilizada a adaptação adotada por Azevedo (1996, p. 65) na forma reduzida do modelo elaborado por Williamson (1991), descrito a seguir.

12 Para maiores esclarecimentos sobre as terminologias relacionadas à NEL, ver na literatura brasileira: Zylbersztajn (1995), Azevedo (1996) e Jank (1996). 
Com o intuito de comparar as diferentes formas organizacionais, define-se uma função de custos de governança da transação para cada uma. Os parâmetros apresentados são a especificidade dos ativos e um vetor de deslocamento das funções como incerteza e ambiente institucional - como garantia dos direitos de propriedade. Admite-se também um dado nível de produção $(k)$ constante e que os custos de produção sejam iguais em todas as formas.

As funções são então representadas da seguinte maneira:

$M(k, \theta)$ para a função que representa custo de governança da forma organizacional de mercado;

$X(k, \theta)$, função representando o custo via forma híbrida; e

$H(k, \theta)$, função da forma hierárquica, onde $\boldsymbol{k}=$ especificidade dos ativos e $\theta=$ vetor de parâmetros de deslocamento.

Sabendo que o mercado promove adaptações mais eficientes quando as especificidades dos ativos tendem a zero, tem-se:

$$
M(0, \theta)<X(0, \theta)<H(0, \theta)
$$

Azevedo (1996, p. 66) explica que, para um nível de especificidade nulo, o mercado é sempre mais eficiente que a hierarquia e a forma híbrida. Além disso, conforme aumenta a especificidade dos ativos, o mesmo acontece com a dependência bilateral e, portanto, com a necessidade de controle. Assim, os custos do mercado elevam-se relativamente mais à medida que aumenta a especificidade dos ativos. Zylbersztajn (1995, p. 90) descreve que “o modelo representa também a inadequação dos mercados e progressivamente a capacidade das formas híbridas e hierárquicas em lidarem melhor com as necessidades de adaptação advindas da característica de 
rompimentos contratuais. Esta característica fica evidenciada pela representação de declividade de cada curva a um dado nível de $k$ ", ou seja;

$M^{\prime}>X^{\prime}>H^{\prime}>0$, i.e. $\partial M \partial K>\partial X \partial K>\partial H \partial K$

onde o apóstrofo representa a derivada da função com relação a $k$.

Deste modo, constrói-se a Figura 7, que representa os custos de governança variando em função da especificidade dos ativos $(k)$, mantido constante o vetor $(\theta)$ de parâmetros de deslocamento.

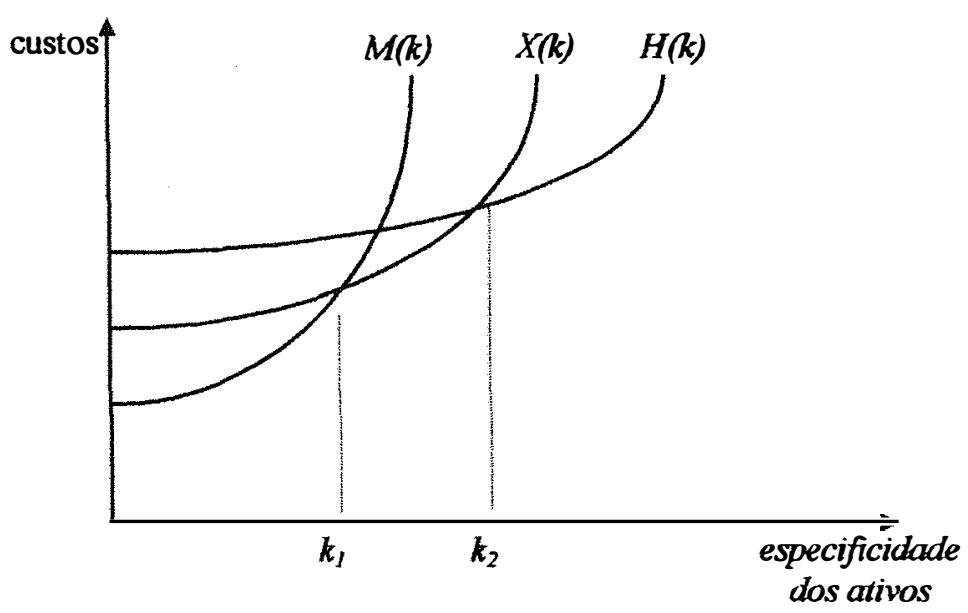

Figura 7 - Especificidade de ativos e mecanismos de governança

O nivel de especificidade $k_{l}$ situa-se em um ponto em que os agentes são indiferentes na escolha entre as formas organizacionais de mercado ou híbrida; o mesmo ocorre no ponto $k_{2}$, em que há indiferença entre as formas híbridas e hierárquica. Assim, pode-se traçar uma "curva envelope" análoga à curva de custos médios de longo prazo da microeconomia, associando especificidade dos ativos a custos de governança dada a escolha ótima da forma organizacional, ou seja, definindo uma fronteira de eficiência de custos mínimos. Deste modo, o ponto ótimo escolhido estará sempre sobre esta "curva envelope". Nestes casos, a forma organizacional de melhor uso alternativo dadas as 
condições locais será: mercado, se $k^{*}<k_{1}$, forma híbrida, se $k_{1}<K^{*}<k_{2}$; e hierárquica, se $k^{*}>k_{2}$.

\subsubsection{Competitividade na visão da Nova Economia Institucional}

Com a irreversível abertura de mercado efetivando-se em todo o mundo, assim como no Brasil, o termo competitividade volta a ser o centro das discussões. Resumindo as inúmeras definições, pode ser descrito como a capacidade de sobreviver e crescer.

Mesmo reconhecendo toda a polêmica em torno desta terminologia e o impasse em adotar um termo apropriado, optou-se pela afirmação referente à Nova Economia Institucional por bem adequar-se ao tema proposto de Sistemas Agroindustriais. Esta opção não implica qualquer discordância sobre outras, mas sim, uma abstenção à entrada no mérito da evolução histórica ou na definição de melhor respaldo sobre competitividade.

Segundo Farina et al. (1997, p. 3), grosso modo, pode-se dividir a competitividade de determinado sistema agroindustrial em dois grandes blocos:

1. produtiva/tecnológica: relacionada a custos de produção, diferenças de produtividade e aspectos de logística;

2. coordenação: capacidade de receber, processar, difundir e utilizar informações de modo a definir e viabilizar estratégias competitivas (inovação de produto e processo, diferenciação, segmentação, etc.), efetuar controles, e reagir a mudanças no meio ambiente.

Os componentes descritos no primeiro bloco são quantificáveis e mensuráveis. Já o segundo bloco é constituído de variáveis de caráter qualitativo, nem sempre passíveis 
de quantificação, mas certamente tão importantes quanto as do primeiro. Ainda assim, é desejável que se construam indicadores para a capacidade de coordenação. É neste segundo item que se concentra este estudo.

A capacidade de coordenação (estruturas de govemança adotadas) é o determinante do sucesso das estratégias das firmas. Esta ainda depende do ambiente institucional (basicamente políticas macroeconômicas) em que está inserida e do apoio complementar do ambiente organizacional e tecnológico como mostrado na Figura 8, extraída de Farina et al. (1997, p. 9). 


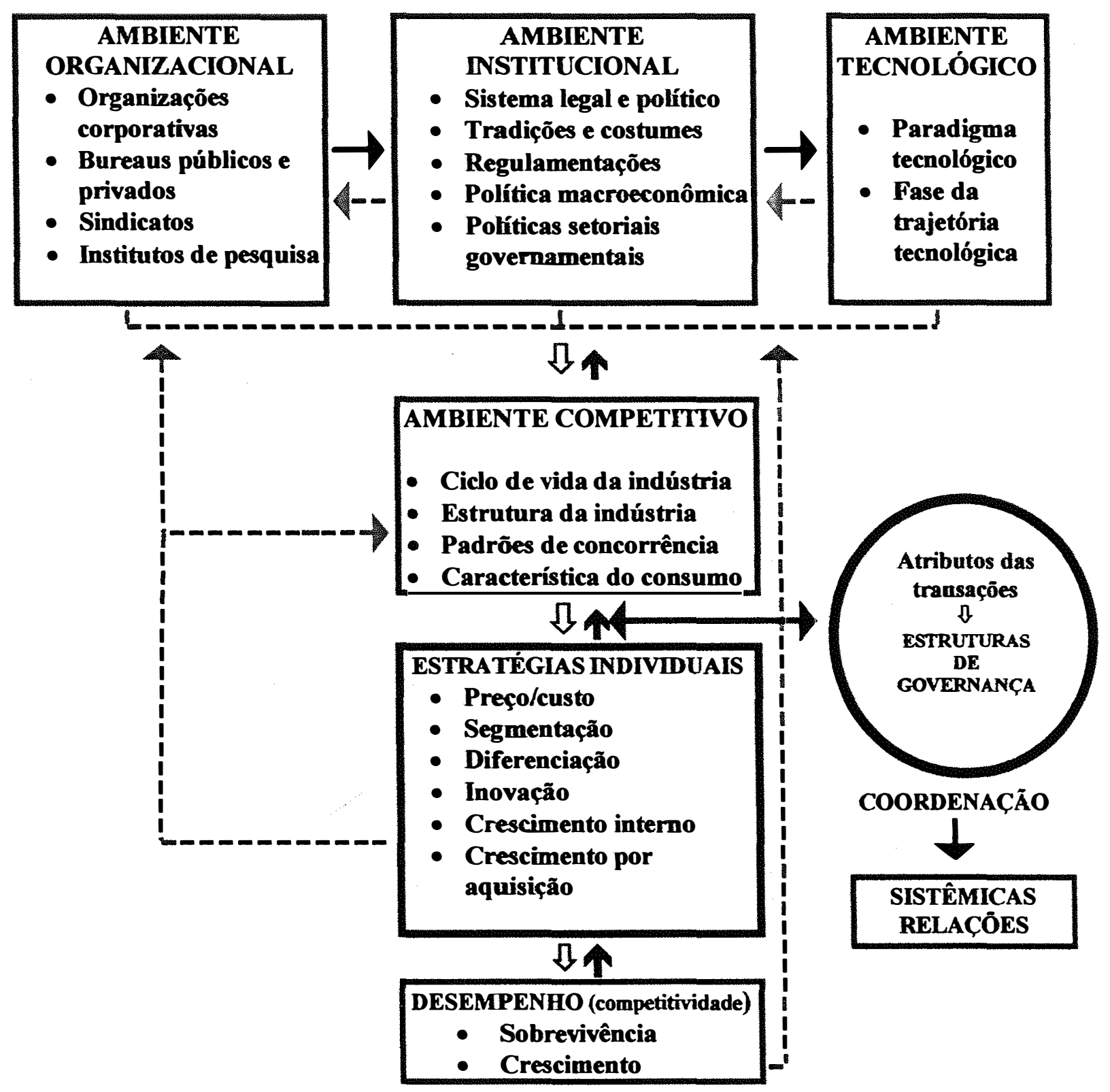

Figura 8 - Estrutura conceitual de competitividade 
Problemas econômicos surgem sempre em consequência de mudanças. A preocupação gira, então, em torno da adaptação a essas mudanças, pois elas geram oportunidade de lucro àqueles que mais rapidamente se adaptarem.

Segundo Williamson (1991, p. 102), existem dois tipos de adaptação: o denominado tipo A, indicando autonomia, em que consumidores e produtores respondem independentemente a mudanças nos preços a fim de maximizar suas utilidades e seus lucros respectivamente, isto é, uma parte pode responder eficientemente sem consultar a outra, com a pura participação do mercado para resolver o problema.

Distúrbios tornam-se mais complicados quando se tem dependência bilateral e o mercado já não é mais suficiente para solucioná-los. A adaptação toma-se, então, cooperada ou representada pelo tipo $\mathbf{C}$.

A questão central passa a ser a busca da eficiência que tem como definição "a forma organizacional que viabiliza a coordenaçāo ${ }^{13}$ das etapas sequenciais do processo produtivo. Eficiência, neste contexto, transforma-se na capacidade de resposta que, por sua vez, reflete uma estratégia minimizadora de custos de produção, distribuição e transação" (Farina \& Zylbersztajn, 1994, p. 7).

Seriam considerados competitivos, então, os sistemas que conseguissem aliar estruturas tecnológicas eficientes, como minimizar custos de produção, com estruturas economizadoras de custos de transação, levando em consideração principalmente sua capacidade adaptativa em cada ambiente institucional. Assim, com o aumento do nível de especificidade dos ativos, a necessidade de cooperação para permitir tais adaptações toma-se essencial, pois a redução da eficácia na adaptação eleva os custos de transação. 
Deste modo, considerando os tipos de domínio existentes, regidos sob determinado aparato institucional, é possivel buscar as estruturas de governança de melhor dinamismo adaptativo. Em se analisando o modelo proposto, esta "melhor forma" encontra-se na referida "curva envelope", dependendo do nivel de especificidade dos ativos.

\subsection{Margens de Comercialização}

No clássico trabalho desenvolvido por Junqueira e Canto (1971, p. 4), estes afirmam ser comercialização o sistema que procura ter a certeza de que os bens e serviços produzidos por empresas privadas reflitam bem as preferências do consumidor. Comercialização pode ser definida como o conjunto de atividades realizadas pelas instituições responsáveis na transferência de bens e serviços da produção inicial até o consumidor final.

Barros (1987) e Marques \& Aguiar (1993) afirmam que a comercialização realiza uma série de funções através das quais bens e serviços são transferidos dos produtores aos consumidores, sofrendo transformações mediante utilização de recursos produtivos (capital e trabalho) que atuam sobre a matéria-prima agrícola, tratando-se de um processo de produção ${ }^{14}$ como outro qualquer, adicionando utilidade. Essas transformações podem envolver alteração da forma da matéria-prima, do tempo (armazenamento) ou ainda espacial, levando em conta os transportes. As firmas que realizam essas tarefas recebem remuneração pelos serviços prestados encarregando-se de colocar o produto à disposição do consumidor nos desejados local, época e forma.

\footnotetext{
${ }^{13}$ A coordenação, aqui, refere-se à fluência de informaçỏes, incentivo e controle do mercado para os segmentos constituintes. Isto é, transmissão de informações ao longo do sistema produtivo, respondendo a quaisquer externalidades.
} 
Entre o produtor rural e o consumidor final existe um conjunto de agentes intermediários. Quando estes exercem suas atividades, incorrem em despesas denominadas custos de comercialização. Segundo Briz \& de Filipe (1997), custos de comercialização são distinguidos de custos de produção pelo ponto que os separa, que é a porteira da fazenda. Despesas geradas dentro da porteira são consideradas custos de produção enquanto as efetuadas depois da porteira, custos de comercialização. Estes nada mais são que o retorno da utilização dos fatores de produção. São de difícil mensuração por envolverem uma série de dados detalhados relacionados a transportadores, armazenadores e das agroindústrias. Opta-se, assim, por trabalhar com margens.

Junqueira e Canto (1971) afirmam que o cálculo da margem dá-se pela diferença entre o preço pelo qual um conjunto de intermediários vende uma unidade do produto $\mathrm{e}$ o pagamento que faz pela quantidade equivalente que precisa comprar para vender essa unidade. A quantidade equivalente pode ser maior que a quantidade vendida, devido às perdas advindas tanto do amassamento como de podridão ou processamento. Quando algum subproduto é obtido na indústria, o pagamento pela quantidade equivalente é ajustado pela subtração do valor a ele imputado. Grosso modo, a margem é definida como $M=C+L$, onde (C) são os custos e (L), o lucro ou o prejuizo dos intermediários.

A Margem Total Absoluta (MT) mede os gastos do consumidor no processo global de comercialização, sendo a diferença entre o preço do varejo $(P v)$ e o preço pago ao produtor pela quantidade equivalente na fazenda $(P p)$, após o ajuste descontando os subprodutos e eventuais perdas. É uma grande parte do custo total do varejo dos produtos agrícolas.

\footnotetext{
${ }^{14}$ Segundo Mighell \& Jones, citados por Barros (1987), produção é qualquer atividade que resulte na criaf̧ão de utilidade de forma, espaço ou tempo.
} 
A $M T$ é identificada pela distância vertical no equilíbrio de mercado ou na interseção das curvas de oferta e demanda nos diferentes estágios de comercialização (fazenda, atacado e varejo), como demonstrado na Figura 9. Obtém-se o valor monetário da margem de comercialização multiplicando a margem total absoluta pela quantidade comercializada, isto é, MT = Qo (Pv-Pp). Pressupondo quantidade constante (Qo) para os diferentes níveis de preços, este valor é representado pela área PpACPv.

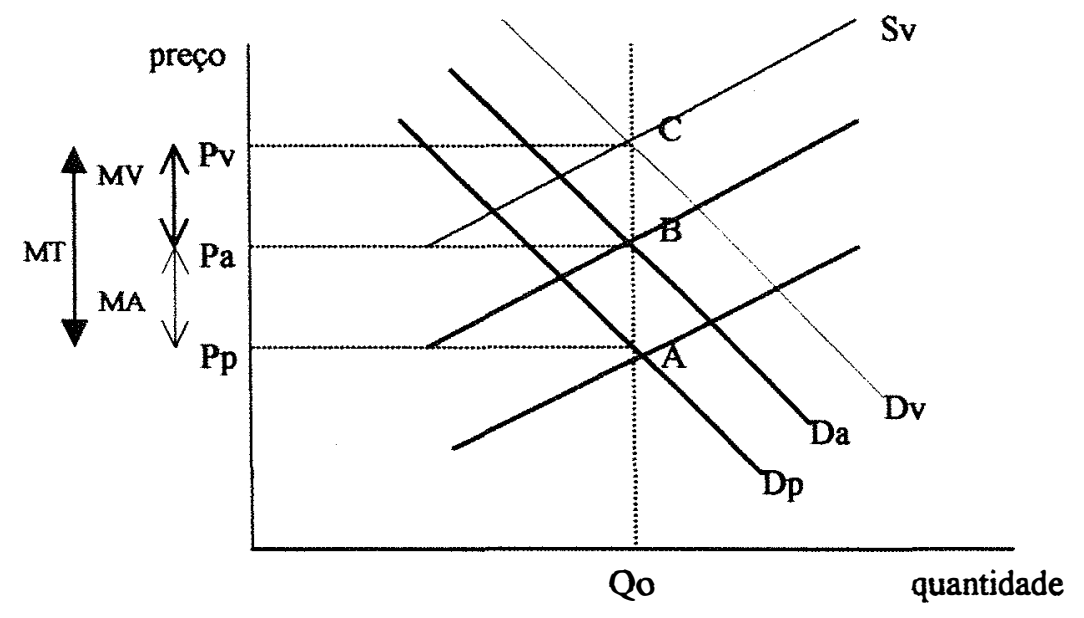

Figura 9 - Margens de comercialização e preços

É possivel determinar também a Margem Total Relativa (MT'), as Margens Absoluta e Relativa do varejista $(M v)$ e $\left(M v^{\prime}\right)$ e do atacadista $(M a)$ e $\left(M a^{\prime}\right)$, que podem ter seus preços mensurados pelos métodos sistemático e não-sistemático. Do ponto de vista analítico, é mais interessante utilizar o primeiro método sob as formas de margem absoluta fixa, margem percentual fixa ou combinação das duas.

Os fatores que mais afetam as margens, segundo Barros (1987) e Marques \& Aguiar (1993), são: 
a) Características do mercado: quanto mais competitivo for o mercado, menores devem ser as margens. Por outro lado, um mercado oligopolizado tende a trabalhar com margens mais elevadas; b) Características do produto: quanto mais processado e manuseado for o produto, maiores serão as margens; c) Mudanças tecnológicas ao longo do tempo de análise. Melhorias genéticas, de armazenamento e de transportes tendem a reduzir custos e margens.

Incluem-se, ainda, os fatores relacionados à NEI, tais como as características transacionais que também podem influenciar as margens. Quanto mais eficientemente ${ }^{15}$ forem executadas as transações dentro de determinado sistema, menores tendem a ser as margens. Outro ponto relevante diz respeito à assimetria de informações. Neste item, quem possuir maiores e melhores informações pode usá-las para aumentar suas margens. Estas se tornam uma importante interligação entre as duas teorias propostas neste estudo.

O estudo de margens de comercialização fornece subsídios para uma detalhada e realista análise econômica. Quando corretamente determinada, constitui-se em instrumento útil de análise da eficiência de todo o sistema, cujos resultados podem auxiliar órgãos públicos na formulação de políticas agrícolas e a iniciativa privada no seu planejamento estratégico.

O problema é que, na maioria das vezes, a metodologia utilizada é deficiente, levando a resultados discrepantes causados principalmente pela ausência de um sistema que permita comparação adequada entre o preço pago pelo consumidor final e o valor recebido pelo produtor rural pelo mesmo produto. Deste modo, a determinação dos fatores ponderais de equivalência que permitam a comparação entre os níveis do produtor e do consumidor é crucial para a credibilidade de um estudo sobre margens de comercialização. 
Para produtos primários, não sujeitos a transformações substanciais entre a fazenda e o consumidor final, como frutas e vegetais, existe maior facilidade de cálculo das margens setoriais. Produtos sujeitos a manipulação do seu estado natural, porém, são mais complexos de serem estudados. As cames encontram-se neste setor, pois são comparados animais vivos com carcaça e diferentes cortes no varejo. Para o suíno, a questão é ainda mais complicada se for levada em consideração a gama de produtos industrializados provenientes dessa matéria-prima. Portanto, mesmo sabendo que $70 \%$ do destino da came suína são a transformação em produtos industrializados, desconsiderou-se sua análise, devido à enorme complexidade de sua determinação. Utilizou-se, então, apenas o comparativo das cames in natura.

O mais importante, entretanto, é poder visualizar como as margens variam ao longo do tempo, desde que a metodologia empregada seja a mesma para toda a série histórica. Esta, porém, se muito extensa, pode causar distorções graves, uma vez que a tecnologia de produção é constantemente modificada, levando a um diferencial de composição de carcaça do animal no decorrer do período. Isto implica que o tipo de criação utilizado vinte anos atrás passou por uma grande mudança quanto a manejo, genética e nutrição para atender às exigências dos consumidores. Estes tendem a tornarse cada vez mais exigentes no que se refere a aparência e segurança alimentar (food safety).

Vários já foram os estudos no Brasil sobre determinação de margens de comercialização, sendo importante destacar o trabalho de Junqueira e Canto (1971), no qual foram determinadas as referidas margens para uma cesta de mercadorias na Cidade de São Paulo. Canto et al. (1986) fizeram outro estudo destacando os coeficientes para a determinação do preço equivalente-fazenda de diversos produtos, inclusive as cames aqui analisadas. Especificamente com carnes, há as dissertações de mestrado de Parré

\footnotetext{
${ }^{15}$ Entende-se por eficiência o que foi definido no subitem 4.1.1.
} 
(1995) e Bitencourt (1996), com a determinação das margens para bovinos e frangos respectivamente.

Até então, trabalhos desenvolvidos visando exclusivamente à carne suína no mercado brasileiro são deficientes. Em Canto et al. (1986), desmembrou-se a estrutura para uma correta utilização da metodologia de cálculos de margens, mas, nesta, foi efetuado um corte estático, não se podendo observar variações no decorrer do tempo. Spohr et al. (1996) tentaram determinar, de maneira sucinta, o exagero das margens sobre a carne suína, mas utilizaram preços de apenas um ano para determinados cortes e embutidos na região da Grande Porto Alegre. Nessa pesquisa, os autores não consideraram a participação dos produtores, analisando apenas as parcelas do atacado e varejo, comparando-as no caso do frango. Assim, não foram calculados o equivalentefazenda nem a ponderação da carcaça. Os principais valores encontrados foram 40,2\% de margem relativa do varejo para os principais cortes suínos in natura e 43,6\% para a média de onze produtos industrializados de origem suína. Para o frango, as cifras não ultrapassaram os $20 \%$.

Em nenhum dos trabalhos acima citados houve o intuito de comparação histórica das margens entre as carnes de maior consumo no Brasil, e nem de verificar se estas seriam semelhantes ou não. Diante deste quadro, propõe-se aqui fazer esta análise a fim de buscar subsídios que ajudem a provar se um agente da cadeia, seja ele produtor, atacadista ou varejista, está apropriando-se de maiores margens em detrimento de outro, e se há perda de competitividade no âmbito do sistema como um todo. 


\section{MATERIAL E MÉTODOS}

\subsection{Dados}

Para justificar a hipótese (a), referente a Custos de Transação, os dados foram obtidos via levantamento de fontes secundárias e entrevistas direcionadas com membros atuantes no setor. Foram feitas viagens e entrevistas in loco quando possível. Para Masten (1994, p. 9), a identificação de novas fontes de dados, a fim de melhorar as medidas das variáveis de custos de transação, é o principal desafio da pesquisa nesta área. Proxes são usados com frequência. Joskow (1987), por exemplo, explorou diferenças regionais a distâncias alternativas de transporte e características fisicas do carvão como proxy para determinar variáveis como especificidade dos ativos.

Dados para testar a hipótese (b) sobre margens de comercialização foram obtidos no Instituto de Economia Agrícola do Estado de São Paulo (IEA-SP). Especificamente, foram cifras de janeiro de 1989 a julho de 1996 para preços ao produtor de suínos, bovinos e frango em São Paulo, preços ao atacado (equivalente-carcaça) e preços médios das três carnes nos estabelecimentos varejistas da Cidade de São Paulo. Após tabulados, foram deflacionados pelo Índice Geral de Preços (IGP-DI) publicado pela Fundação Getúlio Vargas a preços de julho de 1996.

\subsection{Método}

\subsubsection{Metodologia de pesquisa para o enfoque da NEI}

$\mathrm{Na} \mathrm{NEI}$, dados focados somente em preço e quantidade não são suficientes para sua correta utilização. Para Masten (1994, p. 5), hipóteses de custos de transação em 
contraste requerem dados de forma organizacional assim como informações detalhadas sobre caracteristicas de transações com o nivel de incerteza associado às relações comerciais. Mesmo assim, dados como especificidade dos ativos não são facilmente quantificáveis. Joskow (1995, p. 126) corroborou alegando que o máximo que podemos esperar são informações mais qualitativas em variações na importância da especificidade dos ativos.

A metodologia proposta para a elaboração do enfoque relacionado à NEI é, como descreveu Jank (1996, p. 49-53), baseada na literatura, na análise quantitativa dos dados referentes às relações contratuais entre produtores e indústrias e em entrevistas focalizadas. Com base em Mattar (1993), optou-se pelo seguinte método de pesquisa:

a) Levantamento em fontes secundárias de dados como livros, revistas, artigos específicos, trabalhos acadêmicos entre outros; b) Levantamento de estatísticas publicadas em órgãos como IBGE, IEA, ITP, FAO, WTO e USDA; c) Levantamento de experiências em entrevistas diretas, buscando aprofundar o conhecimento sobre $\mathrm{O}$ assunto, com individuos que ocupam posições privilegiadas na estrutura das organizações, sejam elas de cunho privado ou govemamental. Para justificar, Mattar (1993, p. 87) afirma que o número de entrevistas não é definido, devendo ser realizadas tantas quantas forem necessárias para a compreensão do assunto, pois o importante é a escolha do entrevistado em se tratando de uma pesquisa qualitativa. Deste modo, o melhor teste formal da proposição da teoria dos custos de transação seria a utilização de dados acumulados de pesquisas de campo e entrevistas ${ }^{16}$. Diversos trabalhos empíricos foram desenvolvidos com este método. Monteverde \& Teece (1982), por exemplo, utilizaram este tipo de coleta de dados em seu trabalho sobre o setor automotivo. Eles trabalharam, como hipótese nula, o fato de que a especificidade dos ativos não era importante para explicar variações na integração vertical, e, como hipótese alternativa, que há integração vertical quando a especificidade for mais importante, sendo isto 
comprovada. Já Masten (1984) adotou o meio de entrevistas diretas com experts industriais para obtenção de dados utilizados como proxies em seu estudo aeroespacial.

As entrevistas devem ser elaboradas com perguntas definidas, abrindo possibilidade de respostas por parte dos entrevistados. A este tipo de questionamento, Mattar (1993, p. 175) denomina entrevista focalizada individual, pois busca profundidade e não amplitude; sua íntegra encontra-se no Apêndice 1. Trata-se, portanto, de uma pesquisa de campo em condições reais e atuais.

Após a coleta de dados e a finalização das entrevistas, aplicar-se-á o modelo anteriormente descrito a fim de poder identificar a forma organizacional alternativa mais adequada, dadas as condições locais.

\subsubsection{Metodologia utilizada na determinação das margens de comercialização}

Um dado bastante importante para o cálculo das margens é a determinação do valor equivalente-fazenda. O primeiro passo para obtê-lo é identificar a quantidade do produto que precisa ser adquirida na fazenda para efetuar a venda de uma unidade no varejo. Nas cames, como na maioria dos produtos agrícolas, a quantidade adquirida pelos produtores é maior que a vendida aos consumidores, pois parte do produto é desperdiçada nos canais de comercialização ou composta de subprodutos comercializáveis ou não.

Para os suínos, mesmo sabendo que a tendência de pagamento do produto pelos frigoríficos deverá ser feita pelo peso e pela qualidade da carcaça, utilizando a tipificação, optou-se pela unidade de compra ao produtor ainda pelo quilo vivo. Isto porque, no Estado de São Paulo, área de atuação da pesquisa, a utilização deste método

${ }^{16} \mathrm{O}$ Anexo $\mathrm{D}$ contém a lista dos estados e das principais entidades visitadas e entrevistadas. 
ainda prevalece. Deste modo, devem ser descontadas as perdas na comercialização, as quais associam-se principalmente à "barrigada", composta pelas vísceras abdominais e por restos alimentares, resultantes do abate. Alguns desses subprodutos têm utilidade, mas seu reduzido preço de mercado faz com que muitos abatedouros optem por terceirizar seu processamento, vendê-los ou simplesmente jogá-los fora. Por isso, decidiu-se, nos cálculos aqui elaborados, considerá-los como perdas, utilizando o coeficiente técnico publicado por Canto et al. (1986), ou seja, 1,228. Este foi conseguido com a divisão do peso do animal vivo pelo peso da carcaça fria resultante do evisceramento. Os autores consideram 94 quilos de peso vivo para uma carcaça de 76,55 quilos. O Anexo $\mathrm{C}$ discrimina toda a divisão dos cortes e seus respectivos pesos proporcionais. Como esclarecido anteriormente, sabe-se que este coeficiente encontra-se em constante mudança, devido ao desenvolvimento tecnológico e a melhorias constantes nas áreas de genética, nutrição e manejo que refletem na conformação da carcaça. $O$ ideal seria haver uma atualização desse valor pelo menos a cada cinco anos. Mas, como há grande carência de estudos fidedignos sobre o assunto, optou-se pela manutenção desse índice.

Para o frango, utilizou-se a mesma metodologia descrita para os suínos, sendo o coeficiente, encontrado por Canto et al. (1986), 1,365, significando que a carcaça dessa ave tem peso $36,5 \%$ inferior ao do animal vivo. No caso dos bovinos, o processo é diferenciado, pois a medida de negociação que ainda prevalece por parte dos frigoríficos é a arroba líquida. Esta pode ser determinada pela pesagem da carcaça após o abate ou pelo peso vivo do animal descontando $50 \%$ referentes às perdas e subprodutos, mais 12 horas de curral, período em que o animal permanece em jejum antes de ser pesado. Desta maneira, como os abatedouros aproveitam alguns subprodutos cujos valores não foram pagos ao produtor e que, segundo Parré (1996), somam aproximadamente $12 \%$ do total da carcaça. 
A diferença desse índice existe porque, nos exemplos anteriores do suíno e do frango, a comercialização é feita com peso vivo, portanto, já está incluído, no preço combinado, o valor de perdas vicerais e subprodutos. No caso dos bovinos, tradicionalmente, quando se negocia o animal vivo, consideram-se apenas os $50 \%$ de carcaça aproveitável. Isto significa que o pagamento pelo boi gordo se faz somente pelo valor líquido. Mas, inseridos nesse desconto, podem ser aproveitados $12 \%$ do valor não pago, com a comercialização de subprodutos como couro, sebo e fígado, o que não acontece com suínos e aves; chegou-se, portanto, ao coeficiente 0,88 ou à mera subtração de $12 \%$ da unidade.

Assim sendo, para a determinação do valor equivalente fazenda dos suínos e aves, basta multiplicar o preço pago ao produtor pelo índice da quantidade equivalente na fazenda, 1,227 e 1,365 respectivamente, e, em se tratando de bovinos, multiplicar por 0,88. Após a determinação dos índices de equivalência fazenda para as três cames, pode-se utilizar as fórmulas de cálculos das margens, adotando as seguintes expressões:

$$
\begin{aligned}
& M T=P V-P P \\
& M A=P A-P P \\
& M V=P V-P A \\
& M T^{\prime}=(P V-P P) / P V \\
& M A^{\prime}=(P A-P P) / P A \\
& M V^{\prime}=(P V-P A) / P V \text { onde }
\end{aligned}
$$

$\boldsymbol{M T}=$ Margem absoluta total como sendo os preços do varejo menos os valores recebidos pelos produtores na quantidade equivalente fazenda;

$\boldsymbol{M A}=$ Margem absoluta do atacado; $\boldsymbol{M} \boldsymbol{V}=$ Margem absoluta do varejo; 
$\boldsymbol{P P}=$ Preço ao produtor do equivalente fazenda, calculado multiplicando-se o preço pago ao produtor pelo coeficiente técnico obtido com o desmembramento da carcaça, descontados os subprodutos, como descrito acima;

$\boldsymbol{P} \boldsymbol{A}=$ Preço real no nível do atacado;

$\boldsymbol{P V}=$ Preço real no nível do varejo;

$M T^{\prime}=$ Margem total relativa (se multiplicada por cem, torna-se margem percentual);

$\boldsymbol{M} \boldsymbol{A}^{\prime}=$ Margem relativa do atacado;

$M V^{\prime}=$ Margem relativa do varejo. 


\section{ANÁLISE DOS RESULTADOS}

Este capítulo é dividido em duas partes principais. Em cada uma, serão analisados os resultados referentes às hipóteses sugeridas. Primeiramente, será focalizada a questão pertinente às relações contratuais entre produtores e indústrias. Posteriormente, aplicar-se-á o modelo, identificando as formas organizacionais atualmente utilizadas nas referidas localidades, sugerindo, em seguida, de acordo com os dados da pesquisa, as que minimizam os custos de transação, comparando-as com trabalhos desenvolvidos em outros países.

$\mathrm{Na}$ segunda parte, serão apresentados os resultados numéricos do estudo de margens de comercialização. As demonstrações gráficas comprovam o que se propôs testar na segunda hipótese.

\subsection{Referente à hipótese da Nova Economia Institucional}

Após a realização de viagens e entrevistas pessoais com experts em todas as áreas do sistema suinícola de diferentes regiões do território nacional, observou-se, dependendo da localização, a existência de diferentes estruturas de govemança. As formas organizacionais entre produtores e indústrias variaram entre mercado $(M)$, em parte das regiões Sul, Centro-Oeste e em toda a Região Sudeste, forma híbrida $(X)$ contratual rígida ou "quase-integração"17 na grande parte da Região Sul do país, e total integração vertical $(H)$, encontrada nas novas instalações do Mato Grosso. Destacou-se

17 O termo formas intermediárias contratuais rígidas ou quase integração foi formulado por Monteverde \& Teece (1982), identificado como a propriedade de uma firma sobre equipamentos ou insumos específicos operados por outra firma pertencente a segmentos que the são correlatos. 
cada uma delas separadamente e, posteriormente, buscou-se justificar o porquê da utilização de diferentes estruturas de governança em cada região.

a) Na Região Sudeste, especificamente em São Paulo e Minas Gerais, o que se observou foram produtores e indústrias utilizando a forma organizacional mais simples, isto é, o mercado $(M)$. Isto acontece devido principalmente à existência de um elevado número de abatedouros que concorrem entre si, não havendo nenhum de tamanho suficientemente grande para interferir no mercado. Observou-se que a maior parte dessas indústrias são de porte médio e cuja linha de abate não é específica para suínos.

Esses frigorificos, apesar de tentarem unir-se para se fortalecerem ainda mais em relação aos produtores, aumentando o poder de barganha, entram constantemente em concorrência acirrada. Os produtores, em número muito maior, o que prejudica o poder de negociação, tentam fazer uma "bolsa" para determinar um preço a ser praticado durante a semana vigente. Os frigorificos, mesmo que convidados, não participam, preferindo negociar pessoalmente a aquisição de suas matérias-primas. O cumprimento ou não do preço indicado pela "bolsa" é feito dependendo do comportamento momentâneo do mercado. Normalmente, o "preço-bolsa" somente é cumprido para com os produtores tradicionais de médio e grande porte, restando aos pequenos associaremse em cooperativas, venderem sua produção para intermediários ou ainda suprirem diretamente açougues na clandestinidade.

Seguindo uma tendência mundial, esses produtores tendem a desaparecer, em detrimento da expansão produtiva dos médios e grandes, devido a economias de escala e consequentes reduções nos custos de produção. A fim de legitimar uma bolsa de comercialização fisica, criou-se, na França, um mecanismo bem estruturado do tipo leilão eletrônico. Realizado duas vezes por semana, esse leilão, denominado Marché au Cadran, comercializa aproximadamente $20 \%$ de toda a produção de suinos daquele país, além de servir de referência para outros mercados. Nele, compradores adquirem os lotes 
através de um placar de contagem regressiva quanto ao preço, bastante semelhante aos leilões de flores do Veilling da Cooperativa Holambra no Estado de São Paulo.

Observou-se, no entanto, um descontentamento por parte de produtores e abatedouros a respeito da forma de comercialização vigente no Brasil. Isto acontece porque os agentes envolvidos são muito vulneráveis às oscilações mercadológicas que prejudicam planejamentos futuros e repasses de preços. Há períodos de ganhos relativamente elevados, intercalados por períodos de crise para ambas as partes ${ }^{18}$. Esses ciclos de rentabilidade fazem um autoprocesso seletivo, isto é, os menos eficientes acabam sendo forçados a deixar a atividade nos períodos de lucratividade negativa. Para minimizar os problemas relacionados à comercialização, produtores buscam fazer "programações" com determinados frigorificos. Esta forma nada mais é do que uma relação contratual, mesmo que apenas verbal, entre produtor e indústria, garantindo, de cerna forma, a colocação dos cevados programados no mercado a um preço preestabelecido. A maior formalização desse tipo de contrato pode ser uma boa opção de comercialização. Nos Estados Unidos, por exemplo, existe uma espécie de banda de preços window em que, através de um contrato formal de longo prazo, suinocultores e frigoríficos determinam um preço máximo e um preço mínimo entre os quais a mesma flutua. Caso o preço de mercado caia abaixo do limite mínimo, os frigoríficos comprometem-se a pagar esse limite. Quando o preço exceder os patamares superiores, os produtores recebem apenas o máximo acertado previamente.

b) No Sul, a história é um pouco mais complexa. A forma organizacional tornase bem menos independente, com exceção do sul de Santa Catarina e de algumas regiões isoladas do Rio Grande do Sul, onde também há produtores independentes. O Paraná já apresenta transitoriedade quanto ao regime organizacional. $O$ sistema cooperativista ou a forma contratual híbrida são o que prevalece, apesar de ambos adotarem comportamentos bastante semelhantes. A estrutura de governança híbrida $(X)$ 
é marcada por extrema rigidez no que diz respeito aos contratos de parceria produtorindústria.

c) O caso extremo de total integração vertical $(H)$ é encontrado no Mato Grosso. Lá, a suinocultura, apesar de incipiente no estado, já se inicia com grandes granjas e utilizando as mais modernas técnicas de manejo, nutrição e genética. Sempre com a intenção de agregação de valor, os produtores integraram-se transformando grãos em proteina animal inicialmente e, posteriormente, agindo também na área de abate e transformação.

Em Rondonópolis, o Grupo Agra, composto por uma associação de grandes produtores, foi formado quando estes se reuniram para fazer um frigorifico. $\mathrm{O}$ exemplo foi seguido por uma união de sete cooperativas do centro-norte do estado, formando a Intercoop, também com o intuito de abater sua produção. Novos investimentos em suinocultura são anunciados com frequencia nessa região, devido principalmente às suas vantagens comparativas.

No Distrito Federal, há também um exemplo semelhante de suinocultores que se integraram para frente, partindo para a atuação na área de abate.

A idéia é sempre a mesma: transportar produtos de maior valor agregado (cortes desossados e embutidos) em vez de animais vivos ou até mesmo grãos. Mesmo que o frete de produtos beneficiados seja mais caro, frigorificado por exemplo, na maioria das vezes, compensa pelo valor monetário transportado por tonelada. É por isso que a suinocultura nacional tende a redirecionar-se para as regiões produtoras de grãos. Em uma nova localização, a estrutura organizacional tende a ser outra, com maior uso de tecnologia e de maiores dimensões.

${ }^{18}$ Ver Hackenhaar (1995) 


\subsubsection{Aplicação do modelo proposto}

De acordo com o modelo de ECT, em sua forma reduzida, proposto por Riordan \& Williamson (1985) e descrito no Capítulo 5, foi possível o teste empírico das proposições questionadas. Transações foram dimensionalizadas em atributos observáveis, possibilitando a inferência dos custos associados a cada transação. Esta dimensionalização foi baseada na análise comparativa das diferentes especificidades nas regiões brasileiras. Foi observado que, mesmo o ativo suíno sendo o mesmo, há uma grande diversidade quanto aos vários tipos de especificidade para o produto. Isto leva à utilização de estruturas de governança diversas, de acordo com as condições locais, pois trata-se de um pais de dimensões continentais e cujo perfil tanto produtivo quanto industrial difere enormemente.

O perfil do produtor e a concentração das agroindústrias processadoras nos estados do sul levam os mesmos à obtenção de certas especificidades que diferem das do restante do país, fazendo com que o mesmo produto seja mais específico em uma região do que em outras, justificando a adoção de diferentes formas organizacionais. Uma comparação foi feita com os sistemas utilizados nos Estados Unidos, vindo a corroborar a consistência do modelo, justificando sua utilização em qualquer pais de economia aberta e concorrencial.

A hipótese levantada, por sua vez, afirma que nem sempre a estrutura de governança adotada é a que "melhor se adequa", dadas as condições locais, ou está situada na posição minimizadora de custos de transação.

No sul, por exemplo, destaca-se a especificidade locacional ao verificar se a concentração de indústrias processadoras de suínos, principalmente no oeste catarinense. Deste modo, quanto mais próximo a uma importante planta industrial compradora, mais específico se toma o produto. Isto acontece porque, como a indústria 
praticamente monopsoniza a compra de suínos em sua região de domínio, o suinocultor passa a não ter opção de venda, a não ser transportando seu produto para localidades afastadas, incorrendo em elevados custos. Apesar de existirem várias (6) grandes agroindústrias concentradas nessa localidade, elas agem semelhantemente em relação aos parceiros contratados, não concorrendo entre si e até mesmo combinando previamente a divisão desses. Assim, forma-se um oligopsônio, mas que age como se fosse uma só empresa adquirente da matéria-prima suíno.

Já em outros estados, o mesmo não acontece, pois não há concentração de abatedores nem plantas industriais de grande porte que dominam determinada região a ponto de influenciar o mercado. A especificidade de local é, então, menor. Portanto, a estrutura de mercado é essencial na determinação da especificidade e, consequentemente, na escolha da forma organizacional.

Nos Estados Unidos, o SAG suinícola também está passando por profundas modificações. A concentração mostra-se clara. Segundo Barkema \& Cook (1993, p. 50), durante as últimas duas décadas, o número de suinocultores caiu de 900.000 para 250.000 , enquanto a produção apresentou elevação. Com empreendimentos cada vez maiores, crescem também os riscos a eles associados. Surge, então, o crescente interesse na formação de contratos entre produtores e indústrias. De acordo com Rhodes, citado por Barkema \& Cook (1993, p. 50), mais de 16\% dos suínos produzidos em 1992 foram comercializados sob a forma de algum contrato e esta cifra vem crescendo a elevadas taxas. O principal incentivo a essa medida está na redução de riscos. Pesquisa feita por Kliebenstein \& Lawrence (1995, p. 1215) mostra que $44 \%$ dos produtores da região central leste dos Estados Unidos e $60 \%$ de Iowa apontam o fator risco como principal indutor dos contratos. Estes, como no Brasil, variam de acordo com a região e, principalmente, quanto à concentração de abatedouros. 
Dos 34 maiores produtores norte-americanos, todos com mais de 10.000 matrizes, nove são integrados verticalmente, possuindo participação acionária em frigoríficos, e doze outros têm algum tipo de arranjo contratual. Uma justificativa a esta iniciativa, corroborando a hipótese de especificidade locacional, é que dez dessas 34 megagranjas situam-se na Carolina do Norte, onde há pouca opção de abatedouros. O mesmo não acontece no Estado de Iowa. Com vários frigoríficos abatendo, há concorrência para adquirir suínos, induzindo a atuação pura do mercado. Portanto, contratando, os produtores têm assegurado um mercado para escoamento de sua produção e um preço com bases predeterminadas. Os métodos mais comuns de determinação de preços são através de window prices, nos quais estes variam apenas dentro de uma banda com limites mínimos e máximos; o menos usado, cost plus combina o pagamento de uma porcentagem a título de lucro sobre uma planilha de custos de produção. Há, também, contratos semelhantes aos utilizados pelas agroindústrias do sul do Brasil, denominados de "quase-integração".

Outro ponto relevante com relação aos frigoríficos é quanto à modernização tecnológica das plantas industriais. As grandes indústrias processadoras precisam que os animais para abate sigam determinados conceitos de homogeneização, uma vez que o abate é quase que essencialmente executado para produzir matéria-prima para processamento. As máquinas e os equipamentos são regulados para trabalhar com determinado padrão e tamanho de insumos, podendo perder em produtividade caso não sejam seguidas as indicações. Assim, o mercado spot passa a ser incapaz de atender com eficiência o suprimento das escalas de abate que precisam trabalhar com suas linhas otimizadas. Por outro lado, frigoríficos de outros estados fora da Região Sul trabalham praticamente com carcaça e carne desossada in natura, industrializando basicamente os subprodutos. Suas máquinas são menos especializadas e a padronização é menos exigente. Deste modo, pode-se concluir que, quando se refere a especificidade física, o mesmo suíno é considerado mais específico onde a tecnologia de abate é mais especializada. 
Nos Estados Unidos, segundo a NPPC, grandes empresas produtoras como Tyson Foods, Premium Standard Farms, Smithfield Foods, Clougherty Packing Company e Farmland Industries possuem seus próprios frigorificos. Outras como Murphy Family Farms, Carroll's Foods e Prestage Farms têm participação acionária no frigorífico Smithfied. O abatedouro Monfort do grupo ConAgra adquire aproximadamente $20 \%$ de sua matéria-prima através de contratos de longo prazo do tipo window e acredita que, dentro de cinco anos, alcançará mais de $70 \%$. Ele está sendo seguido pelo Excel, da Cargill. Já o IBP prefere não se envolver com contratos de divisão de riscos. Constatase, assim, que nem todas as empresas compartilham da mesma opinião.

A integração vertical pode minimizar ainda mais os riscos de regularidade, homogeneização e preço, mas apresenta custos administrativos extremamente elevados. Mais uma vez, semelhantemente ao Brasil, nos Estados Unidos, essa estrutura é mais difundida onde há carência de suprimento de suínos para abate. Isto só vem comprovar que a especificidade locacional pode levar desde a estruturas de governança de mercado, em regiões onde há pulverização de produtores e indústrias, até a de integração vertical, em lugares onde a presença dos processadores é tímida.

Não bastando as duas especificidades já descritas para justificar a utilização de determinadas estruturas de governança, foram ainda observadas outras duas para 0 ativo suíno, que não podem ser desconsideradas: a especificidade dedicada e a temporal.

A especificidade dedicada acontece quando o reemprego do ativo implica perda do valor gerado. Azevedo (1996, p. 156) destacou esta especificidade na questão referente aos citros no Estado de São Paulo, alegando que uma realocação da fruta cujo destino eram a fabricação e a exportação de Suco de Laranja Concentrado e Congelado (SLCC) para o comércio de fruta de mesa, caso houvesse algum rompimento contratual 
entre produtores e indústria, traria excesso de oferta e causaria, consequentemente, uma inevitável redução nos preços.

No caso específico dos suínos, fica transparente que, na região de concentração agroindustrial, onde $90 \%$ do abate transformam-se em matéria-prima para industrialização, o ativo é dedicado sob a mesma justificativa utilizada para o caso citado dos citros. Isto é, em se tratando de ruptura contratual, o suíno que seria abatido para industrialização deveria ser transferido para venda in natura, superabastecendo o mercado e, obviamente, derrubando os preços. O mesmo não se confirma em outras regiões fora dos estados sulistas, pois, como o suíno já tem como destino principal a venda na forma fresca, o risco de qualquer eventualidade é menor, já que existe sempre a alternativa de abater a própria produção, vendendo-a diretamente no mercado.

Pode-se afirmar que, quanto mais dedicado é o ativo, mais específico este se toma, elevando os custos de uma ação oportunista, o que provocaria um direcionamento à forma organizacional hierárquica.

Azevedo (1997, p. 101) lembra que especificidade é uma referência à magnitude do retorno de um ativo. No caso da especificidade temporal, esse retorno depende da ocorrência da transação, porque a busca de outros parceiros, pela sua demora, pode reduzir ou eliminar os ganhos derivados da troca.

O suíno tecnificado possui uma curva de crescimento e conversão alimentar que varia com a idade. Após certo tempo, esse animal perde em produtividade, piorando esses índices. Por isso, existe um período mais propício para a venda do animal ao abate, que varia de 140 a 160 dias, com este alcançando pesos que variam entre 90 e 115 quilos, dependendo da tecnologia de criação adotada. Caso o produtor não encontre demandantes no período ideal de venda, há certamente algum tipo de perda. Sendo 
assim, pode-se considerar esse animal, um produto com alta especificidade temporal, seja ele proveniente de qualquer localidade.

A partir de todas essas diferenças de especificidades do ativo suíno, chegou-se à conclusão de que, no Brasil, existem claramente os três tipos de estrutura de governança bem definidos e uma região ainda indefinida, como pode ser visto na Figura 10. O problema é que, aparentemente, com alguns ajustes a serem feitos, esses tipos poderiam vir a tornar o sistema mais eficiente, sendo este o objetivo deste trabalho. 


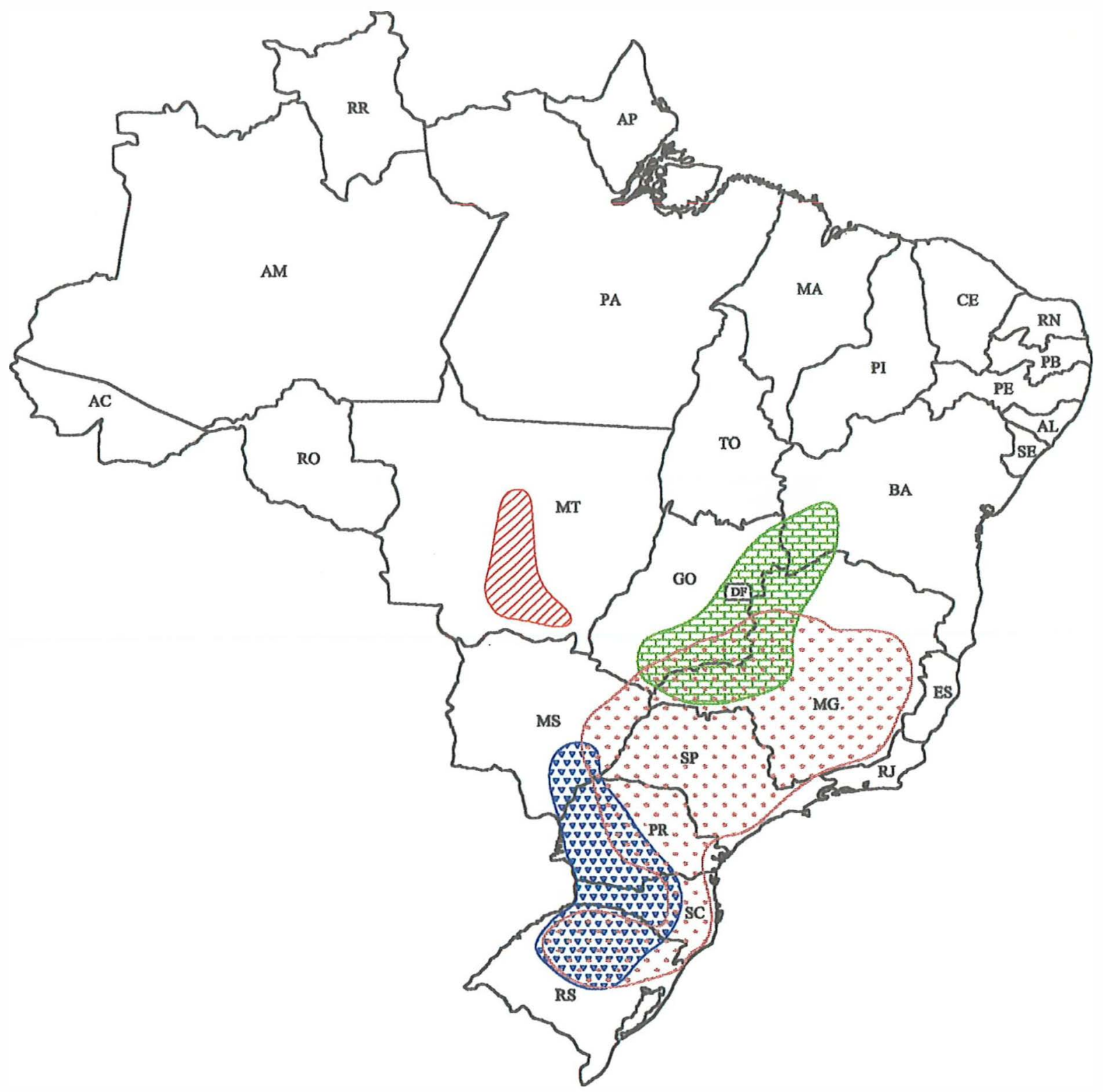

\begin{tabular}{|c|c|c|c|}
\hline $\begin{array}{c}\text { Estrutura de governança } \\
\text { observada no Brasil }\end{array}$ & $\begin{array}{l}\text { Tamanho dos } \\
\text { produtores }\end{array}$ & $\begin{array}{l}\text { Exemplo de } \\
\text { empresas }\end{array}$ & $\begin{array}{l}\text { Tipos de } \\
\text { produtos }\end{array}$ \\
\hline $\begin{array}{l}\text { Híbrido com grande rigidez } \\
\text { ou quase-integração }\end{array}$ & Pequenos (< 150 matrizes) & $\begin{array}{l}\text { Sadia, Perdigão, Ceval, } \\
\text { Aurora, Seara }\end{array}$ & $\begin{array}{l}\text { Basicamente } \\
\text { industrializados }\end{array}$ \\
\hline $\begin{array}{l}\text { Híbrido de menor rigidez (via } \\
\text { contratual) ou ainda indefinido }\end{array}$ & $\begin{array}{l}\text { Médios (de } 150 \text { a } 500 \text { matrizes) } \\
\text { e grandes ( }>500 \text { matrizes) }\end{array}$ & $\begin{array}{l}\text { Perdigão - GO } \\
\text { Rezende - MG }\end{array}$ & $\begin{array}{l}\text { Industrializados } \\
\text { e cortes }\end{array}$ \\
\hline Integração Vertical & $\begin{array}{l}\text { Médios (de } 150 \text { a } 500 \text { matrizes) } \\
\text { e grandes ( }>500 \text { matrizes) }\end{array}$ & $\begin{array}{l}\text { Agra - MT } \\
\text { Intercoop - MT }\end{array}$ & $\begin{array}{l}\text { Carcaça, cortes } \\
\text { e industrializados }\end{array}$ \\
\hline Via Mercado & Médios (de 150 a 500 matrizes) & $\begin{array}{l}\text { São João, Frigobet - MG } \\
\text { Angeleli - SP } \\
\text { Frigma - PR }\end{array}$ & $\begin{array}{l}\text { Carcaça e cortes } \\
\text { in nahurg }\end{array}$ \\
\hline
\end{tabular}

Fonte: Elaboração do autor

Figura 10 - Estruturas de governança observadas no Brasil 
- Recentemente, foi detectado o mercado como o arranjo institucional adotado no sudeste, mas com uma pressão para que haja maior formalização na comercialização, com a finalidade principal de reduzir riscos. Isto prova que, mesmo em regiões de produção tradicionalmente independente, o ativo suíno não deixa de ter certa especificidade. Assim, pode-se esperar o surgimento de contratos de longo prazo pouco rígidos de fornecimento, constando garantia de preço, qualidade, homogeneidade e constância, oferecendo ganho de eficiência. A baixa rigidez é desejável, pois esse tipo de produtor, até então já acostumado com a concorrência do mercado, normalmente possui bons índices técnicos e econômicos de produção.

- Um caso contrário ao primeiro item dá-se com a quase-integração do sul do país. Observou-se que, apesar do grande controle das agroindústrias sobre seus "parceiros", existe um custo muito elevado na execução dessa tarefa, como, por exemplo, na manutenção de um corpo técnico para dar suporte às centenas de pequenos produtores $\mathrm{e}$ também no transporte de cevados terminados das granjas aos abatedouros. Por outro lado, produtores gostariam de ter mais autonomia produtiva e, principalmente, de participar na formação de preços. Portanto, seria desejável e possivelmente mais eficiente se a atual forma contratual híbrida de grande rigidez perdesse um pouco desse controle. Prova disso foi observado nas viagens in loco, ficando evidente que as empresas que se instalaram (ou estão em processo de implantação) nas regiões fora do sul estão tendo dificuldade de aplicar o sistema quase-integracionista. A Rezende Alimentos, instalada em Uberlândia/MG, pretende obter, através desse sistema de quaseintegração, o suficiente para abastecer seu imponente frigorífico em $80 \%$ de sua capacidade de abate. Mas, devido aos já citados entraves a esse tipo de relação contratual, está tendo de rever sua posição. Outro exemplo claro é o da Perdigão, que pretende ampliar sua produção na região de Rio Verde/GO. Esta empresa, já praticante com sucesso da utilização da forma contratual rígida de relação com seus parceiros em Santa Catarina, vem tentando implantar sistema semelhante em Goiás. O mesmo problema identificado com a Rezende existe nessa região: o perfil dos produtores locais, 
normalmente grandes médios e grandes agricultores, não indica a tendência de se submeterem a um sistema contratual rígido. A viabilidade para essas empresas estaria em rever esse processo, tornando os contratos menos rígidos e dando maior autonomia aos produtores. Mas, a princípio, há uma aversão a esta idéia, que deverá ser revista inevitavelmente.

- O único arranjo institucional no Brasil que, aparentemente, está de acordo com a razão especificidade eficiente é a integração vertical do Mato Grosso. Isto se deve principalmente à ausência de alternativa de venda do ativo suíno, a não ser com grande perda de valor, significando a indesejável redução de eficiência. Isto é o que acontecia até a primeira metade de 1997. Com a ausência de abatedouros na região, os suínos eram enviados vivos até os grandes centros consumidores do sudeste, o que acarretava grande perda. Segundo um técnico da Intercoop, era calculado um custo adicional de $11 \%$ entre quebra e mortalidade em uma carga de cevados proveniente de Nova Mutum/MT até Belo Horizonte/MG. Atualmente, com a implantação de frigoríficos naquele estado, o envio se dá sob a forma de carcaça e cortes, apresentando um grande avanço em direção à eficiência sistêmica.

A Figura 11 demonstra graficamente como as estruturas de governança se situam diante das especificidades dos ativos observadas. Já a Figura 12 indica o direcionamento que as curvas deveriam tomar a fim de se ajustarem eficientemente diante da atual conjuntura do SAG suinícola nacional. 


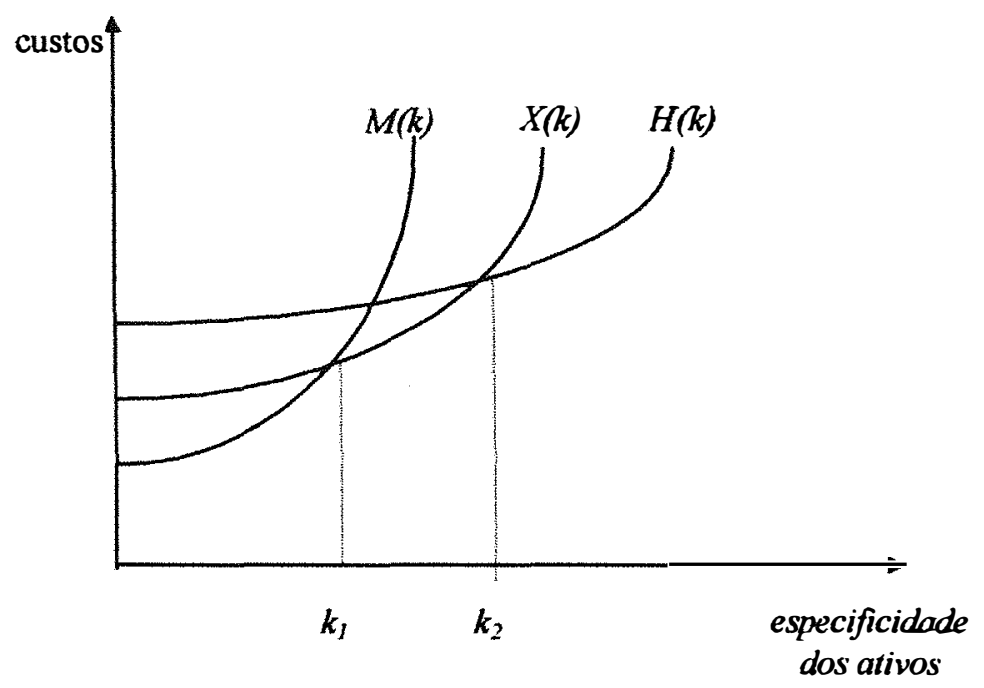

Figura 11 - Especificidade dos ativos e estruturas de governança

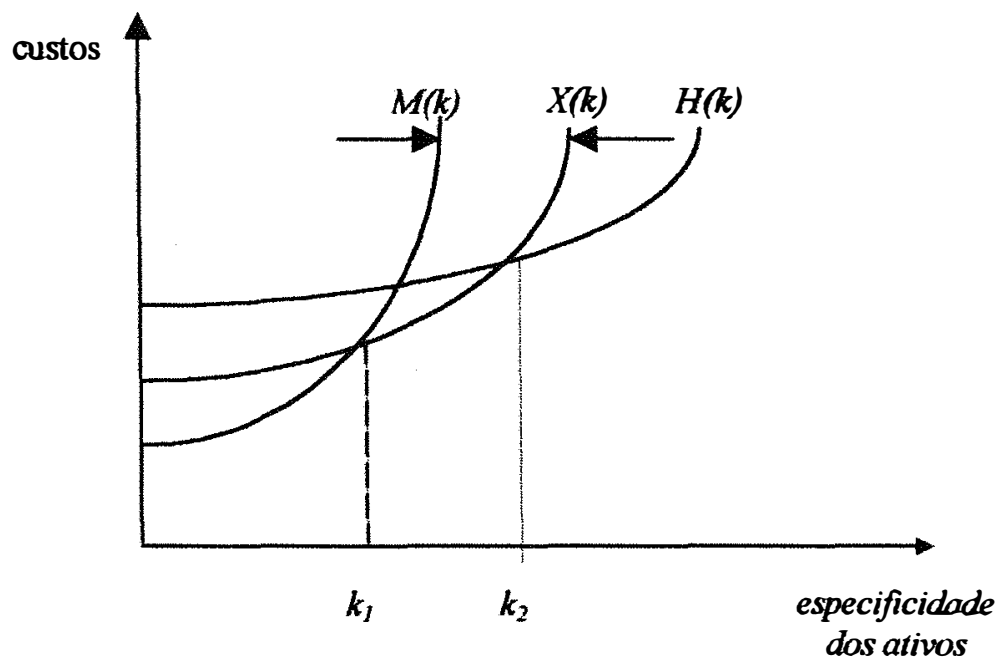

Figura 12 - Especificidade dos ativos e estruturas de governança com a indicação da direção dos ajustes sugeridos

Observou-se que o suíno produzido atualmente é um ativo que apresenta certa especificidade em quaisquer circunstâncias, mesmo sendo mais elevada em alguma região do que em outras. Deste modo, a forma organizacional via mercado pode perder importância nas regiões em que prevalece (como no sudeste), dando lugar a arranjos 
contratuais pouco rígidos entre produtores e indústrias. Esta característica foi detectada quando se observou o cada vez mais difícil ato de comercialização do suíno vivo.

Com a carne suína possuindo demanda inconstante durante o ano, em períodos de boa procura, os frigoríficos são obrigados a pagar um elevado preço pela matériaprima; porém, durante períodos de fraca demanda, o preço do produto não chega a ultrapassar os custos de produção. Estas oscilações, frequentes em locais onde produtores agem independentemente e adotam o mercado como estrutura de govemança, são prejudiciais tanto para produtores quanto para indústrias. Diante desta conclusão, a curva $M(k)$ deslocar-se-ia para a direita, em direção à forma híbrida (curva $X(k)$ ), como demonstrado na Figura 12.

Com relação à "quase-integração" das indústrias sulistas, representada pela curva $X(k)$, foi observado que os contratos deveriam se tomar menos rígidos, levando a um deslocamento dessa curva para a esquerda. Esta menor rigidez se dar-se-ia porque os suinocultores inseridos nessa estrutura estariam interessados em deter maior autonomia de seu negócio, enquanto que, pelo lado da indústria, a exigência na redução de custos poderia significar retração no monitoramento dos inúmeros parceiros e desvinculação de certos serviços como transporte. Já para facilitar esse controle, existe uma política, em implantação, de redução desses parceiros com a contrapartida na elevação do número de matrizes.

Acredita-se que, assim, a estrutura sistêmica poderia se tomar mais eficiente e competitiva.

\subsection{Referente à hipótese de Margens de Comercialização}

É importante lembrar que este trabalho busca estudar a competitividade sistêmica. Por isso, se um setor se capitaliza mais que outro, prejudicando este de 
alguma maneira, há nítida redução de eficiência no âmbito da cadeia, levando à consequente perda de competitividade. Foi exatamente isto que se observou no referente estudo.

O conceito de margem de comercialização não pode ser confundido com lucratividade, embora esteja a ela associado. Além do lucro, inclui os demais custos relacionados a processamento, embalagem, mão-de-obra etc.. Sendo de extrema dificuldade o cálculo desses custos, adotou-se a medida de comparação entre as carnes como referência, pressupondo serem semelhantes os custos de abate.

Inicialmente, com relação ao varejo, observou-se um declínio dos preços nas três carnes nos últimos sete anos, que pode ser visto na Figura 13. Mas, levando em consideração esses preços relativos, apresentados na figura seguinte, fica claro que o preço do frango caiu mais do que o de seus concorrentes. Quando analisados os preços da carne suína sobre a bovina, observa-se certa estabilidade. A pior relação surgiu quando foram comparados os preços finais da carne suína com os do frango, demonstrando claramente uma perda de competitividade da primeira no decorrer do tempo.

A partir desta primeira análise, tentou-se buscar justificativa para tal fato através do cálculo das margens de comercialização. A Figura 16 foi elaborada para demonstrar a diferença entre o preço do varejo e o valor equivalente fazenda de cada uma das carnes, isto é, a margem total de comercialização. Neste, foi detectada sempre a superioridade percentual da margem referente à carne suína.

No entanto, quando analisados os dados referentes às margens varejistas, plotados na Figura 15, passa a ser nítida a discrepância da carne suína frente a suas concorrentes. Enquanto a margem varejista do frango sempre se situou nos patamares inferiores, tendo uma média de apenas $23,6 \%$, a da carne suína foi, com pequenas 
exceções, a que apresentou os mais elevados valores. Sua média ficou em 50,67\%, representando mais que o dobro da anterior. O maior entrave, no entanto, é que, no decorrer do tempo, essa margem varejista do suíno tem aumentado. Os dados cedidos pelo IEA são referentes às médias de supermercados e açougues; sabe-se, porém, que as carnes ainda têm preços mais elevados nos primeiros. Como há tendência de aumento das vendas nos super e hipermercados, em detrimento dos açougues, pode ser esta uma justificativa do aumento recente das margens varejistas das três carnes. Entretanto, acredita-se que os super e hipermercadistas irão rever brevemente sua política de margem nas carnes, assim que ampliarem seu giro de vendas desses produtos.

Tabela 4: Médias das margens de comercialização em porcentagem das carnes no Brasil entre janeiro de 1989 e julho de 1996 e da carne suína nos EUA entre 1970 e 1995

\begin{tabular}{|l|c|c|c|c|}
\hline \multicolumn{1}{|c|}{ Médias } & $\begin{array}{c}\text { Suíno in natura } \\
\text { no Brasil }\end{array}$ & $\begin{array}{c}\text { Suíno in natura } \\
\text { nos EUA } \\
\text { entre 1970 e 1995 }\end{array}$ & Bovino & Frango \\
\hline Margem do atacado (frigorífico) & 12,21 & 15,33 & 15,57 & 28,27 \\
Margem do varejo & 50,67 & 27,77 & 36,56 & 23,60 \\
Margem total & 62,88 & 43,10 & 52,13 & 51,87 \\
\hline
\end{tabular}

Fonte: Elaboração do autor

Dados: Para o Brasil, dados fornecidos pelo IEA e deflacionados pelo IGP-DI.

Nos Estados Unidos, a situação encontrada foi um pouco diferente em alguns pontos, mas extremamente semelhante na maioria deles. A margem total de comercialização do suíno teve queda gradual até meados dos anos 80 , a partir de quando se manteve estabilizada. A margem do atacado cedeu espaço à varejista, como no Brasil. A justificativa encontrada foi que os custos de abate foram reduzidos com a modernização tecnológica dos frigoríficos, enquanto os varejistas estão tendo de investir cada vez mais em embalagens e marketing.

Em um trabalho específico para a carne suína desenvolvido por Schroeder \& Mintert (1996a) para a NPPC, associação nacional dos produtores de suínos dos Estados 
Unidos, foram analisadas as margens medidas em centavos de dólar por libra-peso para o período compreendido entre 1970 e 1995. Os resultados médios encontrados foram 31,4 centavos por libra de margem do atacado e 57 no varejo. Isto significa que, com o preço médio do quilo do suíno naquele país a US\$ 4.50, a margem total ficaria em $43,10 \%$, dividida entre a margem do atacado, com $15,33 \%$, e a do varejo, com $27,77 \%$. A participação do produtor foi reduzida de $59 \%$ para $34 \%$ no mesmo período, enquanto houve aumento significativo da margem no varejo. No mercado brasileiro, situação semelhante foi encontrada. Os números variaram de $23,2 \%$ em janeiro de 1990 a 48,8\% em abril de 1989. Todos os valores dos cálculos das margens das carnes nacionais encontram-se no Apêndice 3.

Outro trabalho desenvolvido pelos mesmos professores Schroeder \& Mintert (1996b) foi centralizado na causalidade dos preços da carne suína. Observou-se que variações semanais nos preços do atacado e do varejo respondem mais rapidamente à elevação do preço do suíno vivo do que à queda. Variações nos preços semanais dos atacadistas e varejistas são muito pouco refletidas para trás nos preços do suíno vivo, mas a longo prazo, existe clara tendência de acompanhamento.

A afirmação de que as margens de comercialização geralmente aumentam com a elevação da renda, destacada no trabalho de Briz \& de Filipe (1997), em que foram estudados os gastos com alimentos nos Estados Unidos entre 1968 e 1992, pode ser aqui correspondida na situação específica das cames no Brasil. Analisando as Figuras 15 e 16, observa-se que, após a implantação do Plano Real em julho de 1994, quando houve inegável aumento da renda populacional com o fim do imposto inflacionário, as margens totais de comercialização das três carnes cresceram. 


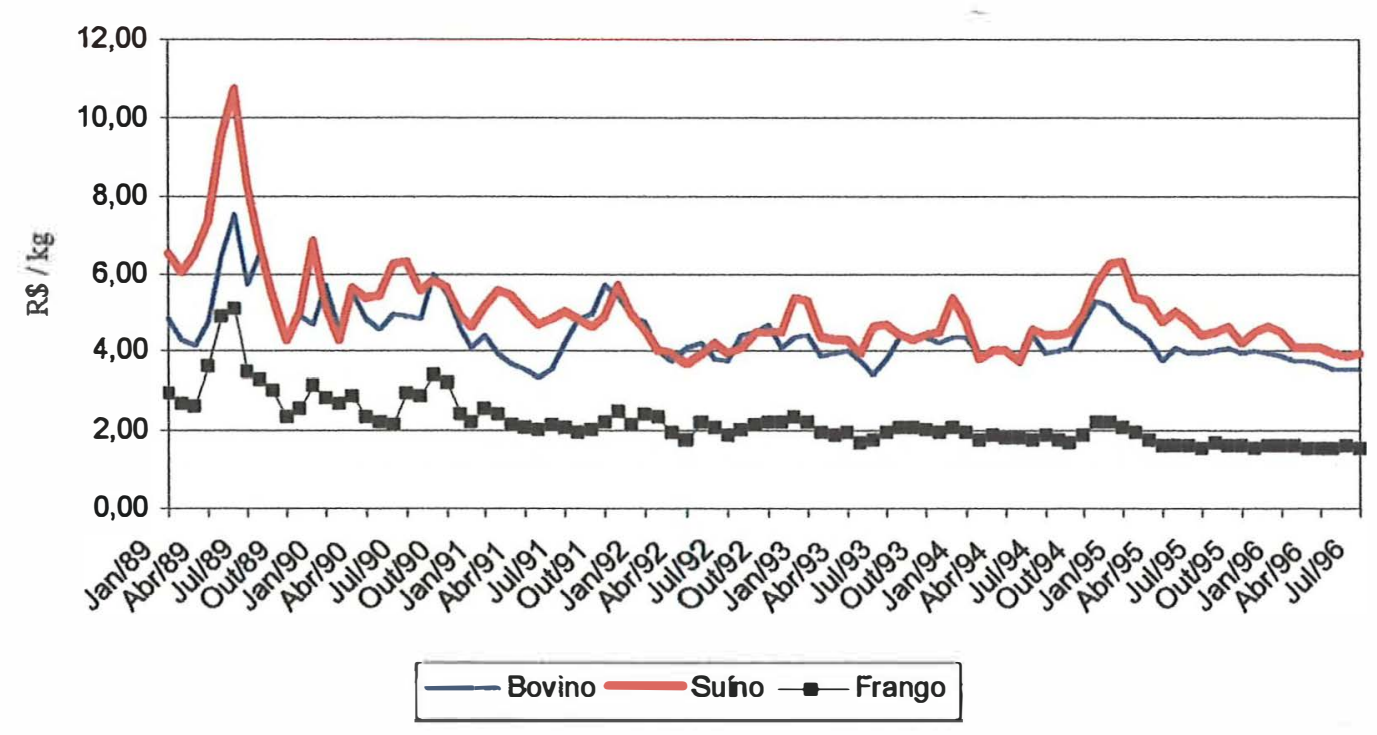

Fonte: Elaboração do autor com dados do IEA

Figura 13 - Preços médios dos cortes das carnes no varejo na Cidade de São Paulo

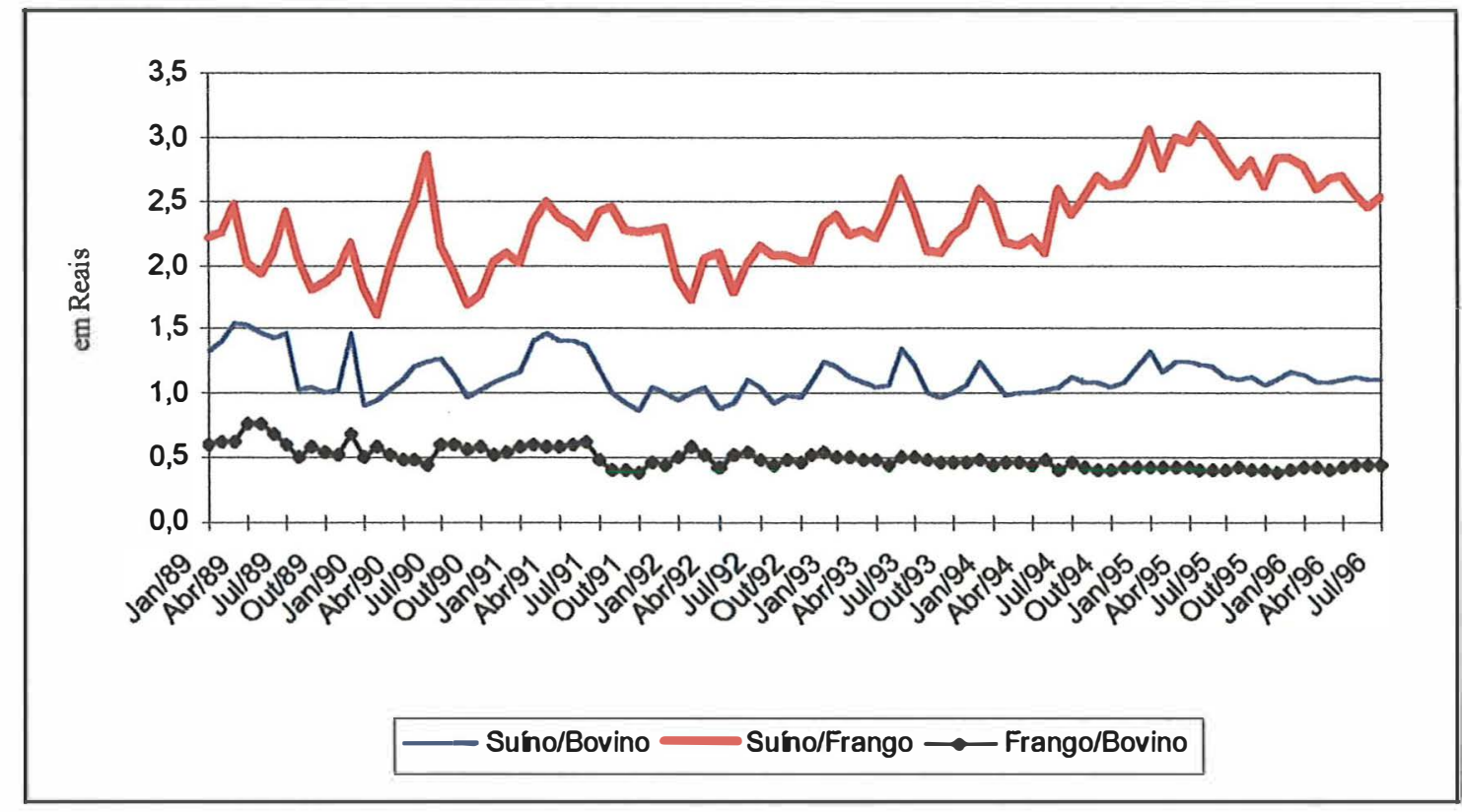

Fonte: Elaboração do autor com dados do IEA

Figura 14 - Relação de troca dos cortes das carnes no varejo na Cidade de São Paulo 


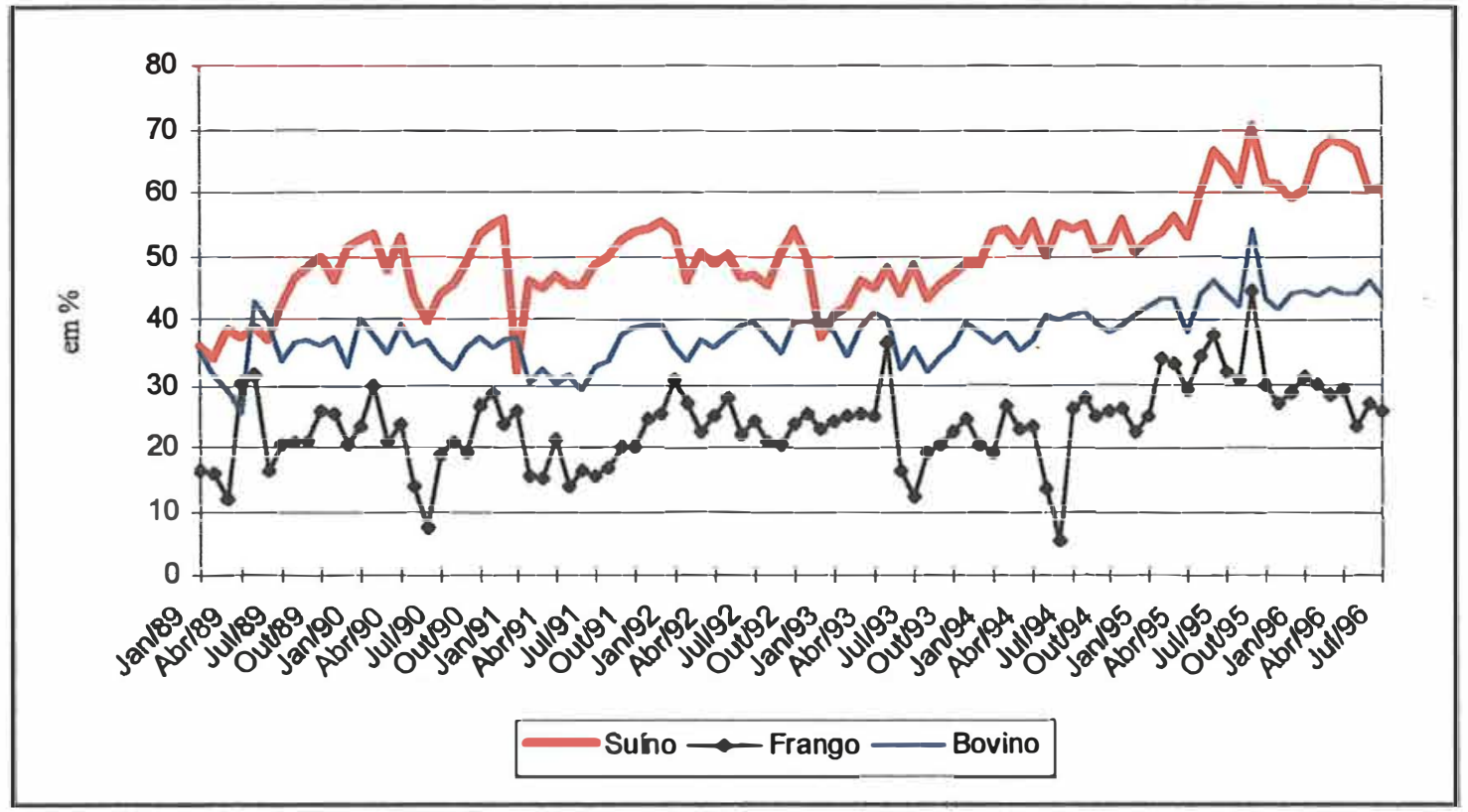

Fonte: Elaboração do autor com dados do IEA

Figura 15 - Margens de comercialização do varejo para as carnes em porcentagem

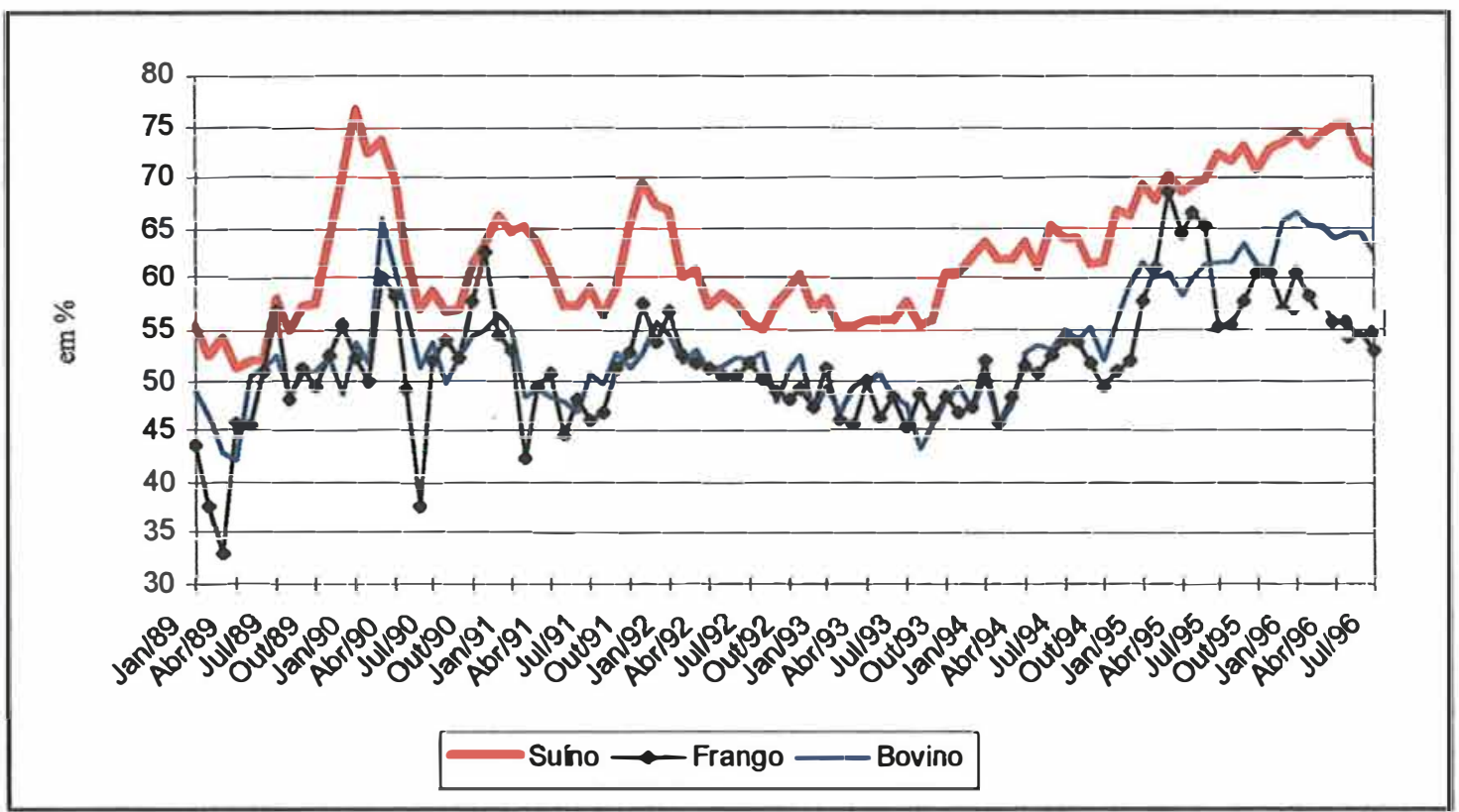

Fonte: Elaboração do autor com dados do IEA

Figura 16 - Margens totais de comercialização das carnes em porcentagem 
De acordo com os fatores que afetam as margens, citados no quarto capítulo, pode-se dizer:

a) Quanto à caracterização do mercado, o frango possui as margens mais reduzidas. A carne bovina situa-se em patamares intermediários, enquanto a carne suína apresenta as mais elevadas margens, o que obviamente vem a prejudicar seu consumo. Acredita-se que a concentração dos grandes frigoríficos descritos na Tabela 2 contribui para essa discrepância.

b) Em se tratando de característica do produto, o frango resfriado ou congelado apresenta manuseio mais fácil do que cortes de carne suína e bovina in natura; isto faz com que suas margens possam ser mais reduzidas. Neste trabalho, as margens dos produtos embutidos não foram analisadas, pois a diversidade de marcas e qualidade dificulta o processo. Mas, certamente, se estes tivessem sido levados em consideração, suas margens seriam ainda maiores. É conveniente reafirmar que, no Brasil, como em praticamente todo o mundo, grande parte do consumo de carne suína é feita sob a forma de produtos industrializados.

c) Foi observado que as mudanças tecnológicas afetaram as margens, reduzindo as dos abatedouros e em benefício dos varejistas. Essa afirmativa corrobora o visível aumento de produtividade por parte dos frigoríficos e a elevação dos custos na apresentação do produto final, relacionados principalmente a embalagens e marketing.

A redução da participação dos produtores também está relacionada ao aumento de produtividade devido às melhorias nas áreas de genética, nutrição e manejo.

d) Por último, as características da transação demonstraram que o sistema de "quase-integração" do frango é eficiente e competitivo, enquanto que, para os suínos, não se pode dizer o mesmo. Fica claro que os sistemas de comercialização do suíno podem ser aperfeiçoados a fim de contribuir para a redução das margens. Foi sobre essa questão que se baseou o item 6.1 deste trabalho. 


\section{CONSIDERAÇÕES FINAIS}

O presente trabalho analisou a Competitividade do Sistema Agroindustrial Suinícola Brasileiro sobre dois focos: em relação à questão preço, através do estudo de margens de comercialização e à não-preço que se baseou em fundamentos da Nova Economia Institucional, mais especificamente da Teoria dos Custos de Transação, para analisar as relações contratuais entre produtores e indústrias. Sendo competitividade a capacidade de sobreviver e crescer de forma sustentável, buscou-se destacar a visão sistêmica, pois, aparentemente, os problemas não se encontram nos agentes individuais e sim em suas inter-relações. A seguir, são descritas as considerações finais pertinentes à proposição do trabalho.

- Referindo-se à NEI, para o caso específico dos suínos, foram observadas diferentes estruturas de govemança adotadas nas diversas regiões brasileiras. Isto aconteceu porque se provou que o suíno é mais específico em determinada localidade do que em outras. Esse ativo é considerado extremamente específico no Mato Grosso e de baixa especificidade no sudeste, estando ainda em estágio intermediário nos estados do sul. Deste modo, provou-se que a integração vertical é um arranjo eficiente no Mato Grosso e que o mercado e a "quase-integração" do sul do país poderiam se tornar mais eficientes ainda se alguns ajustes fossem considerados.

- Esses sugeridos ajustes seriam, de um lado, centrados na flexibilização dos rígidos arranjos contratuais que intermediam as relações entre as grandes agroindústrias e seus respectivos parceiros no sul do país. Isto representaria maior autonomia, desejável por grande parte dos produtores, e redução dos elevados custos de monitoramento e transporte por parte das agroindústrias aos seus inúmeros "integrados". 
Por outro lado, buscar introduzir contratos de longo prazo entre os suinocultores e frigoríficos, que atualmente se utilizam apenas do mercado como instrumento de comercialização de seus produtos, poderia servir para minimizar os problemas referentes às frequentes oscilações mercadológicas. Acredita-se que, deste modo, poder-se-ia alcançar uma maior eficiência sistêmica implicando um desejável ganho social, confirmando, assim, uma das hipóteses sugeridas.

- A outra hipótese foi comprovada após a exposição gráfica dos valores deflacionados dos preços e das margens das três carnes de maior consumo no Brasil. Pôde-se constatar claramente que o setor varejista é um dos gargalos da comercialização da carne suina in natura. Pressupondo custos semelhantes de manipulação entre as carnes, observou-se uma maior margem total da carne suína do que de suas concorrentes. Quando desmembrada essa margem total entre margem do atacado e do varejo, verificou-se que a discrepância encontrava-se justamente na segunda. Uma justificativa do setor é que são imputadas margens maiores para produtos de menor giro de vendas. Esse efeito leva a um encarecimento do preço final, que retrai os consumidores. Por outro lado, para manter uma desejada lucratividade absoluta, utilizam-se menores margens aos produtos de maiores volumes de venda, nos quais enquadram-se as carnes bovina e de frango. Persistindo essa prática, a carne suína entrará em um interminável ciclo vicioso em que sempre terá altos preços e baixas vendas influenciados pelas altas margens varejistas. Entretanto, esta irá perder competitividade perante suas concorrentes, que venderão sempre mais, pois terão preços relativos mais atraentes com margens cada vez menores. Portanto, uma maior interação com o setor varejista é urgente, pois somente assim esse ciclo poderá ser rompido, e, todo o sistema beneficiado.

- É importante destacar, ainda, que aproximadamente $75 \%$ da carne suína são consumidos sob a forma de produtos industrializados. Estes têm como característica deterem margens de comercialização ainda mais elevadas, exigindo maiores 
investimentos na marca e em embalagens. Esses produtos pertencem a uma classe de alimentos mais sofisticados e, por isso, consumidos por menor parcela da população. No entanto, possuem elevada elasticidade-renda da demanda, ou seja, com o aumento do poder aquisitivo, o efeito no consumo desse tipo de produto é grande ${ }^{19}$.

- $\quad$ Em se tratando de produtos industrializados, prioriza-se a venda da marca mais que o ingrediente básico de fabrico. Portanto, para estes, as agroindústrias encarregamse muito bem de desenvolver seu marketing. Por outro lado, a carne in natura continua com a má imagem perante a opinião pública, que deve ser melhor trabalhada. Este é um dos importantes fatores que não figurou nas hipóteses sugeridas, mas que merecem algum esclarecimento devido a seu destaque no sistema. Persiste a idéia de que o suíno é um animal sujo, transmissor de doenças, além de possuir carne gordurosa com altos teores de colesterol. A questão é que parte dos consumidores desconhece os grandes avanços desenvolvidos nos últimos anos e aplicados nas granjas tecnificadas que hoje predominam na produção, sejam eles de caráter nutricional, genético ou sanitário. Com essas mudanças, produz-se atualmente um suíno de alto controle sanitário, voltado para a produção exclusiva de carne magra e com índices de colesterol até mesmo inferiores ao de outras carnes. O que precisa ser feito é uma companha de esclarecimento público que deveria se iniciar com a classe médica e com especialistas em engenharia de alimentos e nutrição. Promover publicações e incentivar trabalhos científicos nessas áreas para dar maior suporte aos já elaborados são um bom começo. Após esse trabalho de base, passar-se-ia, então, ao esclarecimento do grande público consumidor com publicidade.

- $\quad$ Outro fator identificado como prejudicial, mas que também parece ter seus dias contados, é o referente à apresentação física do produto ao consumidor. Na maior parte dos balcões dos pequenos supermercados e açougues, a aparência do produto carne deixa muito a desejar. Este é, às vezes, acondicionado fora das especificações

${ }^{19}$ Ver Homem de Melo, F. (1988). 
apropriadas quanto a temperatura, embalagem e higiene, gerando má impressão e inibindo o consumo. O frango, por outro lado, está sempre refrigerado ou congelado e bem embalado, oferecendo uma imagem de limpeza. A portaria 304 do Ministério da Agricultura, descrita no final do Capítulo 3, pretende moralizar essa questão, referindose tanto à temperatura quanto à embalagem. Mas o grande entrave ainda é o enorme abate clandestino. Este, por estar totalmente na ilegalidade, não dá a importância necessária à qualidade de frio e à apresentação, prendendo-se integralmente à concorrência via preços e atingindo, em maior número, os consumidores de baixo poder aquisitivo.

- A tendência de crescimento das vendas de carnes nos super e hipermercados pode precipitar algumas das mudanças acima descritas, pois, nesses estabelecimentos, a preocupação com a apresentação é maior. Portanto, a grande concentração destes aumenta seu poder de barganha, podendo elevar ainda mais as margens varejistas.

- Há de se destacar ainda que o Brasil, por possuir todas as vantagens comparativas descritas no decorrer deste trabalho, pode vir a servir como atrativo para grandes multinacionais do setor, tanto na área de produção como na de transformação. Isto pode dar novo dinamismo à atividade como um todo, mas também pode mudar totalmente o perfil dos agentes envolvidos na atividade suinícola, vindo a significar até mesmo uma ruptura do atual sistema, o que causaria um impacto social imprevisível.

Portanto, conclui-se que todo o processo percorrido pela carne suína ainda precisa passar por algumas transformações, a fim de garantir uma maior parcela no mercado a esse produto. Neste trabalho, foram discutidos dois pontos cruciais relacionados à comercialização, esperando-se ter chegado a conclusões que possam vir a colaborar de alguma maneira para o aumento de competitividade do sistema suinícola brasileiro. Este é ainda um setor extremamente carente de estudos acadêmicos e que, 
devido à sua cada vez maior importância no agribusiness nacional, merece uma atenção mais declarada e menos marginalizada. 
ANEXOS 
Anexo A:

Produção mundial de carne suína por países (em mil toneladas equivalente-carcaça)

\begin{tabular}{lrrrrrr}
\hline Pais & 1990 & 1991 & 1992 & 1993 & $1994^{*}$ & $1995^{*}$ \\
\hline Argentina & 146,0 & 145,0 & 160,0 & 185,0 & 199,0 & - \\
Brasil & $1.150,0$ & $1.250,0$ & $1.150,0$ & $1.200,0$ & $1.300,0$ & $1.382,0$ \\
Canadá & $1.132,0$ & $1.133,1$ & $1.208,7$ & $1.192,2$ & $1.227,2$ & $1.237,5$ \\
EC & $13.528,0$ & $14.339,0$ & $14.338,0$ & $15.278,0$ & $15.147,0$ & $14.837,0$ \\
Japão & $1.555,0$ & $1.483,0$ & $1.434,0$ & $1.440,0$ & - & - \\
EUA & $6.965,0$ & $7.257,0$ & $7.817,0$ & $7.751,0$ & $7.963,0$ & $8.350,0$ \\
China & - & - & - & $29.700,0$ & $31.200,0$ & $33.200,0$ \\
Rússia & - & - & - & $2.432,0$ & $2.300,0$ & $2.100,0$ \\
Outros & & - & & $16.321,8$ & $15.663,8$ & $16.193,5$ \\
Total Mundial & - & - & - & $75.500,0$ & $76.500,0$ & $78.900,0$
\end{tabular}

Fonte: GATT; FAO; USDA

Nota: * Estimativa

Consumo mundial de carne suína por países

(em mil toneladas de carcaça em $\mathrm{kg}$ per capita)

\begin{tabular}{|c|c|c|c|c|c|c|c|}
\hline Pais & & 1990 & 1991 & 1992 & 1993 & 1994* & $1995^{*}$ \\
\hline \multirow[t]{2}{*}{ Argentina } & Total & 146,0 & 145,0 & 160,0 & 185,0 & 199,0 & \\
\hline & per capita & 4,4 & 5,3 & 5,7 & 6,4 & 6,5 & - \\
\hline \multirow[t]{2}{*}{ Brasil } & Total & $1.143,0$ & $1.100,0$ & $1.155,0$ & $1.165,0$ & $1.200,0$ & $1.224,0$ \\
\hline & per capita & $\begin{array}{r}7,9 \\
\end{array}$ & 7,5 & 7,8 & 7,7 & 7,8 & 7,8 \\
\hline \multirow[t]{2}{*}{ Canadá } & Total & 733,8 & 763,9 & 811,8 & 798,1 & 815,8 & 829,0 \\
\hline & per capita & 27,6 & 27,2 & 28,6 & 27,5 & 27,9 & 28,1 \\
\hline \multirow[t]{2}{*}{ EC } & Total & $13.025,0$ & $13.718,0$ & $13.911,0$ & $14.600,0$ & $14.377,0$ & $14.346,0$ \\
\hline & per capita & 39,8 & 39,8 & 40,2 & 42,0 & 41,2 & 40,9 \\
\hline \multirow[t]{2}{*}{ Japão } & Total & $2.073,0$ & $2.082,0$ & $2.090,0$ & $2.080,0$ & - & \\
\hline & per capita & 16,8 & 16,8 & 16,8 & 16,6 & & \\
\hline \multirow[t]{2}{*}{ EUA } & Total & $7.271,0$ & $7.438,0$ & $7.926,0$ & $7.901,0$ & $8.081,0$ & $8.472,0$ \\
\hline & per capita & 29,1 & 29,4 & 31,0 & 30,6 & 31,0 & 32,2 \\
\hline China & $\begin{array}{r}\text { Total } \\
\text { per capita }\end{array}$ & - & - & - & $28.394,0$ & $29.825,0$ & $31.800,0$ \\
\hline Rússia & $\begin{array}{r}\text { Total } \\
\text { per capita }\end{array}$ & - & - & - & $2.485,0$ & $2.470,0$ & $2.350,0$ \\
\hline
\end{tabular}

Fonte: GATT; FAO; USDA

Nota: * Estimativa 
Anexo B:

Planilha de Custos para Suinos

Jan-98

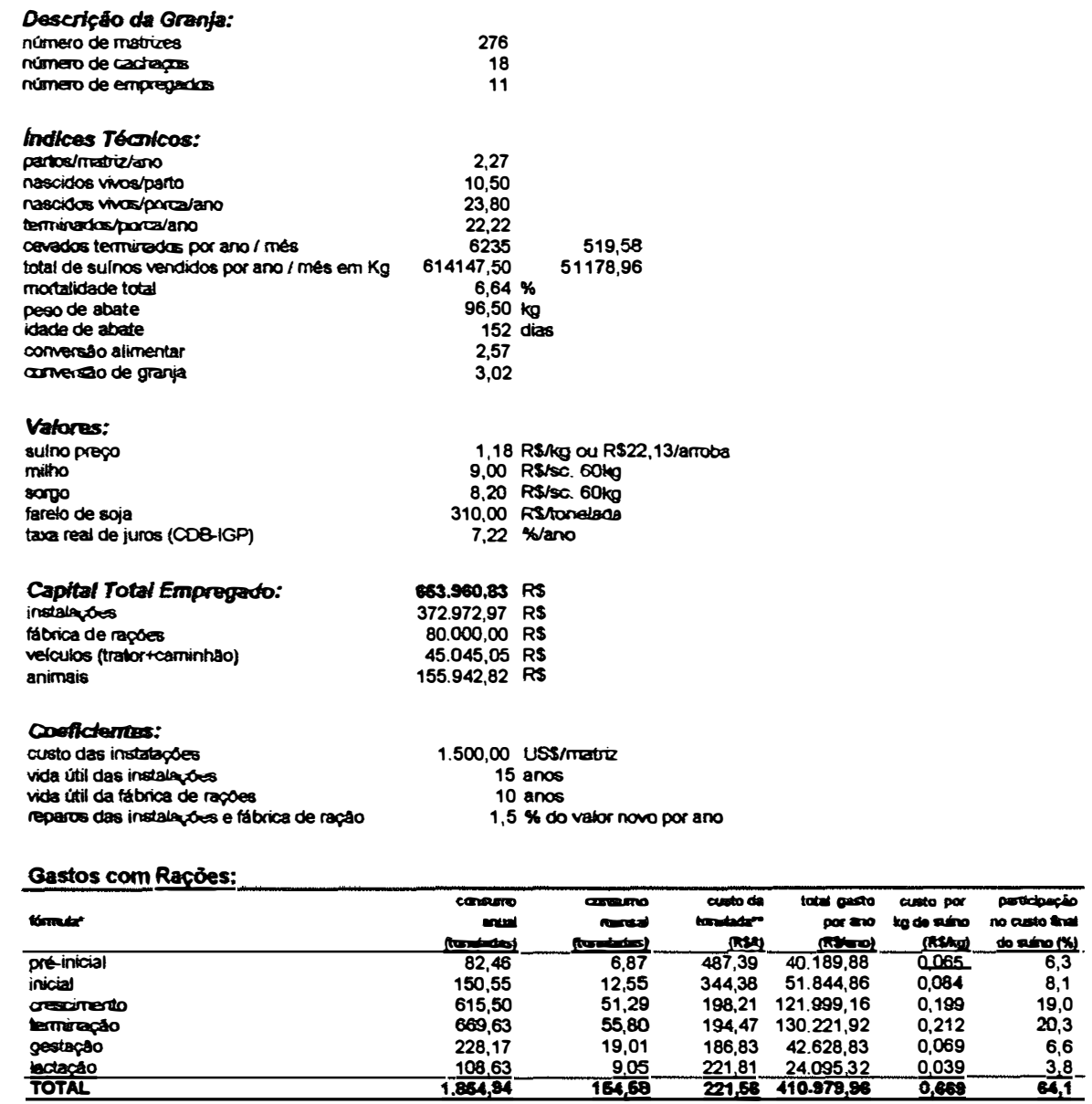

Planilha de Custos:

\begin{tabular}{|c|c|c|c|c|}
\hline Hem & 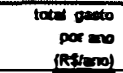 & 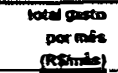 & 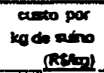 & 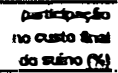 \\
\hline 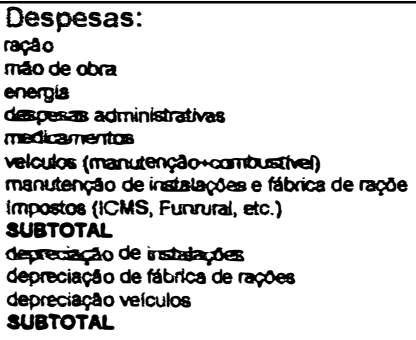 & $\begin{array}{r}410979,96 \\
73080,00 \\
15964,00 \\
9324,00 \\
23976,00 \\
8840,00 \\
8225,10 \\
47718,41 \\
688.427,46 \\
30636,00 \\
8880,00 \\
3996,00 \\
48.612,00\end{array}$ & $\begin{array}{r}34248,33 \\
6090,00 \\
1332,00 \\
777,00 \\
1998,00 \\
736,67 \\
685,43 \\
3976,53 \\
4.843,06 \\
2553,00 \\
740,00 \\
333,00 \\
3.626,00\end{array}$ & $\begin{array}{l}0,669 \\
0,119 \\
0,026 \\
0,015 \\
0,039 \\
0,014 \\
0,013 \\
0,078 \\
0,974 \\
0,050 \\
0,014 \\
0,007 \\
0,071\end{array}$ & $\begin{array}{r}64,1 \\
11,4 \\
2,5 \\
1,5 \\
3,7 \\
1,4 \\
1,3 \\
7,4 \\
23,2 \\
4,8 \\
1,4 \\
0,6 \\
6,8\end{array}$ \\
\hline TOTAL: & $641.639,48$ & $63.460,96$ & 1,045 & 100,0 \\
\hline $\begin{array}{l}\text { RECEITAS: } \\
\text { TOTAL: }\end{array}$ & $724.034,06$ & 60391,17 & & \\
\hline Resuliado do exercicio: & $83.064,67$ & 6.:21,21 & & \\
\hline
\end{tabular}

\section{Fonte: Elaboração do autor}


Anexo C:

$\frac{\text { SUINO }}{94 \mathrm{~kg}:} \longrightarrow \frac{\text { PRODUTOS DIVERSOS }}{\text { Produtos abaixo }}$

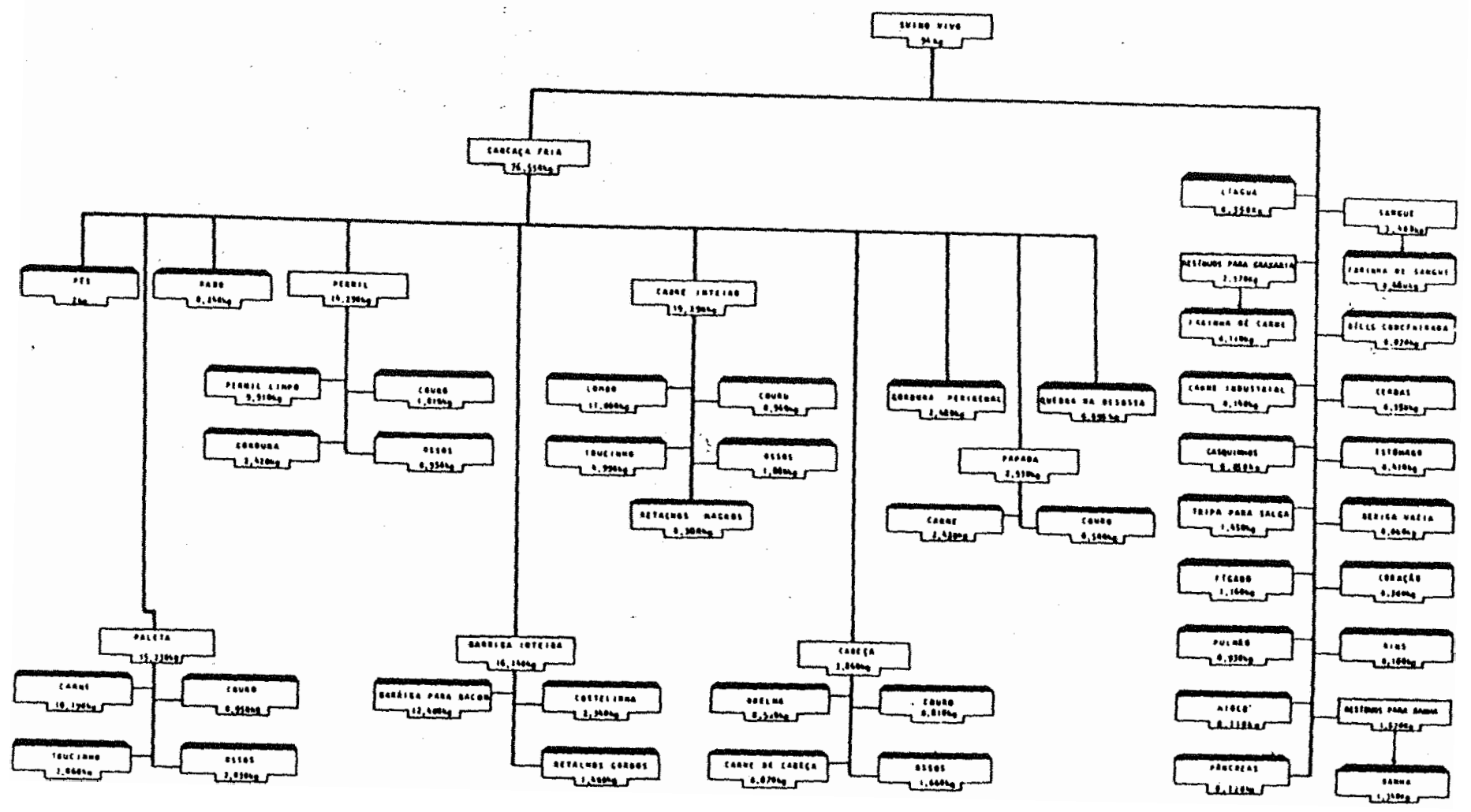

Representação dos cortes suínos e seus respectivos pesos proporcionais no animal Fonte: Canto, W.L. (1986, p.24) 
Anexo D:

Estados visitados durante o período de pesquisa:

- Santa Catarina

- São Paulo

- Minas Gerais

- Goiás

- Distrito Federal

- Mato Grosso

Empresas e entidades visitadas e entrevistadas:

- Embrapa / Suínos e Aves - Concórdia/SC

- Associação Catarinense dos Criadores de Suínos - Concórdia/SC

- Associação Mineira dos Criadores de Suínos - Belo Horizonte/MG

- Associação Brasileira dos Criadores de Suínos - São Paulo/SP

- Grupo Pão de Açúcar - São Paulo/SP

- Sadia - Concórdia/SC

- Cooperativa de Concórdia filiada à Central (Aurora) - Concórdia/SC

- Ceval - Seara/SC

- Granja Rezende - Uberlândia/MG

- Frigobet - Betim/MG

- Valentim - Distrito Federal/DF

- Comigo - Rio Verde/GO

- Agra - Rondonópolis/MT

- Intercoop - Nova Mutum/MT

- Diversos produtores em todas as regiões visitadas 


\section{REFERÊNCIAS BIBLIOGRÁFICAS}

AGUIAR, D.R.D. Formação de preços na indústria brasileira de soja-1982/1989.

Piracicaba, 1990. 140p. Dissertação (Mestrado) - Escola Superior de Agricultura Luiz de Queiroz, Universidade de São Paulo.

AZEVEDO, P.F. Integração vertical e barganha. São Paulo, 1996. 220p. Tese (Doutorado) - Faculdade de Economia e Administração, Universidade de São Paulo.

BARKEMA, A.; COOK, M.L. The changing U.S. pork industry: a dilemma for public policy. Economic Review, p.49-65, Jun. 1993.

BARROS, G.S.C. Economia da comercialização agrícola. Piracicaba : FEALQ, 1987. 306p.

BITENCOURT, M. Formação de preços e caracterização do mercado de frango em São Paulo. Piracicaba, 1996. 161p. Dissertação (Mestrado) - Escola Superior de Agricultura Luiz de Queiroz, Universidade de São Paulo.

BRIZ, J.; FILIPE, I. de. Marketing margins in food products. In: PADBERG, D.I.; RITSON, C.; ALBISU, L.M. Agro-food marketing. Chicago : CAB International, 1997. 492p.

CANTO, W.L. (Coord.) Sistema ponderal de conversões e determinação de margens de comercialização. Campinas : ITAL, 1986. 58p. (Estudos Econômicos 22). 
COASE, R.H. The firm, the market, and the law. Chicago: University of Chicago Press, 1988. 217p.: The nature of the firm.

COOK, M.F.; BREDHAL, M.E. Agribusiness competitiveness in the 1990s: discussion. American Journal of Agricultural Economics, v.73, n.5, p.1472-1473, Dec. 1991.

FARINA, E.M.M.Q. Reflexões sobre desregulamentação e sistemas agroindustriais: a experiência brasileira. São Paulo, 1996. 156p. Tese (Livre-Docência) - Faculdade de Economia e Administração, Universidade de São Paulo.

FARINA, E.M.M.Q. (Coord.) Competitividade no agribusiness. Proposta de pesquisa, São Paulo: PENSA-USP, 1997. 17p.

FARINA, E.M.M.Q.; ZYLBERSZTAJN, D. Agribusiness: coordenação das relações de conflito e cooperação. São Paulo: PENSA-USP, 1993. 56p.

FARINA, E.M.M.Q.; ZYLBERSZTAJN, D. Competitividade e organização das cadeias agroindustriais. São Paulo: FEA, 1994. 63p.

GENERAL AGREEMENT OF TARIFS AND TRADE. Les marchés internationoux de la viande: arreangement relatif a la viande bovine 1993/94. Genève, 1994. 103p.

GOLDBERG, R.A. Agribusiness coordination: a system aproach to the wheat, soybean and Florida orange economies. Boston : Harvard University, 1968.

GOMES, M.F.M. et alii. Análise prospectiva do complexo agroindustrial de suínos no Brasil. Concórdia: EMBRAPA, CNPSA, 1992. 108p. (Documento 26).

HACKENHAAR, L. Suinocultura: década de instabilidade. Preços Agrícolas, v.10, n. 110, p. 4-6, Dez. 1995. 
HOMEM DE MELO, F. Um diagnóstico sobre produção e abastecimento alimentar no Brasil. Brasília: PNUD; CDR; IPEA, 1988. 59p.

INSTITUTE TECINIQUE DU PORC. Le porc par les chiffres. Paris, 1993. 48p.

JANK, M.S. Competitividade do Agribusiness Brasileiro: discussão teórica e evidências no sistema carnes. São Paulo, 1996. 195p. Tese (Doutorado) - Faculdade de Economia e Administra, Universidade de São Paulo.

JOSKOW, P.L. Contract duration and relationship specific investments: empirical evidence from coal markets. American Economic Review, v. 17, p. 168-185, Mar. 1987.

JOSKOW, P.L. The new institutional economics: alternative approaches, concluding comments. Journal of Institutional and Theoretical Economics, v.151, n.1, p.248$259,1995$.

JUNQUEIRA, P.; CANTO, W.L. Cesta de Mercado: margens totais de comercialização. Agricultura em São Paulo, v.18, n.9-10, p.1-46, Set-Out, 1971.

KARENTININIS, K.; LAMBERT, R.; SAINT-LOUIS, R. Québec Hog/Pork industry: making new moves or simply marking time? American Journal of Agriculture Economics, v. 77 , p. 1207-1212, Dec. 1995.

KLIEBENSTEIN, J.B.; LAWRENCE, J.D. Contracting and vertical coordination in the United States pork industry. American Journal of Agriculture Economics, v. 77, p. 1213-1218, Dec. 1995.

MARQUES, P.V. Economia da integração vertical na avicultura de corte do Estado de São Paulo. Piracicaba, 1991. 133p. Tese (Livre-Docência)-Escola Superior de Agricultura Luiz de Queiroz, Universidade de São Paulo. 
MARQUES, P.V.; AGUIAR, D.R. Comercialização de produtos agrícolas. São Paulo : EDUSP, 1993. 295p.

MARTIN, L.; WESTGREN, R.; DUREN, E. VAN. Agribusiness competitiveness across national boudaries. American Journal of Agricultural Economics, v. 73, n.5, p. 1456-1464, Dec. 1991.

MASTEN, S. Empirical research in transaction cost economics: challenges, progress, directions. Mimeo, 1994. 58p.

MATTAR, F.N. Pesquisa de marketing. v.1: Metodologia, planejamento, execução, análise. São Paulo : Atlas, 1993. 350p.

MONTEVERDE, K.; TEECE, D. Suppliers swiching costs and vertical integration in the automobile industry. Bell Journal of Economics, v. 13, p. 206-213, 1982.

NORTH, D. Institutions. Journal of Economics Perspectives, v.5, n 1, p.97-112, 1991.

NORTH, D. Custos de transação, instituições e desempenho econômico. Rio de Janeiro : Instituto Liberal, 1994. 38p.

PARRÉ, J.L. Influência dos custos de comercialização e dos subprodutos sobre a margem de comercialização da carne bovina. Piracicaba, 1995. 86p. Dissertação (Mestrado) - Escola Superior de Agricultura Luiz de Queiroz, Universidade de São Paulo.

PORTER, M.E. A vantagem competitiva das nações. Rio de Janeiro : Campus, 1993. $512 \mathrm{p}$. 
RABOBANK INTERNATIONAL NETWORK. Competitiveness in the pig industry. Netherland, 1993. 64p.

RIORDAM, M.H.; WILLIAMSON, O.E. Asset specificity and economic organization. International Journal of Industrial Organization, v. 3, p. 365-378, 1985.

SCHROEDER, T.C.; MINTERT, J. Analysis of pork marketing margins. Indianapolis: National Pork Producers Council, 1996a. 33p.

SCHROEDER, T.C.; MINTERT, J. Linkages in weekly and monthly live hog, wholesale pork, and retail pork prices. Indianapolis: National Pork Producers Council, 1996b. 56p.

SMITH, A. A riqueza das nações. São Paulo : Nova Cultural, 1985. 2v. (Os Economistas).

SPOHR, P.A.; MARCHETTI, V.; ROHR, E.J. Suinocultura: importância para o Estado do Rio Grande do Sul. Porto Alegre: UFRGS, 1996. 46p.

TALAMINI, D.J.D.; GIROTTO, A.; GOMES, J.P. et al. Análise do complexo agroalimentar de suínos de Santa Catarina. Concórdia: EMBRAPA, CNPSA, versão preliminar, 1995. 68p.

WESTGREN, R.E. Firm resources, industrial organization and austrian economics: The bases for a new strategic management aproach to competitiveness. In: XXI INTERNATIONAL CONFERENCE OF AGRICULTURAL ECONOMISTS, Zimbabwe, 1994. Plenary papers.

WILLIAMSON, O.E. Markets and hierarchies. New York : The Free Press, 1975. $286 \mathrm{p}$. 
WILLIAMSON, O.E. The economic institutions of capitalism. New York : The Free Press, 1985. 449p.

WILLIAMSON, O.E. Comparative economic organization: the analysis of discrete structural alternatives. Administrative Science Quarterly, n. 36, p.269-296, 1991.

WILLIAMSON, O.E. Transaction cost economics and organization theory. Mimeo, 1993a. 68p.

WILLIAMSON, O.E. Introduction In: the nature of the firm. WILLIAMSON, O.E.; WINTER, S.G., Oxford: University Press, 1993b. 256p.

WILLIAMSON, O.E. The mechanisms of governance: prologue. Berkeley : University of California, 1994. 26p.

WORLD TRADE ORGANIZATION. The international market for meat 1994/95. Genebra, 1995. 130p.

YOTOPOULOS, P.A. Middle-income classes and food crisis: The "new" food-feed competition. Economic Development and Cultural Change, v. 33, n 3, p. 463-483, Apr. 1985.

ZYLBERZTAJN, D. Estruturas de governança e coordenação do agribusiness: uma aplicação da Nova Economia das Instituicões. São Paulo, 1995. 237p. Tese (LivreDocência) - Faculdade de Economia e Administração, Universidade de São Paulo. 


\section{APÊNDICES}




\section{Apêndice 1:}

\section{Questionários:}

\section{Ouertionário referente à obyencào de dados parn o trabatho de dissentacāo de Mestrado}

\section{Produtores de Suinos:}

Perauninas Espocticas:

1) Qual o tipo de criaça que possui?
a) Ciclo completo
b) Produtor de leitios
c) Terminador
d) Condsmino

2) Em que catogorio sua grajia se enquadracie?

Seintiried:

a) Pequeno $<30$ matrizes

b) Médio de 30 a 100 metrizes

c) Grande $>100$ matrizes

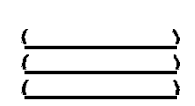

\section{Se independente:}

$<150$ matrizes

de 150 a 500 matrizes

$>500$ motrizes

3) Como vocos vende sou produto? Quem estiputs o preco? Utiliza preço de alguma botsa?

- L Nogaciando divetamente a frigorfico

- L Utilizando senvico do intermediario

- _ Faz algume programaça com algum frigortioo

- Tem algum tipo de contrato com a industria?

sDe que tipo?

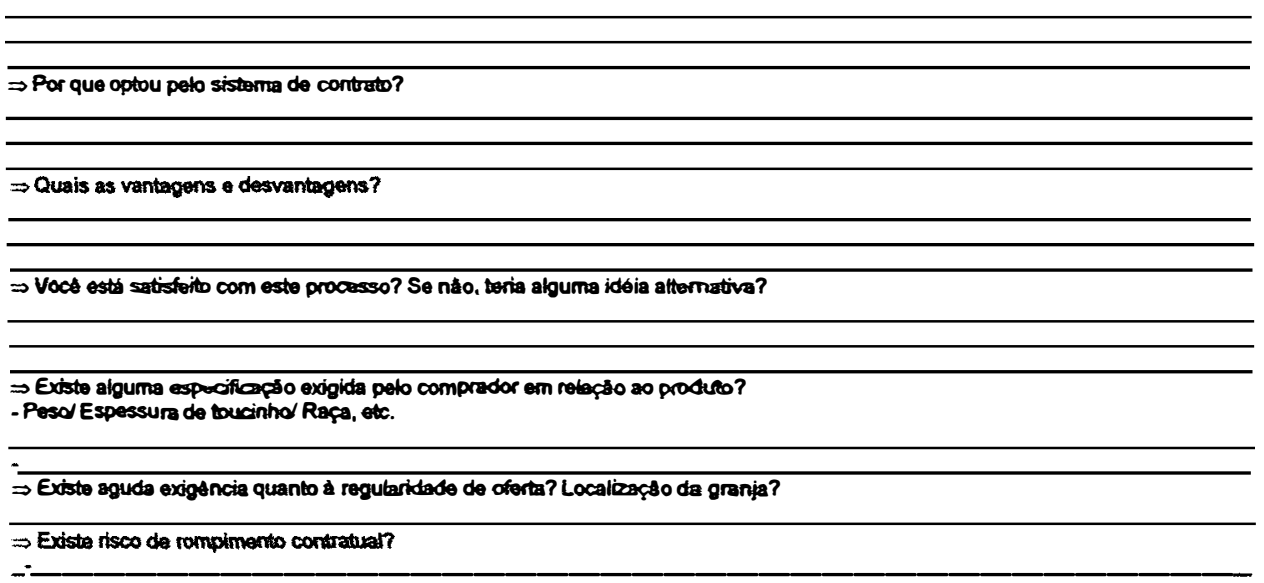

Permumas Gerais:

1) Enumere em ordem de imputancta quais seriam os problemas mais groves no Sisterna Agroindustrial Suinlcota Brasileiro?

a) De ordem reacrecoromica

( Fiscal (impostos)

$\leftrightharpoons$ Taxa de juros, etc.

(_) Falta de credito

Coutras. Quis:

b) Fontasso de preso

- Dopendente do preco estipubado pela industria.

- Diladtade en preticar o prego da botsa, se eta existir.

c) Comaciatizacto

- Ofiaddade en colocapaso do produto no mercado.

- Maskoting.

2) Voce tem muites strerretives de vende de sou prodeco? Sin ou nfo.

- Se sim: A pregos semellomtes? 
Indústrias compradoras de suinos:

\section{Perquntas especificas:}

1) Qual o número aproximedo de abate de suinos/dia?

a) Pequeno < 150 cabegas

b) Cudio de 150 a 500 cabepas

c) Grande >500 caberas

Quanto:

2) Qual a porcentagan dos animais abatidos que 6 industridizada e vendida in natura?

3) Há algum problems na aquisiço da matiria prime sulno?

$\Rightarrow$ Quanto \& qualidade?

$\Rightarrow$ Quanto a regularidade de entrega?

$\Rightarrow$ Quanto a prepo?

4) Como compra sua matteria prima? A que prepo?

4) Como compra sua matéria prima? A que prepo?

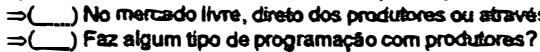

$\Rightarrow$ C Pratica algum tipo de contrato formal com produtores, integraço ou algum outro? Como funciona?

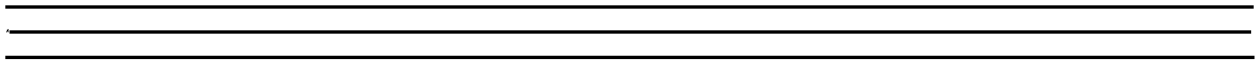

$\Rightarrow$ Esta satisteito com esto processo? Sim ou náo; Se náo, qual seria o modedo ideal para a indistria de relagáo com os produtores?

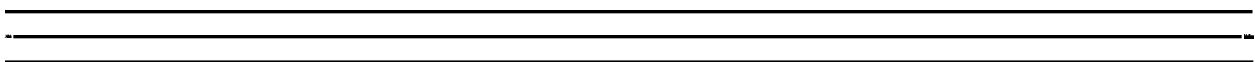

\section{Pernuntas gerpis:}

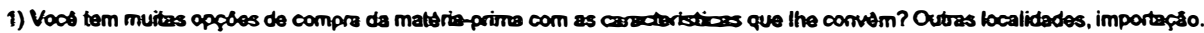

\section{2) Acha a rolagso produtor industria um gargalo no sisterna? Por que?}

3) Nos novos investimentus da empresa, qual o tipo de rolaço contratual com os produtures que a industria pretende adoeer?

-

$\Rightarrow$ Se a localieapaso e o perfil do produtor forem diferentes, mudaria alguma coisa?

$\longrightarrow$

4) Acha que as margens de comerciatizaça poderiam ser afetadas de acordo com as diferentes retaches contratuats? Em que sentido?

5) Quats as expectitives para o mercado hiternacional? 
APENDICE 2: Dados originais utilizados para elaborar as figuras 13 e 14 conseguidos, conforme descrito na metodologia

\begin{tabular}{|c|c|c|c|c|c|c|}
\hline \multicolumn{4}{|c|}{$\frac{\text { Precos des cames no varejo }}{\text { Defiacionados pelo IGP.DI }}$} & \multicolumn{3}{|c|}{ Relacão de precos das cames no varejo } \\
\hline & Bovino & Suino & Frango & Suino/Bovino & Suino/Frango & Frango/Bovino \\
\hline jan/89 & 4,85 & 6,48 & 2,93 & 1,34 & 2,21 & 0,60 \\
\hline fev/89 & 4,31 & 6,05 & 2,68 & 1,40 & 2,26 & 0,62 \\
\hline $\operatorname{mar} / 89$ & 4,18 & 6,49 & 2,62 & 1,55 & 2,48 & 0,63 \\
\hline abr/89 & 4,78 & 7,30 & 3,64 & 1,53 & 2,01 & 0,76 \\
\hline mai/89 & 6,41 & 9,43 & 4,88 & 1,47 & 1,93 & 0,76 \\
\hline jun/89 & 7,51 & 10,71 & 5,07 & 1,43 & 2,11 & 0,68 \\
\hline jul/89 & 5,68 & 8,35 & 3,46 & 1,47 & 2,41 & 0,61 \\
\hline Ago/89 & 6,53 & 6,69 & 3,28 & 1,02 & 2,04 & 0,50 \\
\hline $\operatorname{set} 89$ & 5,20 & 5,45 & 3,02 & 1,05 & 1,80 & 0,58 \\
\hline out/89 & 4,26 & 4,31 & 2,31 & 1,01 & 1,86 & 0,54 \\
\hline nov/89 & 4,91 & 5,02 & 2,56 & 1,02 & 1,96 & 0,52 \\
\hline $\operatorname{dez} / 89$ & 4,66 & 6,85 & 3,15 & 1,47 & 2,17 & 0,68 \\
\hline jan/90 & 5,72 & 5,14 & 2,84 & 0,90 & 1,81 & 0,50 \\
\hline fev/90 & 4,53 & 4,29 & 2,68 & 0,95 & 1,60 & 0,59 \\
\hline $\operatorname{mar} / s 0$ & 5,52 & 5,62 & 2,86 & 1,02 & 1,96 & 0,52 \\
\hline$a b r / 90$ & 4,84 & 5,38 & 2,38 & 1,11 & 2,26 & 0,49 \\
\hline mairso & 4,54 & 5,43 & 2,20 & 1,20 & 2,47 & 0,48 \\
\hline jun/so & 4,97 & 6,20 & 2,17 & 1,25 & 2,86 & 0,44 \\
\hline juuso & 4,93 & 6,28 & 2,93 & 1,27 & 2,14 & 0,59 \\
\hline ago/90 & 4,82 & 5,57 & 2,87 & 1,16 & 1,94 & 0,59 \\
\hline $\operatorname{set} 90$ & 5,97 & 5,80 & 3,42 & 0,97 & 1,70 & 0,57 \\
\hline out/90 & 5,51 & 5,66 & 3,20 & 1,03 & 1,77 & 0,58 \\
\hline nov/9o & 4,57 & 4,92 & 2,43 & 1,08 & 2,03 & 0,53 \\
\hline dez/90 & 4,10 & 4,60 & 2,21 & 1,12 & 2,08 & 0,54 \\
\hline jan/91 & 4,43 & 5,16 & 2,58 & 1,16 & 2,00 & 0,58 \\
\hline fev/91 & 3,95 & 5,54 & 2,38 & 1,40 & 2,33 & 0,60 \\
\hline marr91 & 3,70 & 5,43 & 2,17 & 1,47 & 2,50 & 0,59 \\
\hline abr/91 & 3,57 & 5,00 & 2,10 & 1,40 & 2,38 & 0,59 \\
\hline mais91 & 3,36 & 4,70 & 2,04 & 1,40 & 2,31 & 0,61 \\
\hline jun/91 & 3,53 & 4,80 & 2,17 & 1,36 & 2,21 & 0,61 \\
\hline julv1 & 4,25 & 5,02 & 2,08 & 1,18 & 2,41 & 0,49 \\
\hline ego/91 & 4,80 & 4,84 & 1,97 & 1,01 & 2,46 & 0,41 \\
\hline $\operatorname{set} / 91$ & 4,99 & 4,61 & 2,02 & 0,92 & 2,28 & 0,41 \\
\hline outs1 & 5,67 & 4,92 & 2,18 & 0,87 & 2,25 & 0,39 \\
\hline nov/91 & 5,42 & 5,70 & 2,50 & 1,05 & 2,28 & 0,46 \\
\hline $\operatorname{dez} / 91$ & 4,89 & 4,94 & 2,15 & 1,01 & 2,29 & 0,44 \\
\hline jan192 & 4,78 & 4,55 & 2,41 & 0,95 & 1,89 & 0,50 \\
\hline fev/92 & 4,01 & 4,04 & 2,34 & 1,01 & 1,73 & 0,58 \\
\hline mar/92 & 3,76 & 3,95 & 1,93 & 1,05 & 2,05 & 0,51 \\
\hline abrf92 & 4,12 & 3,67 & 1,76 & 0,89 & 2,09 & 0,43 \\
\hline mair92 & 4,24 & 3,96 & 2,20 & 0,93 & 1,80 & 0,52 \\
\hline jun/92 & 3,82 & 4,23 & 2,11 & 1,11 & 2,01 & 0,55 \\
\hline julv92 & 3,78 & 3,97 & 1,85 & 1,05 & 2,15 & 0,49 \\
\hline
\end{tabular}




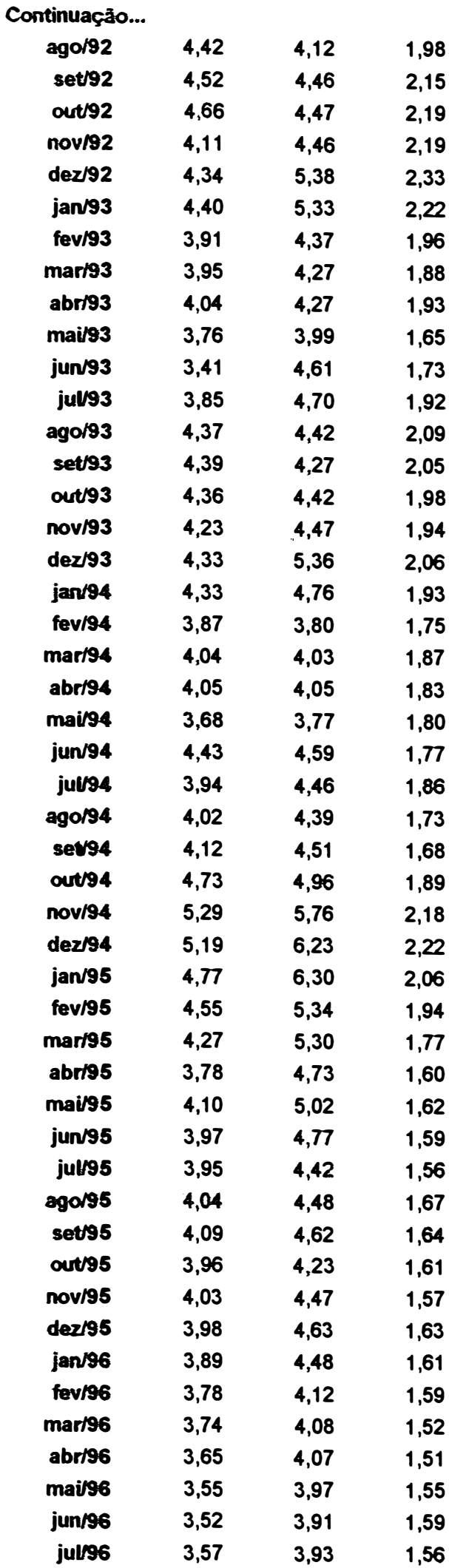

\begin{tabular}{|c|c|c|}
\hline 0,93 & 2,08 & 0,45 \\
\hline 0,99 & 2,08 & 0,48 \\
\hline 0,96 & 2,04 & 0,47 \\
\hline 1,09 & 2,04 & 0,53 \\
\hline 1,24 & 2,31 & 0,54 \\
\hline 1,21 & 2,40 & 0,51 \\
\hline 1,12 & 2,23 & 0,50 \\
\hline 1,08 & 2,27 & 0,48 \\
\hline 1,06 & 2,22 & 0,48 \\
\hline 1,06 & 2,42 & 0,44 \\
\hline 1,35 & 2,67 & 0,51 \\
\hline 1,22 & 2,44 & 0,50 \\
\hline 1,01 & 2,11 & 0,48 \\
\hline 0,97 & 2,09 & 0,47 \\
\hline 1,01 & 2,23 & 0,45 \\
\hline 1,06 & 2,31 & 0,46 \\
\hline 1,24 & 2,60 & 0,48 \\
\hline 1,10 & 2,46 & 0,45 \\
\hline 0,98 & 2,17 & 0,45 \\
\hline 1,00 & 2,16 & 0,46 \\
\hline 1,00 & 2,21 & 0,45 \\
\hline 1,03 & 2,10 & 0,49 \\
\hline 1,04 & 2,60 & 0,40 \\
\hline 1,13 & 2,40 & 0,47 \\
\hline 1,09 & 2,54 & 0,43 \\
\hline 1,10 & 2,69 & 0,41 \\
\hline 1,05 & 2,62 & 0,40 \\
\hline 1,09 & 2,64 & 0,41 \\
\hline 1,20 & 2,80 & 0,43 \\
\hline 1,32 & 3,07 & 0,43 \\
\hline 1,17 & 2,76 & 0,43 \\
\hline 1,24 & 2,99 & 0,42 \\
\hline 1,25 & 2,95 & 0,42 \\
\hline 1,23 & 3,10 & 0,40 \\
\hline 1,20 & 3,00 & 0,40 \\
\hline 1,12 & 2,84 & 0,39 \\
\hline 1,11 & 2,69 & 0,41 \\
\hline 1,13 & 2,82 & 0,40 \\
\hline 1,07 & 2,62 & 0,41 \\
\hline 1,11 & 2,84 & 0,39 \\
\hline 1,16 & 2,83 & 0,41 \\
\hline 1,15 & 2,78 & 0,42 \\
\hline 1,09 & 2,59 & 0,42 \\
\hline 1,09 & 2,68 & 0,41 \\
\hline 1,11 & 2,69 & 0,41 \\
\hline 1,12 & 2,56 & 0,44 \\
\hline 1,11 & 2,45 & 0,45 \\
\hline 1,10 & 2,53 & 0,44 \\
\hline
\end{tabular}


APÊNDICE 3: Dados originais utilizados para elaborar as figuras 15 e 16, conseguidos conforme descrito na metodologia

Suino

Frango

Boi

Mg.ata.\% Mg. var.\% Mg.total \% Mg.ata.\% Mg. var.\% Mg.total \% Mg.ata.\% Mg. var.\% Mg.total\%

\begin{tabular}{|c|c|c|c|c|c|c|c|c|c|}
\hline jan/89 & 19,65 & 35,93 & 55,57 & 27,05 & 16,39 & 43,44 & 14,01 & 34,90 & 48,91 \\
\hline fev/89 & 18,67 & 33,69 & 52,36 & 21,60 & 16,00 & 37,60 & 15,18 & 31,34 & 46,52 \\
\hline mar/89 & 15,86 & 38,41 & 54,28 & 21,26 & 11,81 & 33,07 & 13,81 & 28,82 & 42,63 \\
\hline abr/89 & 14,16 & 37,00 & 51,16 & 15,59 & 30,11 & 45,70 & 16,87 & 25,20 & 42,07 \\
\hline mai/89 & 12,96 & 38,86 & 51,82 & 14,23 & 31,32 & 45,55 & 7,82 & 42,68 & 50,50 \\
\hline jun/89 & 15,17 & 36,83 & 52,00 & 34,32 & 16,49 & 50,81 & 11,66 & 39,42 & 51,08 \\
\hline juV89 & 15,66 & 42,38 & 58,04 & 36,49 & 20,40 & 56,90 & 18,71 & 33,65 & 52,36 \\
\hline ago/89 & 8,75 & 46,35 & 55,10 & 27,33 & 20,67 & 48,00 & 12,09 & 36,40 & 48,49 \\
\hline set/89 & 9,30 & 48,03 & 57,33 & 30,50 & 20,80 & 51,30 & 14,04 & 36,56 & 50,60 \\
\hline out/89 & 8,00 & 49,65 & 57,65 & 23,66 & 25,77 & 49,43 & 14,92 & 35,88 & 50,80 \\
\hline nov/89 & 17,78 & 46,09 & 63,87 & 27,18 & 25,25 & 52,43 & 15,14 & 37,18 & 52,32 \\
\hline dez/89 & 18,59 & 51,46 & 70,05 & 34,97 & 20,50 & 55,47 & 16,24 & 32,45 & 48,69 \\
\hline jan/90 & 24,18 & 52,63 & 76,80 & 28,98 & 23,24 & 52,23 & 13,93 & 39,88 & 53,81 \\
\hline fev/90 & 19,05 & 53,34 & 72,39 & 20,07 & 29,90 & 49,97 & 13,99 & 37,62 & 51,61 \\
\hline mar/90 & 25,77 & 47,81 & 73,59 & 39,21 & 20,79 & 60,00 & 31,14 & 34,89 & 66,03 \\
\hline $\mathrm{abr} / 90$ & 16,94 & 52,90 & 69,84 & 34,70 & 23,55 & 58,25 & 21,43 & 39,09 & 60,52 \\
\hline mai/90 & 18,22 & 44,11 & 62,32 & 35,26 & 13,98 & 49,24 & 21,13 & 35,85 & 56,98 \\
\hline jur/90 & 17,21 & 39,76 & 56,97 & 30,47 & 7,23 & 37,71 & 14,46 & 36,74 & 51,20 \\
\hline jul/90 & 14,56 & 44,28 & 58,84 & 33,30 & 18,57 & 51,87 & 19,79 & 33,89 & 53,68 \\
\hline ago/90 & 10,95 & 45,88 & 56,83 & 32,96 & 20,97 & 53,93 & 17,44 & 32,19 & 49,63 \\
\hline set/90 & 8,04 & 48,89 & 56,93 & 33,27 & 19,04 & 52,30 & 16,75 & 35,62 & 52,37 \\
\hline out/90 & 7,91 & 53,44 & 61,36 & 31,19 & 26,62 & 57,81 & 17,61 & 36,94 & 54,55 \\
\hline nov/90 & 8,50 & 54,97 & 63,46 & 33,76 & 28,77 & 62,53 & 19,61 & 35,43 & 55,04 \\
\hline $\operatorname{dez} / 90$ & 10,45 & 55,83 & 66,28 & 30,67 & 23,81 & 54,48 & 19,67 & 36,81 & 56,48 \\
\hline jan/91 & 33,07 & 31,75 & 64,82 & 27,05 & 25,80 & 52,85 & 17,82 & 37,26 & 55,08 \\
\hline fev/91 & 19,12 & 46,13 & 65,25 & 26,77 & 15,50 & 42,26 & 18,06 & 30,31 & 48,37 \\
\hline mar/91 & 18,95 & 44,76 & 63,71 & 34,50 & 14,90 & 49,40 & 17,16 & 32,06 & 49,22 \\
\hline$a b r / 91$ & 14,19 & 46,74 & 60,93 & 29,38 & 21,39 & 50,76 & 18,13 & 30,12 & 48,25 \\
\hline mai/91 & 11,81 & 45,48 & 57,29 & 30,83 & 13,79 & 44,62 & 16,51 & 31,26 & 47,77 \\
\hline jun/91 & 12,10 & 45,27 & 57,37 & 31,66 & 16,45 & 48,11 & 18,15 & 28,80 & 46,95 \\
\hline juV91 & 10,73 & 48,41 & 59,14 & 30,72 & 15,38 & 46,10 & 18,02 & 32,75 & 50,77 \\
\hline ago/91 & 6,94 & 49,70 & 56,64 & 29,88 & 16,84 & 46,71 & 16,16 & 33,61 & 49,77 \\
\hline set/91 & 6,55 & 52,65 & 59,20 & 31,01 & 20,13 & 51,13 & 15,10 & 37,67 & 52,77 \\
\hline out/91 & 11,23 & 53,87 & 65,10 & 32,70 & 20,04 & 52,74 & 12,27 & 38,79 & 51,06 \\
\hline nov/91 & 15,24 & 54,30 & 69,54 & 32,83 & 24,68 & 57,51 & 13,53 & 39,11 & 52,64 \\
\hline dez/91 & 11,68 & 55,60 & 67,27 & 28,58 & 25,10 & 53,68 & 16,54 & 39,13 & 55,67 \\
\hline jan/92 & 12,88 & 53,95 & 66,83 & 26,38 & 30,49 & 56,87 & 19,12 & 35,45 & 54,57 \\
\hline fev/92 & 13,77 & 46,31 & 60,07 & 25,45 & 27,03 & 52,48 & 18,45 & 33,29 & 51,74 \\
\hline $\mathrm{mar} / 92$ & 10,37 & 50,55 & 60,92 & 29,09 & 22,64 & 51,73 & 16,25 & 36,61 & 52,86 \\
\hline$a b r / 92$ & 8,57 & 48,62 & 57,19 & 26,58 & 24,69 & 51,28 & 15,37 & 35,59 & 50,96 \\
\hline mai/92 & 8,60 & 50,02 & 58,61 & 22,78 & 27,69 & 50,47 & 13,78 & 37,73 & 51,51 \\
\hline jun/92 & 11,02 & 46,49 & 57,51 & 28,28 & 22,17 & 50,45 & 12,85 & 39,25 & 52,10 \\
\hline ju//92 & 8,76 & 46,95 & 55,71 & 27,51 & 24,26 & 51,76 & 12,42 & 39,61 & 52,03 \\
\hline
\end{tabular}




\begin{tabular}{|c|c|c|c|c|c|c|c|c|c|}
\hline ago/92 & 9,83 & 45,16 & 54,99 & 29,37 & 20,78 & 50,15 & 15,56 & 37,25 & 52,81 \\
\hline set/92 & 6,93 & 50,71 & 57,65 & 28,31 & 20,56 & 48,87 & 13,44 & 34,53 & 47,97 \\
\hline out/92 & 4,66 & 54,44 & 59,09 & 24,60 & 23,60 & 48,20 & 11,63 & 39,56 & 51,19 \\
\hline nov/92 & 10,85 & 49,62 & 60,46 & 23,61 & 25,41 & 49,02 & 12,93 & 39,42 & 52,35 \\
\hline $\operatorname{dez} / 92$ & 19,86 & 37,08 & 56,94 & 24,25 & 23,00 & 47,25 & 7,00 & 39,76 & 46,76 \\
\hline jan/93 & 17,19 & 40,78 & 57,96 & 27,09 & 24,16 & 51,24 & 11,24 & 38,08 & 49,32 \\
\hline fev/93 & 13,43 & 42,05 & 55,49 & 21,24 & 24,93 & 46,17 & 12,72 & 34,24 & 46,96 \\
\hline mar/93 & 9,43 & 46,10 & 55,54 & 20,48 & 25,17 & 45,65 & 10,77 & 38,71 & 49,48 \\
\hline abr/93 & 11,21 & 44,70 & 55,90 & 24,88 & 24,99 & 49,87 & 8,69 & 41,31 & 50,00 \\
\hline mai/93 & 7,93 & 48,07 & 55,99 & 9,82 & 36,43 & 46,25 & 10,59 & 39,98 & 50,57 \\
\hline jun/93 & 12,11 & 43,99 & 56,10 & 31,91 & 16,44 & 48,35 & 15,99 & 32,33 & 48,32 \\
\hline juV93 & 9,11 & 48,65 & 57,76 & 32,97 & 12,37 & 45,34 & 12,23 & 35,46 & 47,69 \\
\hline ago/93 & 12,22 & 43,20 & 55,42 & 29,51 & 19,18 & 48,69 & 11,34 & 31,85 & 43,19 \\
\hline set/93 & 10,45 & 45,63 & 56,08 & 25,86 & 20,43 & 46,29 & 11,21 & 34,39 & 45,60 \\
\hline out/93 & 13,75 & 46,77 & 60,52 & 25,94 & 22,34 & 48,28 & 12,23 & 35,84 & 48,07 \\
\hline nov/93 & 11,64 & 49,01 & 60,65 & 22,28 & 24,66 & 46,95 & 10,09 & 39,41 & 49,50 \\
\hline dez/93 & 13,45 & 48,69 & 62,14 & 27,05 & 20,25 & 47,30 & 9,08 & 37,93 & 47,01 \\
\hline jan/94 & 9,88 & 53,86 & 63,74 & 32,77 & 19,23 & 52,00 & 13,84 & 36,46 & 50,30 \\
\hline fev/94 & 7,65 & 54,14 & 61,79 & 19,24 & 26,67 & 45,91 & 7,74 & 37,84 & 45,58 \\
\hline mar/94 & 10,37 & 51,52 & 61,88 & 25,55 & 22,89 & 48,44 & 12,31 & 35,28 & 47,59 \\
\hline abr/94 & 8,25 & 55,45 & 63,70 & 28,31 & 23,22 & 51,53 & 15,89 & 36,73 & 52,62 \\
\hline mai/94 & 11,46 & 49,65 & 61,11 & 37,33 & 13,28 & 50,61 & 12,92 & 40,65 & 53,57 \\
\hline jun/94 & 10,02 & 55,11 & 65,14 & 47,17 & 5,22 & 52,39 & 13,07 & 39,89 & 52,96 \\
\hline jul94 & 9,61 & 54,32 & 63,93 & 28,15 & 25,93 & 54,07 & 14,07 & 40,84 & 54,91 \\
\hline ago/94 & 8,76 & 55,15 & 63,91 & 26,15 & 27,69 & 53,85 & 12,90 & 41,19 & 54,10 \\
\hline set94 & 10,53 & 50,87 & 61,40 & 26,56 & 25,00 & 51,56 & 15,63 & 39,62 & 55,25 \\
\hline olves & 10,08 & 51,55 & 61,63 & 23,65 & 25,68 & 49,32 & 13,93 & 38,00 & 51,93 \\
\hline nov/94 & 10,58 & 56,06 & 66,64 & 24,57 & 26,29 & 50,86 & 16,72 & 39,20 & 55,92 \\
\hline dez/94 & 15,67 & 50,60 & 66,26 & 29,61 & 22,35 & 51,96 & 18,80 & 40,77 & 59,56 \\
\hline jan/95 & 16,56 & 52,62 & 69,19 & 32,74 & 25,00 & 57,74 & 19,66 & 42,05 & 61,72 \\
\hline fev/95 & 14,13 & 53,74 & 67,87 & 27,50 & 33,75 & 61,25 & 16,86 & 43,24 & 60,10 \\
\hline mar/95 & 13,92 & 56,28 & 70,20 & 35,57 & 32,89 & 68,46 & 17,24 & 43,45 & 60,70 \\
\hline abr/95 & 15,58 & 53,07 & 68,65 & 35,51 & 28,99 & 64,49 & 20,39 & 37,91 & 58,30 \\
\hline mai/95 & 9,24 & 60,14 & 69,38 & 32,14 & 34,29 & 66,43 & 16,13 & 44,01 & 60,14 \\
\hline jun/95 & 3,17 & 66,67 & 69,83 & 27,66 & 37,59 & 65,25 & 15,36 & 46,14 & 61,50 \\
\hline jw/95 & 7,86 & 64,59 & 72,45 & 23,40 & 31,91 & 55,32 & 17,28 & 44,25 & 61,52 \\
\hline ago/95 & 10,52 & 61,07 & 71,59 & 24,84 & 30,72 & 55,56 & 19,51 & 42,21 & 61,72 \\
\hline set/95 & 2,62 & 70,48 & 73,09 & 13,42 & 44,30 & 57,72 & 9,09 & 54,25 & 63,33 \\
\hline out/95 & 9,03 & 61,82 & 70,85 & 30,61 & 29,93 & 60,54 & 18,21 & 43,21 & 61,42 \\
\hline nov/95 & 11,59 & 61,17 & 72,76 & 33,79 & 26,90 & 60,69 & 19,24 & 41,67 & 60,90 \\
\hline dez/95 & 14,34 & 59,11 & 73,46 & 28,48 & 28,48 & 56,95 & 21,72 & 44,02 & 65,74 \\
\hline jan/96 & 13,86 & 60,43 & 74,29 & 29,61 & 30,92 & 60,53 & 22,06 & 44,37 & 66,43 \\
\hline fev/96 & 6,68 & 66,50 & 73,17 & 28,48 & 29,80 & 58,28 & 21,59 & 43,73 & 65,32 \\
\hline mar/96 & 5,98 & 68,30 & 74,28 & 27,59 & 28,28 & 55,86 & 20,25 & 44,94 & 65,20 \\
\hline abr/96 & 7,10 & 67,95 & 75,05 & 26,90 & 28,97 & 55,86 & 19,86 & 44,17 & 64,03 \\
\hline mai/96 & 8,44 & 66,67 & 75,11 & 31,13 & 23,18 & 54,30 & 20,39 & 43,93 & 64,33 \\
\hline jun/96 & 11,45 & 60,52 & 71,97 & 28,03 & 26,75 & 54,78 & 18,35 & 46,11 & 64,46 \\
\hline juV96 & 10,37 & 60,97 & 71,34 & 27,10 & 25,81 & 52,90 & 18,95 & 43,60 & 62,54 \\
\hline
\end{tabular}


Mg.ata.\% Mg.var.\% Mg.total\% Mg.at.\% Mg. var.\% Mg.total\% Mgata.\% Mg.var.\% Mg.total\%

$\begin{array}{lccccccccc}\text { Mínimo } & 2,62 & 31,75 & 51,16 & 9,82 & 5,22 & 33,07 & 2,27 & 11,54 & 30,51 \\ \text { Médio } & 12,21 & 50,67 & 62,88 & 28,27 & 23,60 & 51,87 & 15,57 & 36,56 & 52,13 \\ \text { Máximo } & 33,07 & 70,48 & 76,80 & 47,17 & 44,30 & 68,46 & 31,14 & 54,25 & 66,43\end{array}$

